\title{
Estimation of De Facto Exchange Rate Regimes: Synthesis of the Techniques for Inferring Flexibility and Basket Weights
}

\author{
Jeffrey Frankel and Shang-Jin Wei
}

CID Working Paper No. 157

March 2008

(C) Copyright 2008 Jeffrey Frankel, Shang-Jin Wei, and the President and Fellows of Harvard College

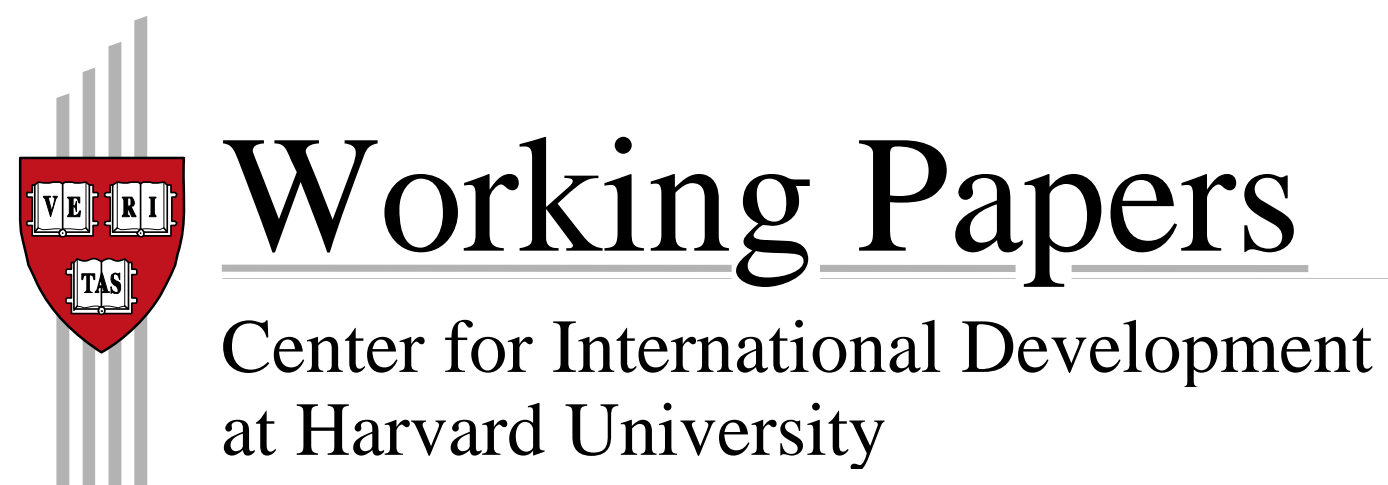




\title{
Estimation of De Facto Exchange Rate Regimes: Synthesis of The Techniques for Inferring Flexibility and Basket Weights
}

\author{
Presented at IMF Annual Research Conference \\ November 16, 2007, Washington DC
}

\author{
Jeffrey Frankel, Harvard University \\ and Shang-Jin Wei, Columbia University
}

The authors wish to thank Danxia Xie for excellent research assistance and Steve Kamin for useful comments;

and to thank the Mossavar-Rahmani Center of Business and Government and the Kuwait Fund of the Kennedy School of Government for support. Forthcoming, IMF Staff Papers, 2008

\begin{abstract}
$\underline{\text { Abstract }}$
The paper offers a new approach to estimate countries' de facto exchange rate regimes, a synthesis of two techniques. One is a technique that the authors have used in the past to estimate implicit de facto weights when the hypothesis is a basket peg with little flexibility. The second is a technique used by others to estimate the de facto degree of exchange rate flexibility when the hypothesis is an anchor to the dollar or some other single major currency, but with a possibly-substantial degree of flexibility around that anchor. Since many currencies today follow variants of Band-Basket-Crawl, it is important to have available a technique that can cover both dimensions, inferring weights and inferring flexibility. We try out the technique on twenty-some currencies, over the period 1980-2007. Most are currencies that have officially used baskets as anchors for at least part of this sample period. But a few are known floaters or known simple peggers. In general the synthesis technique seems to work as it should.
\end{abstract}

KEYWORDS: currencies, de facto, exchange rate regimes, classification, exchange market pressure, basket JEL: E42, F31

Files of data, programs and output, to aid any replication attempts, are posted at http://ksghome.harvard.edu/ jfrankel/currentpubsspeeches.htm\#On\%20Exchange\%20Rate\%20Regimes 


\title{
Estimation of De Facto Exchange Rate Regimes: Synthesis of the Techniques for Inferring Flexibility and Basket Weights
}

\author{
Jeffrey Frankel, Harvard University \\ and Shang-Jin Wei, Columbia University
}

\begin{abstract}
Exchange rate surveillance has moved back to the top of the lists of the IMF's mandates and priorities. Before one can evaluate whether a given country is following the right exchange rate regime, however, one must decide what the regime is that it is following. This seemingly simple task is far harder than one might think. Perhaps the Fund staff could use some new analytical tools if it is to pursue this assignment conscientiously and persuasively. This paper proposes a technique to classify a de facto regime. It estimates simultaneously the implicit currency weights in the basket that anchors the home currency, and the degree of flexibility around that anchor.
\end{abstract}

\section{De facto versus De Jure Classification of Exchange Rate Regimes}

It is by now well-known that there is a big difference between de facto exchange rate regimes, that is, the regimes that countries follow in practice, and de jure exchange rate regimes, that is, the regimes that national governments officially claim to be following and which, at least until 1997, were reproduced by the International Monetary Fund almost unquestioningly in the table at the front of International Financial Statistics. The discrepancy between de facto and de jure is pervasive. In the first place, most countries that claim to "fix" are not, in fact, firmly fixed. Countries declaring a peg, often abandon it. Obstfeld \& Rogoff pointed out in their 1995 article "The Mirage of Fixed Rates," that only 6 major economies (leaving aside some with capital controls) had kept a peg longer than five years. Klein and Marion (1997) reported that the mean duration of pegs in the Western Hemisphere was only 10 months.

In the second place, most countries that claim to "float," are not in fact floating. Calvo \& Reinhart (2002) coined the phrase "Fear of Floating." They showed that the variability of foreign exchange reserves relative to the variability of the exchange rate was not only substantial for those who claimed to be floating (one might expect zero for a true pure floater), but that it tended to be fully as great as for those who are officially pegging. Many emerging market countries that claim to float, sometimes under an official monetary rule of Inflation Targeting, in fact have intervened heavily in recent years to dampen the appreciation of their currencies.

In the third place, many countries that claim to be following one of the transparent intermediate regimes, namely a basket peg (or even a basket with a band), keep the weights in the basket secret. The most logical motivation is so that the government can surreptitiously depart from the official regime. When a country declares a basket peg with a band, it typically would take more than 100 observations for an observer to distinguish statistically whether it is in fact following this policy (Frankel, Schmukler \& Serven, 2000). The national authorities are no doubt aware of this when they decide to keep the basket weights secret. 
There is no more topical illustration of this problem than the Chinese yuan. The Beijing authorities announced a change in exchange rate regime in July 2005, a switch away from a dollar peg and toward a more flexible regime with reference to a basket of 11 currencies, with a small (but cumulative) band. They did not announce what were the weights on the currencies. As with so many other basket peggers, there is reason to suspect that the secrecy is not an accidental oversight. It is there deliberately to cloak a discrepancy between de jure and de facto. That the yuan is not just another currency -but lies at the heart of the disagreement to which the United States currently chooses to give top priority in its relations with China -- makes it a particularly relevant example.

There are by now many attempts to discern the true "de facto" exchange rate regimes that countries actually follow. Some of the more prominent include Shambaugh (2004), Levy-Yeyati \& Sturzenegger (2005), Ghosh, Gulde \& Wolf (2002), and Reinhart \& Rogoff $(2003,2004)$. Most of these classification schemes depart from the official classification in the direction of counting as de facto floating a country that has high variability of the exchange rate (or of the change in the exchange rate), relative to variability of reserves, and counting as fixed a country that has low variability of the exchange rate relative to reserves. A recent survey covers 11 studies. ${ }^{1} \quad$ It divided the studies into two categories, viewed as:

- "pure de facto classifications because... assignment of regimes is based solely on statistical algorithms and/or econometric estimation."

- Vs. "mixed de jure-de facto classifications, because the self-declared regimes are adjusted by the devisers for anomalies." One of the latter is the official product of the IMF's former Monetary and Exchange Affairs Department: Bubula \& OtkerRobe (2002), where the adjustment is accomplished both by consulting IMF economists and by looking at movements in reserves \& exchange rates.

While the discrepancy between the de jure regimes and any given de facto regime is well-known, it is less widely recognized that the various de facto regimes hardly correspond any more closely to each other than to the official classification. ${ }^{2}$ Table 1 reports calculations of correlations or correspondence across different classification schemes. There are various explanations for the variation in conclusions reached by the different classification schemes: differences in methodology, different choices as to where to draw the line between regimes, differences in timing of the data, and so forth. But perhaps the best way of summarizing the problem is that, apart from a relatively small number of countries that peg firmly (e.g., countries with institutional commitments in the form of currency boards) and the handful that float freely (e.g., the United States), most follow some messy intermediate regime that is not easily identified or unambiguously classified. This flies in the face of the famous "Corners Hypothesis" that rapidly became the conventional wisdom in the late 1990s, and has subsequently declined almost as rapidly. The Corners Hypothesis claimed that countries were abandoning the intermediate regimes in favor of the two corners: exchange rates fixed institutionally, as through a currency board, vs. freely floating exchange rates. But it is a fact that a

\footnotetext{
1 Tavlas, Dellas \& Stockman (2006).

2 Indeed, in the table computed by Shambaugh (2004), the correspondence among three de facto schemes tends to be lower than between each of them and the de jure scheme.
} 
majority of countries continue to follow some regime in between firm fixing and free floating. ${ }^{3}$

\section{Table 1a: Correlations Among Regime Classification Schemes}

\begin{tabular}{|c|c|c|c|c|}
\hline & IMF & GGW & LY-S & R-R \\
\hline IMF & 1.00 & & & \\
\hline GGW & 0.60 & 1.00 & & \\
\hline LY-S & 0.28 & 0.13 & 1.00 & \\
\hline R-R & 0.33 & 0.34 & 0.41 & 1.00 \\
\hline
\end{tabular}

Sample: 47 countries.

$\mathrm{IMF} \equiv$ De Jure classification from International Financial Statistics, International Monetary Fund

GGW $\equiv$ De facto classification from Ghosh, Gulde and Wolf (2002)

LY-S $\equiv$ De facto classification from Levy Yeyati and Sturzenegger (2005)

$\mathrm{R}-\mathrm{R} \equiv$ De facto classification from Reinhart and Rogoff (2004)

Source: Frankel (2004), Table 3, prepared by Marina Halac \& Sergio Schmukler.

\section{Table 1b: Correlations Among Regime Classification Schemes}

Table 5

Coefficients of correlation between 3-item regime clessifications

\begin{tabular}{|c|c|c|c|c|c|c|c|c|c|}
\hline & & \multicolumn{4}{|c|}{ Pre crisces $($ a) } & \multicolumn{4}{|c|}{ Post crises (b) } \\
\hline & & $\mathrm{BQCM}$ & LYS & IMF & $\mathrm{BOR}$ & BQCM & LYS & IMF & $\mathrm{BOR}$ \\
\hline \multirow[t]{4}{*}{ Precrises (2) } & BQCM & 1 & & & & & & & \\
\hline & LYS & 0.19 & 1 & & & & & & \\
\hline & $\mathrm{IMF}$ & 0.34 & 0.29 & 1 & & & & & \\
\hline & BOR & 0.28 & 0.26 & 0.63 & 1 & & & & \\
\hline \multirow[t]{4}{*}{ Post crises (b) } & $\mathrm{BQCM}$ & 0.24 & & & & 1 & & & \\
\hline & LYS & & 0.50 & & & 0.60 & 1 & & \\
\hline & IMF & & & 0.58 & & 0.62 & 0.69 & 1 & \\
\hline & BOR & & & & 0.55 & 0.64 & 0.65 & 0.76 & 1 \\
\hline
\end{tabular}

Soure: Author's calculations.

(a) 1994-1997 (BCCM) or 1996 (LYS, IMF, BOR).

(b) $1999-2004$ (BQCM) or 2000 (LYS, IMF, BOR).

Source: Bénassy-Quéré et al (2004).

BQCM $\equiv$ the authors' own de facto classification scheme.

LYS $\equiv$ De facto classification from Levy Yeyati and Sturzenegger

$\mathrm{IMF} \equiv$ De jure facto classification from International Monetary Fund

$\mathrm{BOR} \equiv$ De facto classification from Bubula and Otker-Robe (2003), International Monetary Fund

\footnotetext{
${ }^{3}$ Masson (2001).
} 
Table 1.c: Percentage agreement of methodologies to code who pegs

\begin{tabular}{|c|c|c|c|c|}
\hline & De Jure & Shambaugh & LY-S & R-R \\
\hline De Jure & $100 \%$ & & & \\
\hline Shambaugh & $86 \%$ & $100 \%$ & & \\
\hline LY-S & $74 \%$ & $80 \%$ & $100 \%$ & \\
\hline R-R & $81 \%$ & $82 \%$ & $73 \%$ & $100 \%$ \\
\hline
\end{tabular}

Source: Shambaugh (2004), Table A1. All codings are collapsed to binary peg and nonpeg.

One intermediate regime is the basket peg. Often it comes combined with a managed float that "leans against the wind" to push the current exchange rate back in the direction of the central parity when it wanders afield, or more specifically with an announced band (target zone). ${ }^{4}$ In any case, the weights in the basket are often kept secret, as already noted. There exists a branch of the de facto classification literature that is different from and smaller than the research on flexibility versus fixity cited above. The second approach applies especially to countries that are thought possibly to use baskets, for example because they say they do. This approach discerns from actual data the implicit weights placed on the constituent foreign currencies of the basket. The simple methodology was first developed in the early 1990s to test whether a country that announces a basket peg but does not reveal the exact weighting of the component currencies is acting in a manner consistent with its words: Frankel (1993) and Frankel and Wei $(1994,1995)$. The approach has since been used by others, including BénassyQuéré (1999), Ohno (1999), Frankel, Schmukler and Servén (2000), Frankel, Schmukler, Servén and Fajnzylber (2001) and Bénassy-Quéré, Coeuré, and Mignon (2004). ${ }^{5}$

These two branches of the literature have hitherto remained separate, in splendid isolation. It could be argued that each has its own place. If one is confident that a country is following a basket peg, and is unsure only of the weights, one should then use the weight-inference technique. If one is confident of the major anchor currency (dollar, euro, etc.) in terms of which a government defines the value of its own currency, and is

\footnotetext{
${ }^{4}$ Williamson (2001) proposes that many Asian countries should adopt combinations of baskets and bands (and perhaps crawls, which he pioneered).

${ }^{5}$ More recently, it has been applied to China's yuan: Eichengreen (2006), Shah, Zeileis, and Patnaik

(2005), Yamazaki (2006, p.8) and Frankel and Wei (2007).
} 
unsure only of the strength of the effort to stabilize, then one should use one of the methods of the larger branch of the literature, such as comparing the variability of the exchange rate (vis a vis the dollar or euro, etc.) to the variability of reserves. The problem is that some countries do define a central parity in terms of weights but then allow variation around that parity. China since 2005 is a good example of a country that claims to be doing this, and Chile in the 1990s is a good example of a country that actually did it. And even if one suspects that a country is in truth following a simple peg, it is always better to have a meaningful alternative hypothesis within which the null hypothesis is nested. Thus we want to estimate basket weights, rather than presuming we know the anchor currency, while at the same time allowing for some variation around the central parity, as in a target zone or managed floating. Hence our proposal for a synthesis of the two types of techniques in use for estimating de facto regimes.

\section{Inferring the De facto Degree of Flexibility}

It is important when inferring the de facto flexibility of an exchange rate regime to look beyond the variability of the exchange rate in itself. The korona could show a higher degree of variability than the thollar, and yet this might be because the korona has been subject to larger shocks than the thollar, rather than because the authorities intervene less and allow a given shock to show up more in the form of price movement. Thus we want to look at the variability of the exchange rate relative to the variability of foreign exchange reserves, or the monetary base, or some other monetary aggregate.

Figure 1 is a preliminary look at the data on exchange rate variability and reserve variability for 15 countries. We selected our sample to emphasize countries that claim to follow a basket peg, but added in a few that are known to be firm peggers and others that are known to be floaters, to be able to calibrate the results along the fixed-versus-floating dimension. We chose nine (small) countries that have been officially identified by the IMF as following basket pegs: Latvia, Papua New Guinea, Botswana, Vanuatu, Fiji, Western Samoa, Malta and the Seychelles. We also added several known floaters: Australia, Canada and Japan, and three peggers of special interest: Hong Kong, China and Malaysia. The paper emphasizes commodity-exporting countries, such as Norway, in our list of currencies examined, for reasons that will be obvious later. ${ }^{6}$ Variances are computed for 7-year intervals, within the period 1980-2007. The aim in choosing this length of the interval is that it be long enough to generate reliable estimates of the parameters, and yet not so long as inevitably to include important changes in each country's exchange rate regime. Here, as throughout this paper, we work with logarithmic changes in the exchange rate.

\footnotetext{
${ }^{6}$ Before any readers hear faint alarm bells about the absence of a complete or random sample, we will note that we have no need of a random or complete sample. We have no need of a random sample because, although we are testing hypotheses about individual currencies, we are not testing any general hypotheses (like all countries are at the corners). We have no need of a complete sample, because we are not attempting to offer a complete classification of IMF members as many of the other papers in the literature have done. Rather we are proposing a new technique. We have chosen to try it out on countries that we think are of interest for one reason or another.
} 
An upward-sloping line runs from the origin, and through the point representing average variance of (logarithmic change in) reserves and the average variance of (logarithmic change in) reserves. The points that lie well above this upward-sloping line represent countries that intervened actively in the foreign exchange market to stabilize their currencies during the period in question, for example, the Seychelles. The points that lie well below this upward-sloping line represent flexible-rate countries, where the authorities allow fluctuations in the demand for their currencies to show up primarily as movements in the exchange rate, for example, Japan. The downward sloping line runs through the point representing the medians of reserve variability and exchange rate variability, and is also drawn so that half the points are above and to the right of the line, and the other half are below and to the left. The points in the first category represent countries where shocks tend to be large; this tends particularly to be the case with commodity producers, such as Botswana and Papua New Guinea. The points below and to the left of the downward-sloping lines represent countries where shocks tend to be small, for example, Hong Kong. 


\section{Figure 1: Comparison of \% Reserve Variability Vs. \% Exchange Rate Variability}

\section{Currencies:}

Canadian dollar (cad), Hong Kong dollar (hkd), Malaysian ringgit (myr), Chinese yuan (cny), Japanese yen (jpy), Latvian lat (lvl), Papua New Guinea kina (png), Botswana pula (bwp), Vanuatu (vuv), Fiji dollar, Western Samoa tala (wst), Maltese lira (mtl), Seychelles rupee (scr), Norwegian kroner (nok), and Australian dollar (aud).

(Each data point represents a 7-year period, denoted in the suffix by the starting year of each period) Periods of countries with yearly inflation rate higher than $40 \%$ have been eliminated

\section{Variance of $\Delta$ Reserves vs. Variance of $\Delta$ Exchange Rate}

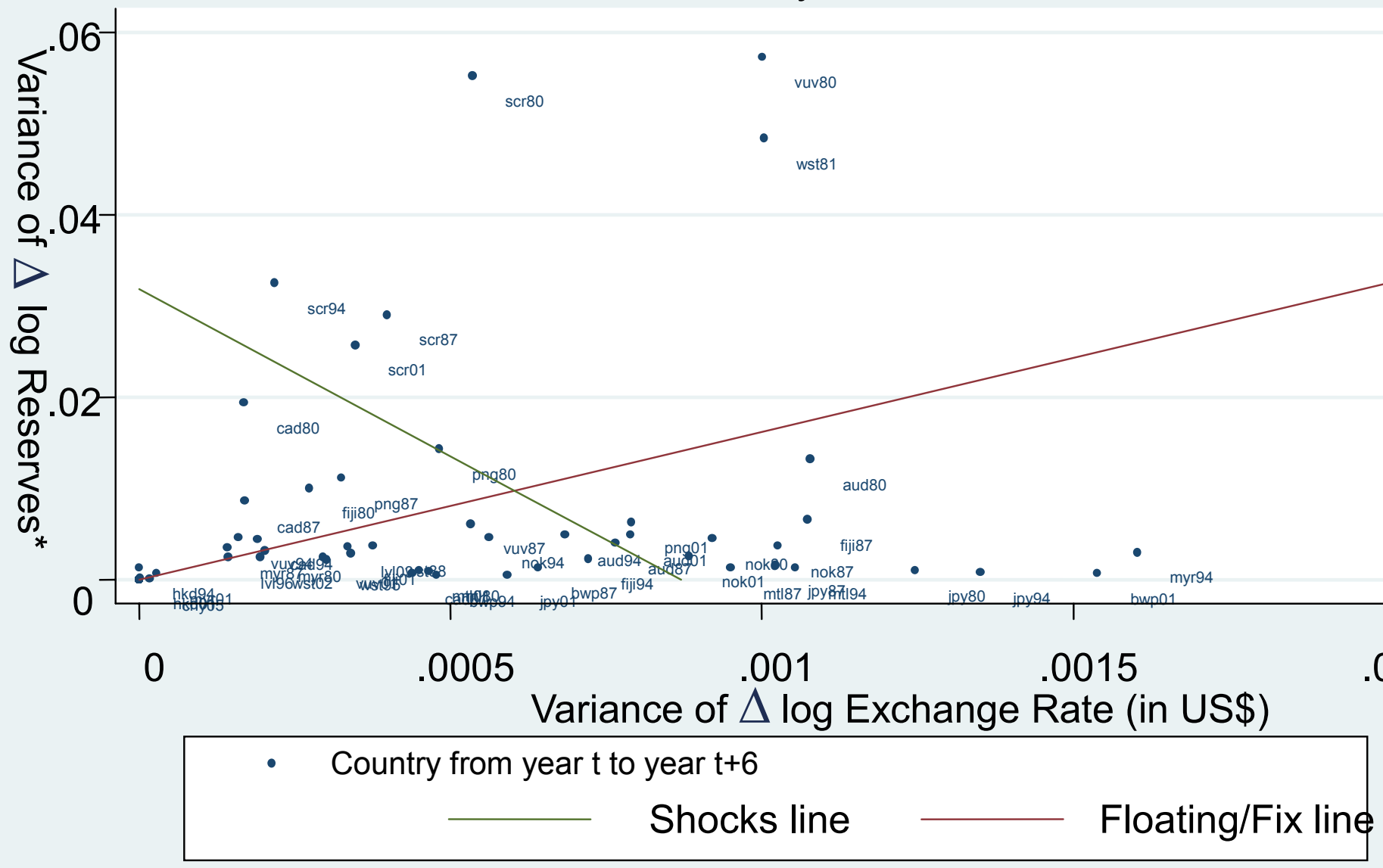

* Intervention is computed by subtracting imputed interest earnings from reported change in reserves. 
Several interesting lessons emerge from the graph, even without further analysis. The first is the folly of judging a country's exchange rate regime - specifically, the extent to which it seeks to stabilize the value of its currency - by looking simply at variation in the exchange rate. The 1980-86 Australian dollar shows a higher exchange rate variance than the 2001-07 Japanese yen. But this is not because the Australian dollar followed a more flexible exchange rate policy at that time. It is rather because Australia was hit by much larger shocks. One must focus on exchange rate variability relative to reserve variability to gauge where the country sits on the spectrum from fixed to floating. Perhaps this is obvious, but some have focused exclusively on exchange rate variability. ${ }^{7}$

The second interesting lesson to be drawn from the graph - though a less original observation than the first - is that countries that specialize in mineral products tend to have larger shocks, which presumably take the form primarily of volatility in their terms of trade. The third lesson, which was quite surprising when it was first noticed but should be familiar by now, is that even countries that float hold and use foreign exchange reserves in substantial magnitudes, sometimes more actively than countries that peg. ${ }^{8}$ An example in the graph is Canada in the 1980s. The fourth lesson is a counterpart to the third: a currency with a firm peg like the Hong Kong dollar can experience very low variability of reserves, because it has very low variability of shocks. It may in part be the absence of commodities in Hong Kong's production portfolio that makes possible the low level of shocks. But the low variability in international demand for the Hong Kong dollar must also result in part from the stability and credibility that the currency board has itself achieved. After all, Hong Kong did experience large shocks in the late 1990s - the reversion of the territory from Britain to China and the East Asia crisis - and yet the shocks do not show up in either the exchange rate or reserves. Reassuring nervous investors presumably was the goal in the first place, when the Crown Colony of Hong Kong adopted the currency board in 1983.

It is for just such reasons that the classification schemes of Calvo \& Reinhart (2002) and Levy-Yeyati \& Sturzenegger (2005) do not look at exchange rate variability alone (prices), but rather compare it to variability in reserves or money supplies (quantities). The question is: when there is a shock that increases international demand for korona, to what extent do the authorities allow it to show up as an appreciation, and to what extent as an increase in reserves. In this paper, we frame the issue in terms of the Exchange Market Pressure variable, which is defined as the percentage increase in the value of the currency plus the percentage increase in reserves (or the monetary base, or M1). ${ }^{9} \quad$ When this variable appears on the right-hand side of an equation and the percentage increase in the value of the currency appears on the left, a coefficient of 0

\footnotetext{
${ }^{7}$ Among the egregious sinners one could point to are the Frankel and Frankel-Wei papers listed in the references.

${ }^{8}$ In the early 1970s, when the international monetary system moved from fixed exchange rates to floating, the demand for international reserves did not fall as would have been predicted. Early references include Frenkel (1978) and Bilson and Frenkel (1979). Similarly, when many emerging market countries switched to more flexible exchange rate exchange rate regimes, or even to outright floating, in the currency crises of 1994-2002, the demand for reserves subsequently did not fall, but rather rose sharply (Rodrik, 2006).

${ }^{9}$ The progenitor of the Exchange Market Pressure variable, in a rather different context, was Girton and Roper (1977).
} 
signifies a completely fixed exchange rate (no changes in the value of the currency), a coefficient of 1 signifies a freely floating rate (no changes in reserves) and a coefficient somewhere in between indicates a correspondingly flexible/stable intermediate regime.

One limitation of these and other papers that estimate flexibility versus stability of exchange rate regimes is that they sometimes have to make arbitrary judgments regarding what is the major currency in terms of which flexibility and stability are to be defined. The dollar is the most common choice. This may be fine for most Western Hemisphere countries (though in fact not for Chile, and perhaps not Argentina and Brazil either). But for European countries, the euro is obviously more relevant. And for many others, particularly in Asia and the Pacific, and probably also the Middle East and parts of Africa, the relevant foreign currency is neither the dollar nor the euro, but some (possibly tradeweighted) basket. It would be better to let the data tell us what is the relevant anchor for a given country, especially for those that are not clearly in either the dollar or euro camp, rather than making the judgment subjectively or a priori. ${ }^{10}$

\section{Inferring De Facto Weights}

So, on the one hand, the main branch of the regime classification literature has the drawback that -- in its zeal to uncover the true degree of flexibility - it is unable to infer the relevant anchor. But, on the other hand, the smaller branch of the literature specializes in inferring the relevant anchor currency or basket under the null hypothesis of a perfect fit, equally omits to include anything to help make sense out of the error term under the alternative hypothesis that the country is not perfectly pegged to a major currency or to a basket. The equation is correctly specified to infer the weights in the case of a perfect basket peg, with an R2 of 1, but is on less firm ground if the authorities allow even a relatively small band of flexibility around the central parity. Thus the contribution of this paper is to bring these two branches of the literature together to produce a complete equation suitable for use in inferring de facto regimes across the spectrum of flexibility and across the array of possible anchors.

Assume that the value of the home currency is indeed determined by a currency basket. How does one then uncover the currency composition and weights in the basket? This is a problem to which Ordinary Least Squares regression is unusually well suited. If we know the list of currencies in the basket, or a list that includes as a subset those that are used in the basket, then we regress changes in the $\log$ of $\boldsymbol{H}$, the value of the home currency against changes in the log values of the candidate currencies. This technique from Frankel and Wei $(1984,1985)$ has recently been applied to the current Chinese exchange rate regime. ${ }^{11}$

\footnotetext{
${ }^{10}$ Clearly many of the authors of these papers are fully aware of the issue.

${ }^{11}$ Shah, Zeileis, and Patnaik (2005) adopted the implicit-weight methodology to study the Chinese currency basket after July 21, 2005 and found that the RMB is still tightly pegged to the dollar and nothing else. However, they only consider four candidate currencies in the RMB basket (the dollar, the yen, the euro, and the pound), probably unaware of the eleven-currency disclosure made the Chinese central bank. In addition, their sample was only the initial few months after July 21, 2005. Frankel and Wei (2006) extended to 11 the components of the basket, but found that the RMB regime in the second half of 2005 was still a tight dollar peg - as tight as that of the Hong Kong SAR regime. Eichengreen (2006, p. 22-25) had daily
} 
The reason to work in terms of changes rather than levels is the likelihood of nonstationarity. Concern for nonstationarity goes beyond the common refrain of modern time series econometrics, the inability to reject statistically a unit root, which in many cases can be attributed to insufficient power. Working in changes, we can also include a constant term to allow for the likelihood of a trend appreciation (a key question of interest in the new RMB regime) or trend depreciation (as in the crawling pegs popular in Latin American and elsewhere in the 80s), whether against the dollar alone or a broader basket. Algebraically, if the value of the home currency $\mathbf{H}$ is pegged to the values of currencies $X 1, X 2, \ldots$ and $X n$, with weights equal to $w 1, w 2, \ldots$ and $w n$, then

\section{$\log H(t+s)-\log H(t)=c+\sum w(j)[\log X(j, t+s)-\log X(j, t)]$}

If the exchange rate is truly governed by a strict basket peg, then we should be able to recover the true weights, $w(j)$, precisely, so long as we have more observations than candidate currencies, and the equation should have a perfect fit.

One methodological question, before we turn to the new synthesis estimation specification. How do we define the "value" of each of the currencies? This is the question of the numeraire. ${ }^{12}$

If the exchange rate is truly a basket peg, the choice of numeraire currency is immaterial; we estimate the weights accurately regardless. If the linear equation holds precisely in terms of any one "correct" numeraire, then add the log exchange rate between that numeraire and any arbitrary unit to see that the equation also holds precisely in terms of the arbitrary numeraire. This assumes the weights add to 1 , and there is no error term, constant term, or other non-currency variable.

In practice, few countries take their basket pegs literally enough to produce such a tight fit. One must then start to think about the nature of the error term and non-basket factors in the regression (such as the trend term), and about whether they are better measured in terms of one numeraire or another. The introduction of reserves or the exchange market pressure variable as explanatory variables should soak up some of the error term and give better estimates: by including on the right-hand side of the equation percentage changes in total exchange market pressure (defined as percentage changes in

observations of data that ran from July 22, 2005, to March 21, 2006, and found a dollar weight around .9, but with no evidence of a downward trend in the weight, and no significance on non-dollar currencies. Each of these three papers was too early to catch the evolution in 2006. Yamazaki $(2006$, p.8) updated the estimation, and found some weight had shifted to the euro, yen and won; but he estimated the equation in terms of levels rather than changes (risking non-stationarity), did not allow for a trend, did not allow for the other currencies on the list, and had a relatively small number of (bimonthly) observations. Frankel and Wei (2007) updated the estimation, ran the equation in monthly changes, included the full list of 11 candidate currencies, and allowed for gradual evolution during the sample period in both the basket weights and the trend term. We were not able to implement the present paper's methodological innovation in the case of the post-2005 RMB, because reserve data are only available monthly, and 18 observations are not enough for estimation.

12 Frankel (1993) used purchasing power over a consumer basket of domestic goods as numeraire; Frankel and Wei (1995) used the SDR; Frankel and Wei (1994, 2006), Ohno (1999), and Eichengreen (2006) used the Swiss franc; Bénassy-Quéré (1999), the dollar; Frankel, Schmukler and Luis Servén (2000), a GDPweighted basket of five major currencies; and Yamazaki (2006), the Canadian dollar. 
the value of the currency plus percentage change in reserves), the test can allow for the fluctuations in demand for the currency that can push the exchange rate away from the central basket parity. The hope is that this approach may do a better job of answering the question to what extent the authorities intervene to stabilize the currency, not just the question what is the basket in terms of which the authorities define stability.

If the true regime is more variable than a rigid basket peg, then the choice of numeraire does make some difference to the estimation. Some authors in the past have used a remote currency, such as the Swiss franc (e.g., Frankel and Wei, 1994). But a weighted index such as the SDR or a trade-weighted measure is probably more appropriate. Here is why. If the true regime is a target zone or a managed float centered around a reference basket, where the authorities intervene to an extent that depends on the magnitude of the deviation - and this seems the logical alternative hypothesis in which a strict basket peg is nested -- then the error term in the equation represents shocks in demand for the currency that the authorities allow to be partially reflected in the exchange rate (but only partially, because they intervene if the shocks are large). Then one should use a numeraire that is similar to that used by the authorities in measuring what constitutes a large deviation. The authorities are unlikely to use the Swiss franc or Canadian dollar in thinking about the size of deviations from their reference point. They are more likely to use a weighted average of major currencies. If we use a similar measure in the equation, it should help minimize the possibility of correlation between the error term and the numeraire. Similarly, if there is a trend in the exchange rate equation (a constant term in the changes equation) representing deliberate gradual appreciation of the currency, then $\boldsymbol{H}$ should be defined in terms of whatever weighted exchange rate index the authorities are likely to use in thinking about the trend. These considerations suggest a numeraire that is itself composed of a basket of currencies. We choose here the Special Drawing Right (SDR).

\section{Results of the Synthesis of Flexibility-Inference and Weight-Inference Techniques.}

$$
\begin{aligned}
& \text { Our equation is: } \\
& \begin{aligned}
\log H(t+s)-\log H(t)= & c+\sum w(j)[\log X(j, t+s)-\log X(j, t)] \\
& +\beta\{\operatorname{emp}(t+s)-\operatorname{emp}(t)\}+u_{t+s}
\end{aligned}
\end{aligned}
$$

One way to define the percentage change in total exchange market pressure ${ }^{13}$ is by $\{\operatorname{emp}(t+s)-e m p(t)\} \equiv\{\log E M P(t+s)-\log E M P(t)\}$

$$
\equiv\{[\log H(t+s)-\log H(t)]+[\log \operatorname{Res}(t+s)-\log \operatorname{Res}(t)]\} .
$$

The $w(j)$ coefficients capture the de facto weights on the constituent currencies. The coefficient $\beta$ captures the de facto degree of exchange rate flexibility : $\beta=1$ means the currency floats purely, because there is no foreign exchange market intervention (no changes in reserves) $; \beta=0$ means the exchange rate is purely fixed, because it never

\footnotetext{
${ }^{13}$ As noted, another way to define Exchange Market Pressure is by expressing the change in reserves as fraction of the level of the monetary base rather than as a fraction of the level of reserves. Such regression results are reported subsequently.
} 
changes in value ; and most currencies probably lie somewhere in between.

Endogeneity is a possible problem, and is addressed below. ${ }^{14}$

We have tried estimating the equation without imposing a constraint on the sum of the weights in the basket. But there is a good argument for constraining the weights on the currencies to add up to unity: $\sum w(j)=1$. However weak one thinks the link to the reference basket might be and however large or small the weight on the dollar, the authorities must view movements in the home currency through the metric of distance from some reference rate or effective exchange rate. There is no point throwing away the information represented by the summing-up constraint; we only have 48 observations per regression, and we need every degree of freedom we can get. The easiest way to implement the adding up constraint is to run the regressions with the changes in the log value of the home currency on the left-hand side of the equation transformed by subtracting off the changes in the log value of one of the currencies, say the British pound, and the changes in the values of the non-pound currencies on the right-hand side transformed in the same way.

To see this, we repeat equation (2), with some of the major currencies made explicit:

$$
\begin{aligned}
\log H(t+s)-\log H(t) & =c+\sum w(j)[\log X(j, t+s)-\log X(j, t)] \\
& +\beta\{\log E M P(t+s)-\log E M P(t)\}+u_{t+s} \\
= & +w(1) \Delta \log \$_{t}+w(2) \Delta \log \epsilon_{t}+w(3) \Delta \log \Psi_{t}+w(4) \Delta \log f_{t}+\ldots \\
& +\beta\{\log E M P(t+s)-\log E M P(t)\}+u_{t}
\end{aligned}
$$

We want to impose the adding up constraint $w(4)=1-w(1)-w(2)-w(3)-\ldots$ We implement it by running the regression equation (3):

$$
\begin{aligned}
& {\left[\Delta \log H_{t}-\Delta \log f_{t}\right]} \\
& =c+w(1)\left[\Delta \log \$_{t}-\Delta \log \mathfrak{f}_{t}\right]+w(2)\left[\Delta \log \epsilon_{t}-\Delta \log \mathfrak{f}_{t}\right]+ \\
& w(3)\left[\Delta \log \Psi_{t}-\Delta \log \mathfrak{f}_{t}\right]+\ldots+\beta\{\log \operatorname{EMP}(t+s)-\log \operatorname{EMP}(t)\}+u_{t}
\end{aligned}
$$

The results reported in Table 2 come from the estimation of this equation. One can recover the implicit weight on the pound by adding the estimated weights on the nonpound currencies, and subtracting the sum from 1 . This coefficient estimate is reported in the last row of the table. Imposing the constraint sharpens the estimates a bit.

Tables 2.1 through 2.21, respectively, present the individual results for 20 currencies. ${ }^{15}$ Again the currencies are those that are hypothesized to have followed a basket peg, to try out the ability of the technique to infer the weights or reject the null hypothesis, plus some clear floaters and clear peggers thrown in to calibrate the inference of flexibility.

\footnotetext{
${ }^{14}$ Estimating the regression coefficient $\boldsymbol{\beta}$ in equations (2) or (3) could be called "running on emp $\boldsymbol{t}$. "

${ }^{15} \mathrm{We}$ omit the yen and other very major currencies from the list of home countries. Such a currency is sufficiently large in world monetary markets that one cannot take the value of the other major currencies as exogenous as is necessary to estimate the weights on the right-hand side of our equation. For other smaller currencies, the assumption that the value of the dollar, euro, and other major currencies can be taken as exogenous seems reasonable.
} 
Endogeneity of the exchange market pressure variable is a possible concern. One would prefer to observe changes in the international demand for the home currency that are known to originate in exogenous shocks. In the case of countries that specialize in the production of mineral or agricultural products, there is a ready-made instrumental variable : changes in the terms of trade reflecting the price of the mineral or agricultural product on world markets. (This assumes that the home country is too small to affect the world price, which is a reasonable assumption in all but a few cases, such as Saudi Arabia and oil.) Accordingly, Table 3 repeats the synthesis estimation technique, but for the commodity producers it uses changes in the world price of the commodity in question as an instrumental variable for changes in exchange market pressure.

There is a good argument, in the definition of exchange market pressure, for computing the changes in reserves as a percentage of the monetary base, rather than as a percentage of the level of reserves itself. The problem with the latter approach is that for a country that holds relatively small levels of reserves, such as Canada and Australia, a change in reserves that is very small in absolute terms can look like a moderately large intervention in percentage terms, as we saw in Figure 1. Accordingly, on the vertical axis of Figure 2 we express reserve changes as a percentage of the monetary base, rather than as a percentage of themselves. Now Australia and Canada appear close to the bottom of the range of reserve variability where they belong, well below the upwardsloping line that demarcates the fixers from the floaters. Correspondingly, Table 4 will re-run the OLS regressions with reserve changes defined as a percentage of the monetary base.

Figure 2: Comparison of Reserve Variability versus Exchange Rate Variability Where changes in reserves are expressed as a percent of the monetary base 


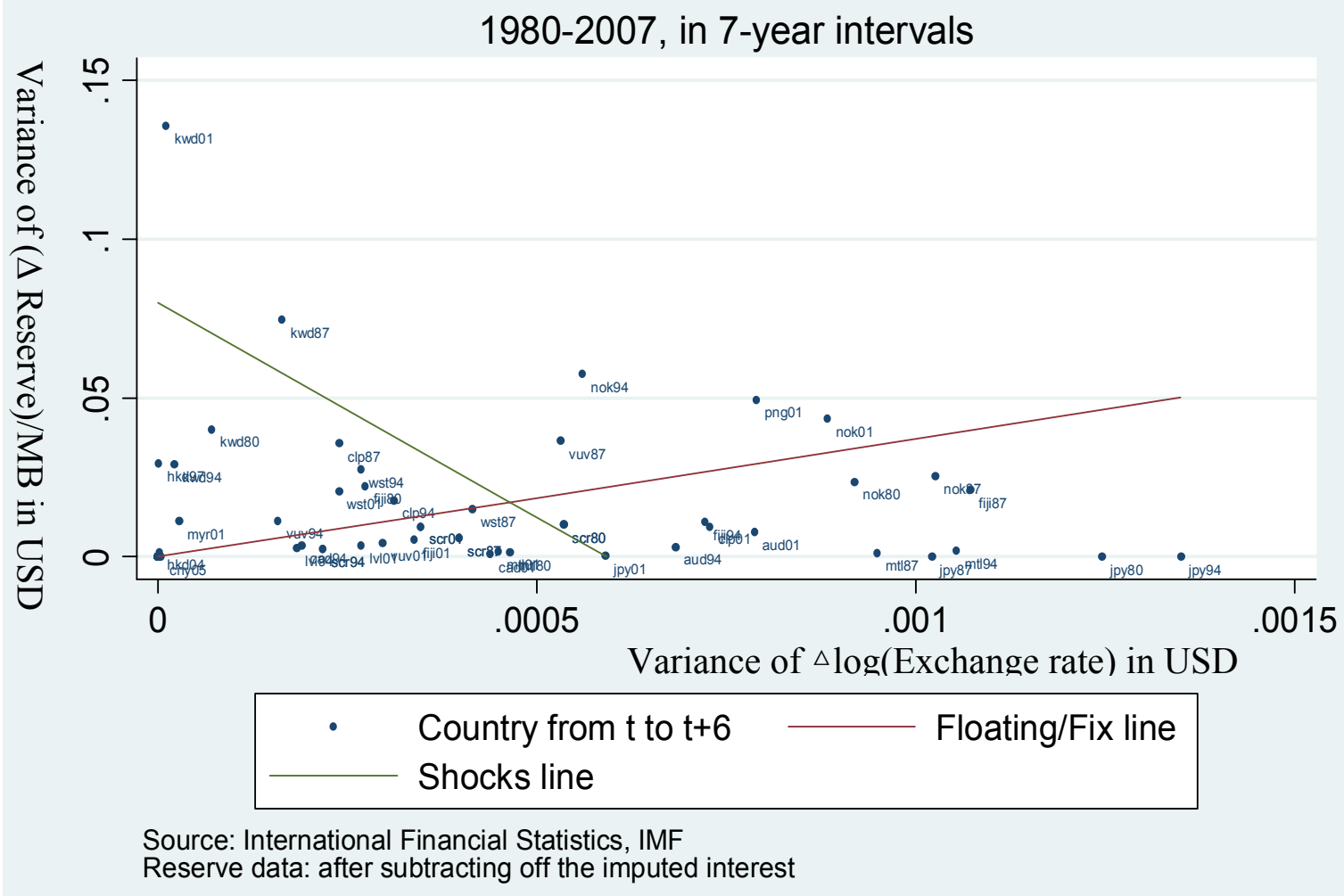

We begin with the estimated equations for three known peggers.

Table 2.1 reports the results for the Chinese yuan or RMB. It confirms earlier findings of a perfect peg to the dollar during 2001-04 (dollar coefficient $=.99$, a flexibility coefficient insignificantly different from zero, and an $\mathrm{R}^{2}$ of .99). In 2005-07 the EMP coefficient suggests that only $90 \%$ of increased demand for the currency shows up in reserves rather than $100 \%$; but the dollar weight and R2 are as high as ever.

The Hong Kong dollar is covered by Table 2.2. As one would expect given the currency board arrangement, it is a simple tight peg to the US dollar: close to complete weight on the dollar, zero flexibility, and perfect fit.

Table 2.3 refers to the Malaysian ringgit. Only in 1996-99 - the period that includes the East Asia crisis - is there evidence of exchange rate flexibility. During the years 2000-2003 there is a perfect peg to the dollar (coefficient and R2 both =1). [This confirms the danger of extreme multicollinearity if one includes the ringgit alongside the dollar as candidate components of other Asian currencies, such as the Chinese yuan.] In 2004-07 the peg is still fairly strong, but here the weight of the US dollar falls to .6, partially replaced by the Singapore dollar (with a weight of .4). Table 3.3 uses for instrumental variables the prices of tin and semiconductors (which, though a 
manufactured good, has the properties of a commodity export). The most important findings remain: a perfect dollar peg during 2000-2003, followed by shift to a basket consisting of an average of the US dollar and the Singapore dollar.

We now turn to a dozen or so countries that are considered to have pegged or anchored to a basket for at least part of the sample period.

The results for the Botswana pula are reported in Table 2.4. For 1980-87, the coefficient on EMP is essentially zero, suggesting very little exchange rate flexibility. This is the right answer, since Botswana at this time was in a monetary union with South Africa. One would have needed to use a priori knowledge to include the South African rand on the right-hand side of the equation, which we did not do, but probably should do. Botswana's exit from the currency union shows up as a large increase in the EMP variable during 1988-2007; in the current decade more than half of fluctations in the demand for the pula have been allowed to show up in the exchange rate. Botswana is officially on a basket peg. Indeed, the estimates show significant weights on the dollar (around .5 during 1988-95, but declining thereafter), and later the yen (.2), the mark or euro (.3-.6) and the pound (.2-.4), and they show R2s around .8, suggesting a semi-tight peg. There is a significant negative trend in the value of the pula throughout.

Table 2.5 applies the synthesis estimation technique to the Chilean peso. The EMP coefficient shows an intermediate degree of flexibility, consistent with the proclaimed band of the 1980s and 1990s. The combination of a basket, band and crawl seems able to explain most of the variation in the value of the peso in the $1990 \mathrm{~s}\left(\mathrm{R}^{2}>.9\right)$. The weight on the dollar is always high, but the yen also gets some weight in some years, until after 1999 when only the euro complements the dollar. There is a significant downward trend from 1980 to 1999 . Of those countries to follow a BBC (Band-BasketCrawl) regime in the 1980s and 1990s, Chile is one of the few that announced explicitly what were the parameters: basket weights, band width and rate of crawl. ${ }^{16}$ Our findings correspond to the official regime, but only rather roughly. The band was officially centered on the dollar alone in the 1980s, and was broadened to a basket starting in 1992. Our estimates qualitatively capture the shift in emphasis away from the dollar; but they find an apparently spurious weight on the yen in the mid-1980s and they miss entirely the $30 \%$ weight officially placed on the mark in the mid-1990s. Likewise, Chile officially moved to full floating in 1999. Our estimates qualitatively show the increase in the flexibility coefficient in 2000-03, but the estimates do not show the (loose) basket peg disappearing completely as the Chileans claim is the reality.

Possible explanations for the lack of a close match between the official regime and the estimates include: (1) the common disjuncture between de facto and de jure (though it is much less likely to apply here than for other countries), (2) endogeneity of the EMP variable, (3) some other shortcoming of the estimation technique, and (4) changes in the parameters that occur more frequently than the four-year sub-periods examined here. For the years since the September 1999 move to floating, (5) the failure of the flexibility coefficient to approach 1.0 might possibly have the same explanation as

${ }^{16}$ Details reported in Appendix of Frankel, Schmukler, Servén and Fajnzylber (2001). 
for Mexico: copper export earnings that add to reserves and yet are not considered by the authorities to constitute active foreign exchange intervention.

Explanation (2) can be addressed by the instrumental variables technique, for which Chile is a natural candidate since copper is half its exports. Table 3.4 uses the world copper price as the instrumental variable. At least the spurious significant coefficient on the yen in the mid-1980s disappears. But the German mark still does not make the dramatic appearance onstage in 1992-1999 that one would expect from the official announcements.

Proposition (4) may be the real explanation, and it is harder to address. The Chilean authorities announced 18 changes in regime parameters (basket weights, width of band, and rate of crawl) during the 18-year period 1982 -1999. One could imagine estimating each year separately, or matching the sub-samples to the official announcements, or using more sophisticated econometric techniques that allow endogenously-estimated breakpoints. The obstacle in all cases is that we have only monthly data, so it is not possible to estimate meaningful parameter values if they change every 12 months on average. The original Frankel-Wei technique required only exchange rate data, which allowed estimation at a daily frequency (or even intra-day). But the synthesis technique requires data on foreign exchange reserves, which are only available monthly for most countries. Indeed the attempt to estimate six or more parameters on each set of 48 observations may already be producing too much "estimation error."

Table 2.6 illustrates the Danish krone. The EMP coefficient suggests that a very high share of fluctuations in currency demand are accommodated from foreign exchange reserves. The weight on European currencies begins above .8, and rises to 1.0 with the advent of the euro in 1999 . The $\mathrm{R}^{2}$ ranges from .85 to .99 . In short the evidence is consistent with the known regime: Denmark remained behind in the $2 \frac{1 / 4}{\%}$ band, when its (non-Scandinavian) neighbors joined the euro.

Table 2.7 shows the Fiji dollar as being tightly pegged in most of the seven subperiods, with only 1984-87 and 1996-99 showing significant flexibility coefficients and R2s below .9. It is another official basket pegger. High multicollinearity between the US dollar and the Thai baht in 1988-95 prevents meaningful estimation of the coefficients during that period. (The baht should be dropped on a priori grounds.) But the weights are fairly well-estimated during the early and late years of the sample period. For the sub-period 1980-83, the US dollar receives a weight of .4, with the rest falling on the yen, Australian dollar and British pound. For the sub-period 2000-2003 they are: .2 on the US dollar, .2 on the euro, and .4 on the Australian dollar. (The New Zealand dollar should be added on a priori grounds.)

The Kuwaiti dinar shows a firm peg throughout most of the period: a near-zero flexibility parameter and R2 mostly above .9 (IV estimates in Table 3.5). In the second half of the sample, the anchor was usually a simple dollar peg, though a small weight was assigned to other currencies in the 1980s basket. In a widely watched move, the Kuwaitis in 2007 abandoned the simple dollar peg that its partners in the GCC (Gulf 
Cooperation Council) partners have been wedded to, and returned to a basket peg; but this shift is probably too recent to have had a substantial effect any of these estimates.

The Latvian lat, shown in Table 2.9, is officially on a basket peg. Here the estimation technique appears to work well. The flexibility coefficient is low during the 1990s, and has disappeared altogether since 2000. The $\mathrm{R}^{2}$ exceeds .9 during 1996-2003. The combination of low flexibility coefficient and a high $\mathrm{R}^{2}$ during 2000-2003 suggests a particularly tight basket peg during these years. Initially the estimated weights include .4 on the dollar and .3 on the yen, but both decline over time. There is a weight of .3 on the mark up until 1999, which is then transferred to the euro: .2 in 2000-2003 and .5 in 200407. Latvia is preparing to enter the eurozone. Surprisingly, however, the estimation shows a coefficient of similar size on the Russian ruble popping up during 2004-07.

The Maltese lira (Table 2.10) shows a tight peg during 1984-1991 and 2004-07 (low flexibility coefficient and high $\mathrm{R}^{2}$ ). The share of the dollar varies between .2 and .4 during 1980-2003. The European currencies garner .3-.4 during 1980-1995, the pound perhaps .2-.3 and the yen .1. At the end of the sample period, the weight on the euro rises almost to .9, with perhaps bit parts assigned to the dollar and pound. Malta is one of the ten countries that joined the EU in 2005 and one of two that join the euro in 2008.

The Norwegian krone (Table 2.11) is one of the few basket peggers in the developed world. The estimates show heavy intervention, though the R2 never crosses .8. The weights are initially .3 on the dollar and .4 on European currencies (and perhaps a little weight on the yen and pound). But the weight on the European currencies rises at the expense of the dollar, until the latter part of the sample period shows full weight on the euro and none on the dollar. Table 3.8 uses the world oil price as the instrumental variable for exchange market pressure, with results similar to OLS.

Table 2.12 refers to Papua New Guinea. In 2004-07 the flexibility coefficient for the kina falls to zero and the $\mathrm{R}^{2}$ rises to .97 , suggesting a tight peg. The peg is to the US dollar. (The only other currency ever to receive significant weight is the Australian dollar, during 1992-95.) Table 3.9 uses prices of gold, copper, oil, gas and timber as instrumental variables. The only qualitative change relative to OLS is a fall in the estimated flexibility parameters in 1996-2003

The Russian rouble (Table 2.13) shows high intervention from the beginning. There is evidence of an attempt to stabilize around the dollar during 1996-2003, but the peg is loose; this no doubt reflects both the discrete devaluation of 1998 and the band that preceded it. More recently, the rouble has acted more like a basket peg, and has assigned somewhat less weight to the dollar. In table 3.10, which uses the oil price as the instrumental variable, the flexibility parameter in the current decade drops more rapidly than under OLS.

The Seychelles rupee (Table 2.14) confirms its official classification as a basket pegger, particularly in 1984-1995: not only is the flexibility coefficient essentially zero, but the R2 exceeds .97 . The estimated weights are .4 on the dollar, .3 on the European 
currencies, . 2 on the yen, and .1 on the pound. After 2004, however, the weight on the dollar suddenly shoots up to .9 .

Table 2.15 reports the estimation for Thailand. The authorities are seen to have intervened heavily in the 1980s and 1990s. During 1988-1995 they indeed adhered to a very tight basket peg $\left(\mathrm{R}^{2}=.999\right)$. The weight on the dollar reached $.75-.88$, but there was still a significant weight of .1 on the yen. That the weight on the dollar falls short of 1.0 may come as a surprise to those who, in the wake of the Thai crisis of 1997, received the impression that the baht had been explicitly pegged to the dollar. But the official policy had been a basket peg, not a dollar peg. In the early 1990s, observers had been surprised that the estimated weight on the dollar was so high, because the earlier orthodoxy had been that Southeast Asia was rapidly becoming a yen bloc. ${ }^{17}$ The flexibility parameter rises sharply in 2000-2007, though there is still plenty of intervention. ${ }^{18}$ Table 3.11 uses the price of rice as an instrumental variable. Once again the point estimates of the flexibility parameter rise, but the significance levels fall.

Vanuatu (2.16) shows relatively low exchange rate flexibility and a fairly close fit. This is another official basket pegger. The estimates suggest roughly comparable weights on the dollar, yen, euro and pound. On a priori grounds, the Australian and New Zealand dollars ought to be added the equation.

Finally, Western Samoa (Table 2.17) shows heavy intervention during the first three sub-periods, around a basket that weights the dollar most and the yen second (and possibly the pound third). After 1992, however, there is more flexibility. The weights in the reference basket during 2000-2003 are similar to the earlier period, except that the euro now receives a large significant weight (.4). Table 3.12 uses the price of coconuts as an instrumental variable. Again flexibility parameter estimates rise, but significance levels generally fall.

We now turn to a set of floaters.

The estimated equation for the Australian dollar is reported in Table 2.18. The coefficient on Exchange Market Pressure shows a lower degree of exchange rate flexibility than one would have expected, given that the currency is thought to have floated fairly freely throughout this period. The problem may be that reserves are measured as more variable than seems right. Or the problem may be endogeneity of the Exchange Market Pressure variable. The Australian dollar is considered a commodity currency, so world commodity prices are a natural instrumental variable to correct for endogeneity. Table 3.18 reports the IV estimation for Australia. For each of the subperiods the estimated flexibility coefficient is higher than it was under OLS, but they remain surprisingly low in magnitude and statistical significance.

\footnotetext{
${ }^{17}$ Frankel (1993), Frankel and Wei (1994), and references cited therein.

${ }^{18}$ Very high multicollinearity between the US dollar and the Malaysian ringgit impedes the estimation. The won, Australiian dollar, and ringgit probably ought to be dropped on a priori grounds.
} 
As noted in the discussion of Table 2, there is a good argument, in the definition of Exchange Market Pressure, for computing the changes in reserves as a percentage of the monetary base, rather than as a percentage of the level of reserves itself. Table 4.14 uses the alternative definition of Exchange Market Pressure (EMP), with changes in reserves expressed as percentages of the Monetary Base:

$\{\operatorname{emp}(t+s)-e m p(t)\} \equiv\{[\log H(t+s)-\log H(t)]+\log [\operatorname{Res}(t+s)-\log \operatorname{Res}(t)] / M B(t)\}$. As before, a coefficient of $\beta=1$ would means that the currency floats purely, because there are no changes in reserves) and $\beta=0$ would means the exchange rate is fixed. Now the estimated coefficient and significance level on the EMP variable are higher. This tends to confirm the value of this approach, as Australia is known to be a floater. Table 5.18 applies instrumental variables to this same alternate definition of Exchange Market Pressure, but it is little changed from IV with the first EMP definition.

The Canadian dollar (Table 2.19) shows up as mostly flexible, though experiencing some intervention (the EMP coefficient ranges from .1 to .4), with the US dollar usually receiving the largest weight in the basket that the authorities are treated as implicitly using as a reference. As with Australia, the other rich commodity-exporting floater, the IV estimates show estimates of the flexibility parameter in each sub-period that are higher than they were under OLS, but that are surprisingly insignificant statistically. Again, when we switch to the alternative definition of Exchange Market Pressure, with reserve changes expressed as a percentage of the monetary base (Table 4.15), the coefficient estimates and significance levels of exchange market pressure are generally a bit higher, as is consistent with the floating nature of the Canadian dollar.

Table 2.20 looks at the Mexican peso. It shows a significant downward crawl throughout (until 2004), but it shows a peg to the dollar that is otherwise quite tight in 1988-91. Flexibility increases after the mid-point of the sample, which happens to be the peso crisis years of 1994-95. The flexibility parameter does not climb out of the range .3-.4, indicating that reserve changes have remained substantial during the latter three sub-periods, when the peso was supposedly floating. One likely explanation is that many monthly increases in reserves are associated with revenue earned by PEMEX oil exports which the authorities leave in the form of dollar deposits, but which are not conventionally considered foreign exchange intervention. Table 3.20, using the oil price as an instrumental variable, again finds flexibility parameters estimated higher, but lower in significance.

Table 2.21 reports estimation for Indonesia. The rupiah exhibits a downward trend throughout. Otherwise, the estimates show great rigidity in 1992-95, followed by a large leap in flexibility beginning in the late 1990s, at the time of the East Asia crisis. Like some other Asian countries, Indonesia's flexibility parameter comes back down in 2004-07 ("fear of floating"). Table 3.21 uses world prices of oil and natural gas as the instrumental variable, but little is learned.

\section{Extensions}


In various extensions of the basic analysis, we have also:

1. allowed coefficients to vary over time, even within the four-year sub-samples ;

2. relaxed the constraint that $\{[\log H(t+s)-\log H(t)]$ and $[\log \operatorname{Res}(t+s)-\log \operatorname{Res}(t)]\}$ enter with the same coefficient ;

3. entered the change in the interest rate alongside the change in reserves and the change in the exchange rate;

4. checked for robustness with respect to the numeraire unit used to define currency values; and

5. tried Monte Carlo studies on fabricated currencies (some constructed with the monetary authorities leaning halfway against the wind of any fluctuations in EMP, and others constrained more narrowly to remain within a 5\% band) to see if the technique is giving us the right answer.

The results in the extensions are generally in line with the results reported here. Using a different numeraire does not make too much difference, for example.

Tables 6.1-6.10 report the extension that allows the coefficients to vary over time, even within the sub-periods (extension 1, above). We expand the specification of (3) to allow for trends in level and in the currency weights :

$\left[\Delta \log H_{t}-\Delta \log f_{t}\right]=f(t)+w(1)\left[\Delta \log \$_{t}-\Delta \log f_{t}\right]+w(2)\left[\Delta \log \epsilon_{t}-\Delta \log f_{t}\right]$ $+w(3)\left[\Delta \log ¥_{t}-\Delta \log £_{t}\right]+\ldots+\beta\{\Delta \log E M P(t)\}+u_{t}$

where $\boldsymbol{f}(\boldsymbol{t})=\boldsymbol{c} \boldsymbol{0}+\boldsymbol{c} \mathbf{1} \boldsymbol{t}$. The time-dependent weight terms can be defined either using the exponential functional form for the weights $w(j)$ so that they are automatically bounded by 0 and 1 or, for simplicity, linearly: $\boldsymbol{w}(\boldsymbol{j})=\boldsymbol{b} \mathbf{0}(\boldsymbol{j})+\boldsymbol{b} \mathbf{1}(\boldsymbol{j}) * \boldsymbol{t}$.

The case of most interest is probably China (2005-2007). There is no sign in this monthly data of a downward trend in the coefficient on the dollar: the estimated trend is .000. But there is a sign that the trend in the value of the yuan itself is rising over time: since the the dependent variable is first differences, the statistically significant coefficient on " $\mathrm{t}$ " indicates an upward acceleration. The other results are as before: zero coefficients on non-dollar currencies are zero, zero coefficient on exchange market pressure, and an $\mathrm{R}^{2}$ of 1.00 , all of which indicate a simple dollar peg holding during most of this period.

Tables 7.1-7.8 relax the constraint that $\{[\log H(t+s)-\log H(t)]$ and $[\operatorname{logRes}(t+s)$ $\log \operatorname{Res}(t)]\}$ enter Exchange Market Pressure with the same coefficient (extension 2 above). The estimation takes into account that the variation of reserve changes is much larger than the variation of exchange rate changes (as can be seen in Figure 1), so that giving them equal weight means allowing the former to dominate in the estimates already reported. We define the new EMP variable as :

$$
\begin{aligned}
\Delta[\log E M P] & =\{[\operatorname{var} \Delta[\log E x] /(\operatorname{var} \Delta[\log E x]+\operatorname{Var}(\Delta[\log R e s])\} \cdot \Delta[\log R e s] \\
+ & \{\operatorname{Var}(\Delta[\log \operatorname{Res}] /(\operatorname{var} \Delta[\log E x]+\operatorname{Var}(\Delta[\log \operatorname{Res}])\} \cdot \Delta[\log E x]
\end{aligned}
$$

And $\lambda=\operatorname{var}(\Delta[\log E x]) / \operatorname{Var}(\Delta[\log \operatorname{Res}])$ 
Tables 8.1-8.5 broaden the definition of EMP another step (extension 3 above). Here the change in the interest rate is entered alongside the change in reserves and the change in the exchange rate, as three alternative ways that the authorities can respond to a change in demand for their currency (Eichengreen, Rose, and Wyplosz, 1996). We define the new EMP variable as :

$$
\begin{gathered}
\begin{array}{c}
\Delta[\log E M P]=\{\operatorname{var}(\Delta[\log E x]) / \operatorname{Var}(\Delta[\log \operatorname{Res}])\} \cdot \Delta[\operatorname{logRes}] \\
+\{\operatorname{var}(\Delta[\log E x]) / \operatorname{Var}(\Delta i)\} \cdot \Delta i \quad+\Delta[\log E x]
\end{array} \\
\begin{array}{c}
\lambda=\operatorname{var}(\Delta[\log E x]) / \operatorname{Var}(\Delta[\log R e s]) \\
\gamma=\operatorname{var}(\Delta[\log E x]) / \operatorname{Var}(\Delta[i])
\end{array} \\
\text { That is, } \Delta[\log E M P]=\lambda \cdot \Delta[\log \operatorname{Res}]+\gamma \cdot \Delta i+\Delta[\log E x]
\end{gathered}
$$

Table 9 checks whether the results are robust with respect to the choice of numeraire, by using the Swiss franc as the standard by which currencies are valued, in place of the SDR. The results are similar. The choice of numeraire does not appear to make much difference.

The last tables report results from the Monte Carlo exercises. We construct artificial exchange rate series under two regimes: managed float (Table 10.1 - 10.4) and band (Table 10.5 - 10.8). In the former case we assume that a certain percentage of any change in exchange market pressure is absorbed in reserves and the rest in the exchange rate ("leaning against the wind"). In the latter case we restrict the width of the band or target zone to plus or minus 2 and $1 / 2$ per cent. Within the band we have tried a random walk subject to the restriction that the exchange rate can't wander outside the band. One could consider other distributions. The Krugman theory of target zones provides a precise mathematical specification for the distribution within the band; but it assumes unrealistically that there is no intervention inside the band (only at the margins) and also that the band is $100 \%$ credible.

In each case we try one version where the central parity is a basket that puts $1 / 3$ weight on the dollar, $1 / 3$ on the euro and $1 / 3$ on the yen, and we try another version where the central parity is simply pegged to the dollar. In the estimation, we constrain the weights to add to 1. Although the disturbances are drawn from a random normal distribution, the magnitude (variance of the distribution) is drawn from real-world cases. We try two such cases : we take the Canadian dollar's parameters as representative of a floating currency (a low-variance reserve case), and we take Papua New Guinea's parameters as representative of a high-variance (attributable to commodity exports) small country with an intermediate regime.

In most cases, the estimates correspond well with the parameters that were built in. For example, the difference between a band with sharp borders and a policy of consistently leaning against the wind turns out to be not all that important. In every case, the estimated weights are within one or two standard errors of $1 / 3-1 / 3-1 / 3$ for the basket case, and 1 for the dollar peg case. The technique tends to pick out the correct weights even though it is not designed for the specific statistical distribution of a band. The results are especially insensitive to the choice of numeraire, as between SDR and Swiss Franc. This is reassuring, since previously we have had to rely on the a priori theorem that the choice of numeraire makes no difference in the special case of a perfect peg. 
The technique seems equally robust when estimating the parameter that represents the degree of exchange rate flexibility.

Typical $\mathrm{R}^{2} \mathrm{~s}$ tend to lie in the range .87-.89. Our conclusion is that the technique works fairly well and robustly, when the true exchange rate regime is the one assumed (in this case leaning against the wind, around either a basket or the dollar). The technique may not always work as well in practice (of which one reflection may be lower $\mathrm{R}^{2} \mathrm{~s}$ in Tables 1-9), because in practice many countries do not in fact follow a regime such as a basket band for more than a few years in a row, without devaluing or otherwise changing the parameters. To allow for changes in parameters within the sample period one would have to take the technique to the next stage of econometric sophisitication, and perhaps suffer nonetheless from data frequency insufficient to produce reliable estimates.

\section{Conclusion}

Intermediate exchange rate regimes remain alive and well. Some countries have announced basket regimes, often with an intermediate degree of flexibility that can be captured by some combination of a crawl, a band, or leaning-against-the-wind intervention. Most basket peggers keep the weights in the basket secret, which usually means they want to preserve a degree of freedom from prying eyes (whether to pursue a lower degree of de facto exchange rate flexibility, as with China, or a higher degree, as with others).

The necessary task of distinguishing de facto from de jure exchange rate regimes has produced an active recent sub-literature. But inferring de facto weights and inferring de facto flexibility are equally important, whereas most authors have hitherto done only one or the other. Thus the main contribution of this paper is to propose a synthesis specification that allows estimation of true weights at the same time as estimation of the true tendency of monetary authorities to allow exchange market pressure to show up in the price, versus the quantity, of foreign exchange.

We have tried out the technique on some 20 currencies. The majority are countries reported by the IMF to have declared the use of baskets. But we have also included some floaters and some simple peggers. For the most part the synthesis technique seems to work as it should. Known floaters tend to score much higher flexibility parameters than known peggers, with the BBC countries in between. In some cases, the inferred behavior differs in some way from the de jure regime. For example China's "basket" puts more weight on the dollar than the impression given by the government, while other declared basket peggers are not as firmly tied to the basket as they claim. Meanwhile, declared floaters often intervene heavily to dampen exchange rate fluctuations (fear of floating), but sometimes with reference to an anchor that is not a simple dollar parity as other authors may have assumed. 


\section{References}

Bénassy-Quéré, Agnès, 1999, "Exchange Rate Regimes and Policies: An Empirical Analysis," in Exchange Rate Policies in Emerging Asian Countries, edited by Stefan Collignon, Jean Pisani-Ferry, and Yung Chul Park (Routledge: London), 40-64.

Bénassy-Quéré, Agnès, Benoit Coeuré, and Valérie Mignon, 2004, "On the Identification of de facto Currency Pegs,” Journal of Japanese and International Economies.

Bilson, John, and Frenkel, Jacob, 1979, "Dynamic Adjustment and the Demand for International Reserves," NBER Working Paper No. 407, November.

Bubula, Andrea, and Inci Otker-Robe, 2003, Exchange Arrangements and Foreign Exchange Markets: Development and Issues, Monetary and Exchange Affairs Department, IMF.

Calvo, Guillermo, and Carmen Reinhart, 2002, "Fear of Floating," Quarterly Journal of Economics, 117, no. 2, May, 379-408.

Eichengreen, Barry, 2006, "China's Exchange Rate Regime: The Long and Short of It," revision of paper for Columbia University's conference on Chinese money and finance held in New York on February 2-3.

Eichengreen, Barry, Andy Rose and Charles Wyplosz, 1996, "Contagious Currency Crises," NBER WP 5681. Revised March 1997. Part of this paper was published in the Scandinavian Journal of Economics 98, 1996.

Frankel, Jeffrey, 1993, "Is Japan Creating a Yen Bloc in East Asia and the Pacific?" in Regionalism and Rivalry: Japan and the U.S. in Pacific Asia, edited by Jeffrey Frankel and Miles Kahler, University of Chicago Press, Chicago, 53-85.

Frankel, Jeffrey, Eduardo Fajnzylber, Sergio Schmukler, and Luis Servén, 2001, "Verifying Exchange Rate Regimes," Journal of Development Economics, vol. 66, no. 2, December: 351-386.

Frankel, Jeffrey, Sergio Schmukler and Luis Servén, 2000, "Verifiability and the Vanishing Intermediate Exchange Rate Regime," Brookings Trade Forum 2000, edited by Susan Collins and Dani Rodrik (Brookings Institution, Washington DC).

Frankel, Jeffrey, and Shang-Jin Wei, 1994, "Yen Bloc or Dollar Bloc? Exchange Rate Policies of the East Asian Economies," in Macroeconomic Linkages: Savings, Exchange Rates and Capital Flows, Takatoshi Ito and Anne O. Krueger, eds., Chicago: University of Chicago Press, 295-329.

Frankel, Jeffrey, and Shang-Jin Wei, 1995, "Emerging Currency Blocs," The International Monetary System: Its Institutions and its Future, Hans Genberg, ed., Springer, Berlin, 111-143.

Frankel, Jeffrey, and Shang-Jin Wei, 2007, “Assessing China’s Exchange Rate Regime,“ Economic Policy.

Frenkel, Jacob, 1978, "International Reserves Under Alternative Exchange Rate Regimes and Aspects of The Economics of Managed Float," NBER Working Paper No. 287, October.

Ghosh, Atish, Anne-Marie Gulde, and Holger Wolf, 2002, "Currency Boards: More than a Quick Fix?" Economic Policy, 31 (October): 270-335.

Girton, Lance and Don Roper, 1977, “A Monetary Model of Exchange Market Pressure Applied to the Postwar Canadian Experience," American Economic Review 67, 4 (September): 537-48. 
Klein, Michael W. \& Marion, Nancy P., 1997. "Explaining the duration of exchange-rate pegs," Journal of Development Economics, Elsevier, vol. 54(2), pages 387-404, Dec.

Levy-Yeyati, Eduardo, and Federico Sturzenegger, 2003, "To Float or to Trail: Evidence on the Impact of Exchange Rate Regimes," American Economic Review, 93, No. 4, September.

Masson, Paul R., 2001, "Exchange Rate Regime Transitions," Journal of Development Economics, Elsevier, vol. 64(2), pages 571-586, April.

Ohno, Kenichi, 1999, "Exchange Rate Management in Developing Asia," Working Paper No.1. (January), Asian Development Bank Institute.

Reinhart, Carmen, and Kenneth Rogoff, 2004, "The Modern History of Exchange Rate Arrangements: A Reinterpretation." Quarterly Journal of Economics, 119(1):1-48.

Rodrik, Dani, "The Social Cost of Foreign Exchange Reserves" (January 2006). CEPR Discussion Paper No. 5483.

Shah, Ajay, Achim Zeileis, and Ila Patnaik, 2005, "What is the New Chinese Currency Regime?" Unpublished, November.

Shambaugh, Jay, 2004, “The Effect of Fixed Exchange Rates on Monetary Policy,” Dartmouth College; forthcoming, Quarterly Journal of Economics.

G.Tavlas, H.Dellas \& A. Stockman, 2006, "The Classification and Performance of Alternate ExchangeRate Systems," March 2006, Bank of Greece.

Williamson, John, 2001, "The Case for a Basket, Band and Crawl (BBC) Regime for East Asia," in David Gruen and John Simon, eds., Future Directions for Monetary Policies in East Asia, Reserve Bank of Australia, July, 97-109.

Yamazaki, Kazuo, 2006, "Inside the Currency Basket," Columbia University and Mitsubishi UFJ Trust and Banking Corp., December. 


\section{Appendix 1}

\section{Table 2: Estimating the De Facto Exchange Rate Regime with Basic Setup}

Parameters to be estimated: Implicit weights in basket and degree of flexibility $(01 / 1980-06 / 2007)$

(Values of all currencies are measured in terms of numeraire currency $=$ SDR)

\subsection{Chinese yuan (cny)}

\begin{tabular}{|l|l|l|}
\hline & $(1)$ & $(2)$ \\
\hline & cny 01-04 & $05-08$ \\
\hline USD & $.987917 * * *$ & $1.055^{* * *}$ \\
\hline JPY & $(0.0231488)$ & $(0.110)$ \\
\hline & -0.0058267 & 0.039 \\
\hline KRW & $(0.0090792)$ & $(0.035)$ \\
\hline & & 0.061 \\
\hline SGD & & $(0.051)$ \\
\hline & & -0.163 \\
\hline MYR & & $(0.104)$ \\
\hline & & 0.025 \\
\hline RUB & & $(0.042)$ \\
\hline & & -0.131 \\
\hline AUD & & $(0.146)$ \\
\hline & & 0.026 \\
\hline THB & & $(0.026)$ \\
\hline & & 0.036 \\
\hline CAD & & $(0.048)$ \\
\hline & & -0.052 \\
\hline Euro & & $(0.031)$ \\
\hline & 0.0539523 & 0.080 \\
\hline$\Delta$ [logRes+logEx] & $(0.0524937)$ & $(0.081)$ \\
\hline & 0.0349175 & $0.106 *$ \\
\hline Constant & $(0.0382657)$ & $(0.051)$ \\
\hline & -0.0005595 & 0.000 \\
\hline Observations & $(0.0007976)$ & $(0.002)$ \\
\hline R-squared & 48 & 23 \\
\hline & 0.9859 & 0.995 \\
\hline & -0.036043 & 0.024 \\
\hline & & \\
\hline & & \\
\hline & & \\
\hline & & \\
\hline & & \\
\hline & & \\
\hline & & \\
\hline
\end{tabular}

\subsection{Hong Kong dollar (hkd)}

\begin{tabular}{|l|l|l|l|}
\hline & $(1)$ & $(2)$ & $(3)$ \\
\hline & $97-00$ & $01-04$ & $05-08$ \\
\hline JPY & -0.000 & -0.005 & -0.007 \\
\hline & $(0.003)$ & $(0.011)$ & $(0.021)$ \\
\hline USD & $0.987^{* * *}$ & -326.832 & $1.010^{* * *}$ \\
\hline & $(0.016)$ & $(334.373)$ & $(0.039)$ \\
\hline KRW & 0.003 & 0.001 & 0.007 \\
\hline & $(0.003)$ & $(0.014)$ & $(0.029)$ \\
\hline SGD & 0.003 & -0.021 & 0.020 \\
\hline & $(0.009)$ & $(0.022)$ & $(0.049)$ \\
\hline AUD & 0.004 & -0.003 & 0.023 \\
\hline
\end{tabular}




\begin{tabular}{|l|l|l|l|}
\hline & $(0.008)$ & $(0.006)$ & $(0.020)$ \\
\hline MYR & -0.005 & 327.834 & -0.009 \\
\hline THB & $(0.005)$ & $(334.370)$ & $(0.034)$ \\
\hline & -0.002 & 0.018 & -0.024 \\
\hline German mark & $(0.005)$ & $(0.018)$ & $(0.031)$ \\
\hline & -0.003 & & \\
\hline$\Delta[\operatorname{logRes}+\operatorname{logEx}]$ & $(0.008)$ & & \\
\hline & 0.001 & $-0.027^{*}$ & -0.018 \\
\hline Euro & $(0.005)$ & $(0.014)$ & $(0.032)$ \\
\hline & & -0.004 & -0.003 \\
\hline Constant & & $(0.010)$ & $(0.033)$ \\
\hline & -0.000 & -0.000 & -0.000 \\
\hline Observations & $(0.000)$ & $(0.000)$ & $(0.000)$ \\
\hline R-squared & 23 & 48 & 30 \\
\hline GBP & 0.998 & 0.998 & 0.997 \\
\hline & 0.012 & 0.011 & -0.017 \\
\hline
\end{tabular}

\subsection{Malaysian ringgit (myr)}

\begin{tabular}{|c|c|c|c|c|}
\hline & $(1)$ & $(2)$ & (3) & (4) \\
\hline & myr 92-95 & $96-99$ & $00-03$ & $04-07$ \\
\hline \multirow[t]{2}{*}{ JPY } & -0.072 & -0.131 & -0.000 & -0.038 \\
\hline & $(0.192)$ & $(0.149)$ & $(0.000)$ & $(0.057)$ \\
\hline \multirow[t]{2}{*}{ USD } & -0.001 & 0.191 & $1.000 * * *$ & $0.619 * * *$ \\
\hline & $(2.019)$ & $(0.268)$ & $(0.000)$ & $(0.097)$ \\
\hline \multirow[t]{2}{*}{ KRW } & -0.163 & -0.046 & 0.000 & -0.111 \\
\hline & $(0.447)$ & $(0.063)$ & $(0.000)$ & $(0.070)$ \\
\hline \multirow[t]{2}{*}{ SGD } & $0.930^{*}$ & $1.125^{*}$ & -0.000 & $0.441 * * *$ \\
\hline & $(0.493)$ & $(0.583)$ & $(0.000)$ & $(0.148)$ \\
\hline \multirow[t]{2}{*}{ AUD } & -0.075 & -0.121 & 0.000 & 0.023 \\
\hline & $(0.104)$ & $(0.174)$ & $(0.000)$ & $(0.046)$ \\
\hline \multirow[t]{2}{*}{ THB } & 0.487 & 0.065 & 0.000 & 0.051 \\
\hline & $(2.145)$ & $(0.244)$ & $(0.000)$ & $(0.067)$ \\
\hline \multirow[t]{2}{*}{ German mark } & -0.072 & -0.061 & & \\
\hline & $(0.174)$ & $(0.205)$ & & \\
\hline \multirow[t]{2}{*}{$\Delta\left[\log \operatorname{Res}^{+}+\log \mathrm{Ex}\right]$} & 0.009 & $0.350 * * *$ & -0.000 & $0.081^{* *}$ \\
\hline & $(0.038)$ & $(0.098)$ & $(0.000)$ & $(0.035)$ \\
\hline \multirow[t]{2}{*}{ Euro } & & & -0.000 & 0.008 \\
\hline & & & $(0.000)$ & $(0.088)$ \\
\hline \multirow[t]{2}{*}{ Constant } & -0.001 & -0.005 & 0.000 & 0.000 \\
\hline & $(0.003)$ & $(0.005)$ & $(0.000)$ & $(0.001)$ \\
\hline Observations & 48 & 36 & 48 & 40 \\
\hline R-squared & 0.831 & 0.868 & 1.000 & 0.942 \\
\hline GBP & -0.034 & -0.021 & 0.000 & 0.005 \\
\hline
\end{tabular}

\subsection{Botswana pula (bwp)}

\begin{tabular}{|l|l|l|l|l|l|l|l|}
\hline & $(1)$ & $(2)$ & $(3)$ & $(4)$ & $(5)$ & $(6)$ & $(7)$ \\
\hline & bwp 80-83 & $84-87$ & $88-91$ & $92-95$ & $96-99$ & $00-03$ & $04-07$ \\
\hline JPY & $0.365^{* *}$ & $0.477^{* *}$ & 0.062 & 0.028 & $0.169^{* * *}$ & $0.211^{* * *}$ & 0.190 \\
\hline & $(0.146)$ & $(0.211)$ & $(0.081)$ & $(0.038)$ & $(0.059)$ & $(0.078)$ & $(0.136)$ \\
\hline USD & $0.654^{* * *}$ & 0.030 & $0.470^{* * *}$ & $0.569^{* * *}$ & -0.008 & $0.296^{* *}$ & 0.063 \\
\hline & $(0.076)$ & $(0.281)$ & $(0.063)$ & $(0.041)$ & $(0.206)$ & $(0.110)$ & $(0.149)$ \\
\hline
\end{tabular}




\begin{tabular}{|l|l|l|l|l|l|l|l|}
\hline French franc & 0.022 & $0.613^{*}$ & $0.417^{* * *}$ & & & & \\
\hline & $(0.130)$ & $(0.359)$ & $(0.109)$ & & & & \\
\hline$\Delta[\operatorname{logRes}+\operatorname{logEx}]$ & -0.010 & 0.016 & $0.440^{* * *}$ & $0.236^{* * *}$ & $0.566^{* * *}$ & $0.636^{* * *}$ & $0.725^{* * *}$ \\
\hline & $(0.064)$ & $(0.031)$ & $(0.064)$ & $(0.053)$ & $(0.078)$ & $(0.053)$ & $(0.096)$ \\
\hline German mark & & & & $0.314^{* * *}$ & $0.433^{* * *}$ & & \\
\hline & & & & $(0.061)$ & $(0.157)$ & & \\
\hline Euro & & & & & & $0.312^{* * *}$ & $0.581^{* * *}$ \\
\hline & & & & & & $(0.105)$ & $(0.194)$ \\
\hline Constant & $-0.009^{*}$ & $-0.018^{* *}$ & $-0.009^{* * *}$ & $-0.006^{* * *}$ & $-0.009^{* * *}$ & 0.003 & $-0.011^{* * *}$ \\
\hline & $(0.005)$ & $(0.007)$ & $(0.002)$ & $(0.001)$ & $(0.003)$ & $(0.003)$ & $(0.003)$ \\
\hline Observations & 46 & 48 & 48 & 48 & 36 & 48 & 37 \\
\hline R-squared & 0.652 & 0.266 & 0.827 & 0.905 & 0.801 & 0.783 & 0.811 \\
\hline GBP & -0.041 & -0.120 & 0.051 & 0.089 & 0.406 & 0.181 & 0.166 \\
\hline
\end{tabular}

\subsection{Chile (clp)}

\begin{tabular}{|c|c|c|c|c|c|c|c|}
\hline & (1) & $(2)$ & (3) & (4) & $(5)$ & $(6)$ & (7) \\
\hline & $\operatorname{clp} 80-83$ & $84-87$ & $88-91$ & $92-95$ & $96-99$ & $00-03$ & 04-07 \\
\hline \multirow[t]{2}{*}{ JPY } & -0.077 & $0.638 * *$ & 0.046 & $0.201 * * *$ & $0.108 * * *$ & 0.172 & -0.031 \\
\hline & $(0.084)$ & $(0.255)$ & $(0.134)$ & $(0.057)$ & $(0.035)$ & $(0.108)$ & $(0.143)$ \\
\hline \multirow[t]{2}{*}{ USD } & $0.642 * * *$ & $0.609 * *$ & $0.957 * * *$ & $0.644 * * *$ & $0.884 * * *$ & $0.376^{* *}$ & $0.755^{* * *}$ \\
\hline & $(0.232)$ & $(0.269)$ & $(0.112)$ & $(0.072)$ & $(0.079)$ & $(0.181)$ & $(0.152)$ \\
\hline \multirow[t]{2}{*}{ French franc } & 0.421 & -0.101 & $-0.233 * *$ & & & & \\
\hline & $(0.282)$ & $(0.442)$ & $(0.112)$ & & & & \\
\hline \multirow[t]{2}{*}{$\Delta[\log \operatorname{Res}+\log \mathrm{Ex}]$} & $0.192 * *$ & $0.513 * *$ & 0.036 & $0.390 * * *$ & $0.228 * * *$ & $0.675^{* * *}$ & $0.217 * * *$ \\
\hline & $(0.081)$ & $(0.222)$ & $(0.052)$ & $(0.062)$ & $(0.037)$ & $(0.100)$ & $(0.050)$ \\
\hline \multirow[t]{2}{*}{ German mark } & & & & 0.029 & $0.109^{*}$ & & \\
\hline & & & & $(0.091)$ & $(0.062)$ & & \\
\hline \multirow[t]{2}{*}{ Euro } & & & & & & $0.238 * *$ & $0.584 * *$ \\
\hline & & & & & & $(0.100)$ & $(0.259)$ \\
\hline \multirow[t]{2}{*}{ Constant } & $-0.006^{*}$ & $-0.015^{* *}$ & $-0.010 * * *$ & $-0.006 * * *$ & $-0.004 * * *$ & -0.001 & 0.002 \\
\hline & $(0.003)$ & $(0.007)$ & $(0.002)$ & $(0.002)$ & $(0.001)$ & $(0.003)$ & $(0.003)$ \\
\hline Observations & 46 & 48 & 48 & 48 & 36 & 48 & 41 \\
\hline R-squared & 0.681 & 0.768 & 0.886 & 0.907 & 0.911 & 0.769 & 0.692 \\
\hline GBP & 0.014 & -0.146 & 0.230 & 0.127 & -0.101 & 0.214 & -0.307 \\
\hline
\end{tabular}

\subsection{Danish krone (dkk)}

\begin{tabular}{|c|c|c|c|c|c|c|c|}
\hline & (1) & $(2)$ & (3) & (4) & $(5)$ & (6) & $(7)$ \\
\hline & $80-83$ & $84-87$ & $88-91$ & $92-95$ & $96-99$ & $00-03$ & 04-07 \\
\hline \multirow[t]{2}{*}{ JPY } & 0.063 & 0.107 & -0.015 & 0.004 & 0.004 & -0.004 & 0.008 \\
\hline & $(0.060)$ & $(0.083)$ & $(0.053)$ & $(0.038)$ & $(0.008)$ & $(0.021)$ & $(0.017)$ \\
\hline \multirow[t]{2}{*}{ USD } & 0.091 & -0.052 & $0.053^{*}$ & 0.041 & 0.007 & 0.000 & -0.020 \\
\hline & $(0.091)$ & $(0.047)$ & $(0.030)$ & $(0.037)$ & $(0.014)$ & $(0.018)$ & $(0.017)$ \\
\hline \multirow[t]{2}{*}{ French franc } & $0.833 * * *$ & $0.851 * * *$ & $0.985 * * *$ & & & & \\
\hline & $(0.118)$ & $(0.102)$ & $(0.047)$ & & & & \\
\hline \multirow[t]{2}{*}{$\Delta[\log \operatorname{Res}+\log E x]$} & -0.003 & 0.011 & 0.016 & 0.022 & 0.005 & 0.001 & -0.001 \\
\hline & $(0.020)$ & $(0.010)$ & $(0.013)$ & $(0.021)$ & $(0.005)$ & $(0.008)$ & $(0.007)$ \\
\hline \multirow[t]{2}{*}{ German mark } & & & & $0.869 * * *$ & $0.964 * * *$ & & \\
\hline & & & & $(0.097)$ & $(0.019)$ & & \\
\hline \multirow[t]{2}{*}{ Euro } & & & & & & $1.000^{* * *}$ & $0.939 * * *$ \\
\hline & & & & & & $(0.023)$ & $(0.055)$ \\
\hline \multirow[t]{2}{*}{ Constant } & 0.000 & 0.000 & 0.000 & 0.000 & 0.000 & -0.000 & 0.000 \\
\hline & $(0.002)$ & $(0.001)$ & $(0.001)$ & $(0.001)$ & $(0.000)$ & $(0.000)$ & $(0.000)$ \\
\hline Observations & 46 & 48 & 48 & 48 & 36 & 48 & 41 \\
\hline R-squared & 0.852 & 0.856 & 0.918 & 0.838 & 0.991 & 0.981 & 0.965 \\
\hline GBP & 0.013 & 0.094 & -0.022 & 0.086 & 0.025 & 0.004 & 0.073 \\
\hline
\end{tabular}


2.7 Fiji dollar

\begin{tabular}{|c|c|c|c|c|c|c|c|}
\hline & (1) & $(2)$ & (3) & (4) & (5) & $(6)$ & (7) \\
\hline & fiji $80-83$ & $84-87$ & $88-91$ & $92-95$ & 96-99 & $00-03$ & 04-07 \\
\hline \multirow[t]{2}{*}{ JPY } & $0.154 * * *$ & 0.057 & -0.086 & -0.184 & 0.085 & 0.086 & 0.008 \\
\hline & $(0.030)$ & $(0.157)$ & $(0.090)$ & $(0.141)$ & $(0.106)$ & $(0.055)$ & $(0.053)$ \\
\hline \multirow[t]{2}{*}{ USD } & $0.379 * * *$ & $1.435 * *$ & $-1.517 * * *$ & $-2.401 * *$ & $0.482 * *$ & $0.229 * * *$ & 0.317 \\
\hline & $(0.108)$ & $(0.616)$ & $(0.549)$ & $(1.122)$ & $(0.197)$ & $(0.063)$ & $(0.205)$ \\
\hline \multirow[t]{2}{*}{ KRW } & $-0.158^{*}$ & -0.981 & 0.050 & $0.785 * *$ & -0.030 & 0.044 & 0.137 \\
\hline & $(0.083)$ & $(0.587)$ & $(0.093)$ & $(0.292)$ & $(0.043)$ & $(0.045)$ & $(0.096)$ \\
\hline \multirow[t]{2}{*}{ SGD } & -0.040 & -0.329 & 0.091 & 0.121 & -0.064 & 0.064 & -0.151 \\
\hline & $(0.092)$ & $(0.273)$ & $(0.122)$ & $(0.204)$ & $(0.276)$ & $(0.090)$ & $(0.208)$ \\
\hline \multirow[t]{2}{*}{ AUD } & $0.266^{* * *}$ & $0.344^{* *}$ & $0.241 * * *$ & $0.214^{* * *}$ & -0.195 & $0.436^{* * *}$ & $0.436^{* * *}$ \\
\hline & $(0.084)$ & $(0.159)$ & $(0.045)$ & $(0.056)$ & $(0.342)$ & $(0.054)$ & $(0.076)$ \\
\hline \multirow[t]{2}{*}{ MYR } & $0.177^{*}$ & 0.276 & -0.074 & -0.013 & 0.330 & 0.000 & 0.061 \\
\hline & $(0.100)$ & $(0.352)$ & $(0.180)$ & $(0.074)$ & $(0.237)$ & $(0.000)$ & $(0.261)$ \\
\hline \multirow[t]{2}{*}{ THB } & 0.025 & -0.046 & $2.344 * * *$ & $2.528 * *$ & -0.037 & -0.075 & -0.086 \\
\hline & $(0.023)$ & $(0.050)$ & $(0.681)$ & $(1.171)$ & $(0.099)$ & $(0.069)$ & $(0.080)$ \\
\hline \multirow[t]{2}{*}{ French franc } & 0.007 & 0.096 & -0.092 & & & & \\
\hline & $(0.030)$ & $(0.183)$ & $(0.062)$ & & & & \\
\hline \multirow[t]{2}{*}{$\Delta\left[\log \operatorname{Res}^{+}+\log \mathrm{Ex}\right]$} & 0.006 & $0.201 * * *$ & -0.011 & -0.025 & $0.373^{*}$ & 0.031 & 0.014 \\
\hline & $(0.006)$ & $(0.059)$ & $(0.016)$ & $(0.017)$ & $(0.212)$ & $(0.021)$ & $(0.020)$ \\
\hline \multirow[t]{2}{*}{ German mark } & & & & $-0.207 * *$ & 0.186 & & \\
\hline & & & & $(0.087)$ & $(0.183)$ & & \\
\hline \multirow[t]{2}{*}{ Euro } & & & & & & $0.187 * * *$ & 0.106 \\
\hline & & & & & & $(0.042)$ & $(0.103)$ \\
\hline \multirow[t]{2}{*}{ Constant } & $-0.003^{*}$ & -0.003 & -0.001 & 0.002 & -0.006 & 0.001 & -0.001 \\
\hline & $(0.001)$ & $(0.004)$ & $(0.001)$ & $(0.002)$ & $(0.005)$ & $(0.001)$ & $(0.001)$ \\
\hline Observations & 46 & 48 & 48 & 48 & 36 & 48 & 34 \\
\hline R-squared & 0.954 & 0.730 & 0.963 & 0.966 & 0.562 & 0.946 & 0.885 \\
\hline GBP & 0.191 & 0.147 & 0.043 & 0.158 & 0.243 & 0.029 & 0.171 \\
\hline
\end{tabular}

\subsection{Latvian lat (lvl)}

\begin{tabular}{|l|l|l|l|l|}
\hline & $(1)$ & $(2)$ & $(3)$ & $(4)$ \\
\hline & $1 \mathrm{l} 192-95$ & $96-99$ & $00-03$ & $04-07$ \\
\hline JPY & $0.319^{* * *}$ & $0.168^{* * *}$ & $0.110^{* * *}$ & -0.008 \\
\hline & $(0.079)$ & $(0.012)$ & $(0.026)$ & $(0.055)$ \\
\hline USD & $0.427^{* *}$ & $0.434^{* * *}$ & $0.338^{* * *}$ & -0.096 \\
\hline & $(0.169)$ & $(0.025)$ & $(0.088)$ & $(0.124)$ \\
\hline RUB & 0.014 & -0.006 & 0.118 & $0.455^{* * *}$ \\
\hline & $(0.039)$ & $(0.006)$ & $(0.085)$ & $(0.154)$ \\
\hline German mark & 0.260 & $0.270^{* * *}$ & & \\
\hline & $(0.148)$ & $(0.032)$ & & 0.027 \\
\hline$\Delta[\operatorname{logRes}+\operatorname{logEx}]$ & $0.109 * *$ & $0.024^{* *}$ & 0.009 & $(0.021)$ \\
\hline & $(0.045)$ & $(0.010)$ & $(0.013)$ & $0.496^{* * *}$ \\
\hline Euro & & & $0.197 * * *$ & $(0.092)$ \\
\hline & & & $(0.024)$ & -0.003 \\
\hline Constant & 0.004 & -0.001 & 0.000 & $(0.002)$ \\
\hline & $(0.002)$ & $(0.001)$ & $(0.001)$ & 42 \\
\hline Observations & 16 & 36 & 48 & 0.617 \\
\hline R-squared & 0.824 & 0.958 & 0.925 & 0.154 \\
\hline GBP & -0.019 & 0.133 & 0.237 & \\
\hline
\end{tabular}




\subsection{Maltese lira (mtl)}

\begin{tabular}{|c|c|c|c|c|c|c|c|}
\hline & (1) & (2) & (3) & (4) & (5) & (6) & (7) \\
\hline & $\mathrm{mtl} 80-83$ & $84-87$ & $88-91$ & $92-95$ & $96-99$ & $00-03$ & 04-07 \\
\hline \multirow[t]{2}{*}{ JPY } & $0.054 *$ & $0.163 * * *$ & 0.011 & 0.085 & 0.178 & $0.041 * *$ & -0.002 \\
\hline & $(0.030)$ & $(0.049)$ & $(0.033)$ & $(0.086)$ & $(0.143)$ & $(0.020)$ & $(0.032)$ \\
\hline \multirow[t]{2}{*}{ USD } & $0.405^{* * *}$ & $0.258 * * *$ & $0.288^{* * *}$ & $0.242 * * *$ & $0.400^{* *}$ & $0.212 * * *$ & $0.055^{*}$ \\
\hline & $(0.053)$ & $(0.036)$ & $(0.027)$ & $(0.077)$ & $(0.187)$ & $(0.034)$ & $(0.031)$ \\
\hline \multirow[t]{2}{*}{ French franc } & $0.280 * * *$ & $0.407 * * *$ & $0.381 * * *$ & & & & \\
\hline & $(0.053)$ & $(0.064)$ & $(0.041)$ & & & & \\
\hline \multirow[t]{2}{*}{$\Delta\left[\log \operatorname{Res}^{+}+\log \mathrm{Ex}\right]$} & $0.061 * *$ & 0.083 & 0.034 & 0.212 & $0.540 * * *$ & $0.073 * * *$ & 0.029 \\
\hline & $(0.028)$ & $(0.089)$ & $(0.039)$ & $(0.162)$ & $(0.126)$ & $(0.026)$ & $(0.021)$ \\
\hline \multirow[t]{2}{*}{ German mark } & & & & $0.419 * * *$ & 0.168 & & \\
\hline & & & & $(0.088)$ & $(0.230)$ & & \\
\hline \multirow[t]{2}{*}{ Euro } & & & & & & $0.502 * * *$ & $0.859 * * *$ \\
\hline & & & & & & $(0.024)$ & $(0.054)$ \\
\hline \multirow[t]{2}{*}{ Constant } & 0.001 & 0.001 & 0.000 & -0.003 & -0.002 & 0.000 & -0.000 \\
\hline & $(0.001)$ & $(0.001)$ & $(0.001)$ & $(0.002)$ & $(0.004)$ & $(0.001)$ & $(0.001)$ \\
\hline Observations & 46 & 48 & 48 & 48 & 36 & 45 & 41 \\
\hline R-squared & 0.875 & 0.918 & 0.933 & 0.592 & 0.724 & 0.934 & 0.894 \\
\hline GBP & 0.261 & 0.171 & 0.321 & 0.253 & 0.253 & 0.245 & 0.089 \\
\hline
\end{tabular}

\subsection{Norwegian kroner (nok)}

\begin{tabular}{|c|c|c|c|c|c|c|c|}
\hline & $(1)$ & $(2)$ & (3) & $(4)$ & $(5)$ & $(6)$ & $(7)$ \\
\hline & nok $80-83$ & $84-87$ & $88-91$ & $92-95$ & $96-99$ & $00-03$ & 04-07 \\
\hline \multirow[t]{2}{*}{ JPY } & 0.117 & $0.119^{*}$ & 0.016 & -0.037 & -0.074 & 0.081 & 0.123 \\
\hline & $(0.073)$ & $(0.068)$ & $(0.058)$ & $(0.048)$ & $(0.051)$ & $(0.079)$ & $(0.168)$ \\
\hline \multirow[t]{2}{*}{ USD } & $0.332 * * *$ & 0.067 & $0.177 * * *$ & $0.089 * *$ & $0.260 * *$ & 0.017 & -0.089 \\
\hline & $(0.089)$ & $(0.067)$ & $(0.033)$ & $(0.044)$ & $(0.114)$ & $(0.110)$ & $(0.144)$ \\
\hline \multirow[t]{2}{*}{ French franc } & $0.391 * * *$ & $0.699 * * *$ & $0.578 * * *$ & & & & \\
\hline & $(0.092)$ & $(0.116)$ & $(0.066)$ & & & & \\
\hline \multirow[t]{2}{*}{$\Delta\left[\log \operatorname{Res}^{+}+\log \mathrm{Ex}\right]$} & 0.017 & $0.106^{*}$ & $0.069 * *$ & 0.050 & $0.076^{* *}$ & 0.029 & $0.093 * *$ \\
\hline & $(0.026)$ & $(0.054)$ & $(0.029)$ & $(0.031)$ & $(0.035)$ & $(0.057)$ & $(0.044)$ \\
\hline \multirow[t]{2}{*}{ German mark } & & & & $0.776^{* * *}$ & $0.873 * * *$ & & \\
\hline & & & & $(0.066)$ & $(0.100)$ & & \\
\hline \multirow[t]{2}{*}{ Euro } & & & & & & $0.803 * * *$ & $1.135^{* * *}$ \\
\hline & & & & & & $(0.113)$ & $(0.220)$ \\
\hline \multirow[t]{2}{*}{ Constant } & -0.003 & $-0.005 * *$ & 0.001 & -0.002 & -0.001 & -0.000 & 0.001 \\
\hline & $(0.002)$ & $(0.002)$ & $(0.001)$ & $(0.002)$ & $(0.002)$ & $(0.003)$ & $(0.003)$ \\
\hline Observations & 46 & 48 & 48 & 48 & 36 & 48 & 42 \\
\hline R-squared & 0.728 & 0.768 & 0.781 & 0.798 & 0.793 & 0.624 & 0.546 \\
\hline GBP & 0.160 & 0.115 & 0.229 & 0.171 & -0.060 & 0.100 & -0.169 \\
\hline
\end{tabular}


2.12 Papua New Guinea kina (png)

\begin{tabular}{|l|l|l|l|l|}
\hline & $(1)$ & $(2)$ & $(3)$ & $(4)$ \\
\hline & png 92-95 & $96-99$ & $00-03$ & $04-07$ \\
\hline JPY & 0.209 & $0.545^{* *}$ & 0.155 & 0.004 \\
\hline & $(0.285)$ & $(0.200)$ & $(0.319)$ & $(0.048)$ \\
\hline USD & 1.987 & $1.148^{* * *}$ & $14,177.172$ & $1.068^{* * *}$ \\
\hline KRW & $(2.344)$ & $(0.390)$ & $(8,742.646)$ & $(0.093)$ \\
\hline & $-1.244^{* *}$ & -0.038 & 0.196 & 0.009 \\
\hline SGD & $(0.515)$ & $(0.092)$ & $(0.282)$ & $(0.060)$ \\
\hline & -0.427 & -0.811 & -0.147 & 0.091 \\
\hline AUD & $(0.666)$ & $(0.647)$ & $(0.606)$ & $(0.143)$ \\
\hline & $0.288^{* *}$ & 0.078 & 0.083 & 0.013 \\
\hline MYR & $(0.136)$ & $(0.307)$ & $(0.219)$ & $(0.053)$ \\
\hline & -0.008 & 0.365 & $-14,176.404$ & $-0.191 *$ \\
\hline THB & $(0.206)$ & $(0.233)$ & $(8,742.737)$ & $(0.095)$ \\
\hline & 0.189 & 0.000 & -0.092 & -0.004 \\
\hline German mark & $(2.626)$ & $(0.099)$ & $(0.392)$ & $(0.062)$ \\
\hline$*$ & 0.140 & -0.228 & & \\
\hline$\Delta[\operatorname{logRes}+\operatorname{logEx}]$ & $(0.254)$ & $(0.293)$ & & \\
\hline & 0.008 & $0.105^{* *}$ & $0.308^{* * *}$ & 0.010 \\
\hline Euro & $(0.012)$ & $(0.041)$ & $(0.050)$ & $(0.010)$ \\
\hline & & & 0.271 & -0.017 \\
\hline Constant & $-0.008^{* *}$ & -0.009 & $(0.309)$ & $(0.070)$ \\
\hline & $(0.004)$ & $(0.006)$ & -0.009 & $0.002^{* *}$ \\
\hline Observations & 48 & 36 & $(0.006)$ & $0.001)$ \\
\hline R-squared & 0.725 & 0.545 & 48 & 41 \\
\hline GBP & -0.134 & -0.059 & 0.671 & 0.965 \\
\hline & & & -0.234 & 0.026 \\
\hline & & & \\
\hline & & & \\
\hline
\end{tabular}

\subsection{Russia (rub)}

\begin{tabular}{|c|c|c|c|c|}
\hline & (1) & (2) & (3) & (4) \\
\hline & rub $92-95$ & $96-99$ & $00-03$ & 04-07 \\
\hline \multirow[t]{2}{*}{ JPY } & -0.491 & -0.272 & 0.105 & $0.101^{* *}$ \\
\hline & $(0.437)$ & $(0.291)$ & $(0.070)$ & $(0.043)$ \\
\hline \multirow[t]{2}{*}{ USD } & 0.873 & $2.746^{* * *}$ & $0.787 * * *$ & 0.591 *** \\
\hline & (1.077) & $(1.142)$ & $(0.070)$ & $(0.049)$ \\
\hline \multirow[t]{2}{*}{ German mark } & -0.802 & -0.798 & & \\
\hline & $(1.410)$ & $(0.783)$ & & \\
\hline \multirow{2}{*}{$\Delta[\log R e s+\log E x]$} & 0.111 & $0.379^{* *}$ & $0.101 * * *$ & $0.088^{*}$ \\
\hline & $(0.141)$ & $(0.145)$ & $(0.019)$ & $\begin{array}{l}(0.048) \\
\end{array}$ \\
\hline \multirow[t]{2}{*}{ Euro } & & & 0.064 & 0.150 \\
\hline & & & $\begin{array}{l}(0.070) \\
\end{array}$ & $\begin{array}{l}(0.151) \\
\end{array}$ \\
\hline \multirow[t]{2}{*}{ Constant } & -0.024 & $-0.024 * *$ & $-0.006^{* * *}$ & -0.001 \\
\hline & $(0.025)$ & $(0.012)$ & $(0.002)$ & $(0.002)$ \\
\hline Observations & 11 & 36 & 48 & 42 \\
\hline R-squared & 0.514 & 0.602 & 0.863 & 0.832 \\
\hline GBP & 1.420 & -0.675 & 0.045 & 0.158 \\
\hline
\end{tabular}




\subsection{Seychelles rupee (scr)}

\begin{tabular}{|c|c|c|c|c|c|c|c|}
\hline & $(1)$ & $(2)$ & (3) & $(4)$ & $(5)$ & $(6)$ & $(7)$ \\
\hline & scr $80-83$ & $84-87$ & $88-91$ & $92-95$ & $96-99$ & $00-03$ & 04-07 \\
\hline \multirow[t]{2}{*}{ JPY } & -0.068 & $0.230 * * *$ & $0.178 * * *$ & $0.201 * * *$ & 0.030 & $0.321 * * *$ & 0.073 \\
\hline & $(0.154)$ & $(0.033)$ & $(0.020)$ & $(0.016)$ & $(0.049)$ & $(0.115)$ & $(0.086)$ \\
\hline \multirow[t]{2}{*}{ USD } & $0.391 * * *$ & $0.417 * * *$ & $0.370 * * *$ & $0.396^{* * *}$ & $0.586^{* * *}$ & $0.367 * * *$ & $0.934 * * *$ \\
\hline & $(0.099)$ & $(0.024)$ & $(0.021)$ & $(0.016)$ & $(0.113)$ & $(0.125)$ & $(0.080)$ \\
\hline \multirow[t]{2}{*}{ French franc } & $0.430 * * *$ & $0.250 * * *$ & $0.312 * * *$ & & & & \\
\hline & $(0.135)$ & $(0.038)$ & $(0.028)$ & & & & \\
\hline \multirow[t]{2}{*}{$\Delta[\log R e s+\log E x]$} & 0.015 & -0.002 & 0.002 & -0.004 & 0.013 & 0.011 & 0.007 \\
\hline & $(0.018)$ & $(0.003)$ & $(0.002)$ & $(0.002)$ & $(0.015)$ & $(0.017)$ & $(0.009)$ \\
\hline \multirow[t]{2}{*}{ German mark } & & & & $0.277 * * *$ & 0.085 & & \\
\hline & & & & $(0.018)$ & $(0.140)$ & & \\
\hline \multirow[t]{2}{*}{ Euro } & & & & & & -0.030 & 0.149 \\
\hline & & & & & & $(0.126)$ & $(0.096)$ \\
\hline \multirow[t]{2}{*}{ Constant } & 0.007 & 0.000 & -0.000 & 0.000 & -0.003 & -0.001 & $-0.003 * *$ \\
\hline & $(0.006)$ & $(0.001)$ & $(0.000)$ & $(0.000)$ & $(0.002)$ & $(0.003)$ & $(0.001)$ \\
\hline Observations & 46 & 48 & 48 & 48 & 36 & 48 & 42 \\
\hline R-squared & 0.530 & 0.972 & 0.982 & 0.992 & 0.565 & 0.391 & 0.833 \\
\hline GBP & 0.246 & 0.103 & 0.140 & 0.125 & 0.299 & 0.343 & -0.156 \\
\hline
\end{tabular}

\subsection{Thailand (thb)}

\begin{tabular}{|c|c|c|c|c|c|c|c|}
\hline & (1) & (2) & (3) & (4) & (5) & (6) & (7) \\
\hline & thb $80-83$ & $84-87$ & $88-91$ & $92-95$ & 96-99 & 00-03 & 04-07 \\
\hline \multirow[t]{2}{*}{ JPY } & 0.146 & $0.093 * *$ & $0.115^{* * *}$ & $0.106 * * *$ & -0.005 & 0.121 & 0.034 \\
\hline & $(0.134)$ & $(0.042)$ & $(0.009)$ & $(0.008)$ & $(0.206)$ & $(0.107)$ & $(0.072)$ \\
\hline \multirow[t]{2}{*}{ USD } & $1.033 * * *$ & 0.319 & $0.754 * * *$ & $0.883 * * *$ & -0.510 & $-1,767.883$ & 0.255 \\
\hline & $(0.130)$ & $(0.446)$ & $(0.040)$ & $(0.026)$ & $(0.365)$ & $(2,073.342)$ & $(0.225)$ \\
\hline \multirow[t]{2}{*}{ KRW } & -0.186 & 0.238 & 0.026 & $-0.099 * * *$ & 0.116 & 0.022 & 0.155 \\
\hline & $(0.236)$ & $(0.457)$ & $(0.018)$ & $(0.029)$ & $(0.071)$ & $(0.099)$ & $(0.111)$ \\
\hline \multirow[t]{2}{*}{ SGD } & -0.291 & 0.304 & $0.036^{*}$ & 0.016 & 0.598 & 0.068 & 0.188 \\
\hline & $(0.307)$ & $(0.190)$ & $(0.020)$ & $(0.032)$ & $(0.621)$ & $(0.217)$ & $(0.207)$ \\
\hline \multirow[t]{2}{*}{ AUD } & -0.090 & -0.006 & $0.014^{* * * *}$ & $0.016^{*}$ & -0.264 & $0.107^{*}$ & -0.014 \\
\hline & $(0.086)$ & $(0.061)$ & $(0.004)$ & $(0.009)$ & $(0.206)$ & $(0.060)$ & $(0.074)$ \\
\hline \multirow[t]{2}{*}{ MYR } & 0.436 & 0.018 & -0.005 & -0.003 & $0.575 * *$ & $1,768.353$ & -0.001 \\
\hline & $(0.451)$ & $(0.196)$ & $(0.032)$ & $(0.009)$ & $(0.259)$ & $(2,073.400)$ & $(0.250)$ \\
\hline \multirow[t]{2}{*}{ French franc } & -0.061 & -0.026 & $0.049 * * *$ & & & & \\
\hline & $(0.080)$ & $(0.074)$ & $(0.010)$ & & & & \\
\hline \multirow[t]{2}{*}{$\Delta[\log \operatorname{Res}+\log \mathrm{Ex}]$} & 0.004 & -0.093 & -0.005 & 0.012 & 0.239 & $0.368 * * *$ & $0.458 * * *$ \\
\hline & $(0.014)$ & $(0.089)$ & $(0.007)$ & $(0.008)$ & $(0.185)$ & $(0.114)$ & $(0.076)$ \\
\hline \multirow[t]{2}{*}{ German mark } & & & & $0.071 * * *$ & 0.361 & & \\
\hline & & & & $(0.010)$ & $(0.345)$ & & \\
\hline \multirow[t]{2}{*}{ Euro } & & & & & & $0.255 * *$ & 0.158 \\
\hline & & & & & & $(0.118)$ & $(0.100)$ \\
\hline \multirow[t]{2}{*}{ Constant } & -0.005 & -0.003 & -0.000 & $-0.001 * * *$ & 0.003 & -0.002 & $-0.006^{* * *}$ \\
\hline & $(0.004)$ & $(0.004)$ & $(0.000)$ & $(0.000)$ & $(0.006)$ & $(0.002)$ & $(0.001)$ \\
\hline Observations & 46 & 48 & 48 & 48 & 36 & 48 & 42 \\
\hline R-squared & 0.840 & 0.650 & 0.999 & 0.999 & 0.839 & 0.828 & 0.861 \\
\hline GBP & 0.012 & 0.059 & 0.012 & 0.010 & 0.128 & -0.043 & 0.225 \\
\hline
\end{tabular}




\subsection{Vanuatu vatu (vuv)}

\begin{tabular}{|l|l|l|l|l|l|l|l|}
\hline & $(1)$ & $(2)$ & $(3)$ & $(4)$ & $(5)$ & $(6)$ & $(7)$ \\
\hline & vuv 80-83 & $84-87$ & $88-91$ & $92-95$ & $96-99$ & $00-03$ & $04-07$ \\
\hline JPY & 0.074 & $0.583^{*}$ & 0.242 & 0.101 & $0.097^{* *}$ & $0.240^{* * *}$ & 0.035 \\
\hline & $(0.054)$ & $(0.312)$ & $(0.164)$ & $(0.064)$ & $(0.044)$ & $(0.059)$ & $(0.075)$ \\
\hline USD & $0.407^{* * *}$ & $0.347^{*}$ & $0.504^{* * *}$ & $0.744^{* * *}$ & $0.681^{* * *}$ & $0.435^{* * *}$ & $0.463^{* * *}$ \\
\hline & $(0.104)$ & $(0.179)$ & $(0.131)$ & $(0.080)$ & $(0.104)$ & $(0.073)$ & $(0.079)$ \\
\hline French franc & $0.320^{* * *}$ & -0.180 & $0.557^{* *}$ & & & & \\
\hline & $(0.104)$ & $(0.377)$ & $(0.237)$ & & & & \\
\hline$\Delta[\operatorname{logRes}+\operatorname{logEx}]$ & 0.001 & 0.010 & $0.152^{* * *}$ & $0.100^{* *}$ & -0.009 & $0.104^{* * *}$ & $0.153^{* * *}$ \\
\hline & $(0.003)$ & $(0.053)$ & $(0.056)$ & $(0.042)$ & $(0.042)$ & $(0.037)$ & $(0.049)$ \\
\hline German mark & & & & -0.004 & 0.039 & & $(0.084)$ \\
\hline & & & & $(0.087)$ & & $0.293^{* * *}$ & -0.009 \\
\hline Euro & & & & & & $(0.081)$ & $(0.121)$ \\
\hline & & & & & & 0.002 & $-0.003^{* *}$ \\
\hline Constant & 0.001 & -0.007 & -0.002 & -0.001 & $-0.004 *$ & $(0.002)$ & $(0.002)$ \\
\hline & $(0.001)$ & $(0.005)$ & $(0.003)$ & $(0.002)$ & $(0.002)$ & $(0.002)$ \\
\hline Observations & 34 & 48 & 48 & 48 & 36 & 44 & 37 \\
\hline R-squared & 0.834 & 0.461 & 0.683 & 0.872 & 0.675 & 0.704 & 0.709 \\
\hline GBP & 0.199 & 0.250 & -0.303 & 0.159 & 0.184 & 0.033 & 0.511 \\
\hline
\end{tabular}

\subsection{Western Samoa tala (wst)}

\begin{tabular}{|c|c|c|c|c|c|c|c|}
\hline & (1) & (2) & (3) & (4) & (5) & (6) & (7) \\
\hline & wst $80-83$ & $84-87$ & $88-91$ & $92-95$ & $96-99$ & $00-03$ & 04-07 \\
\hline \multirow[t]{2}{*}{ JPY } & $0.254 * * *$ & 0.152 & $0.350 * * *$ & $0.153 * * *$ & $0.211 * * *$ & $0.176^{* * *}$ & 0.037 \\
\hline & $(0.051)$ & $(0.132)$ & $(0.075)$ & $(0.042)$ & $(0.048)$ & $(0.062)$ & $(0.074)$ \\
\hline \multirow[t]{2}{*}{ USD } & $0.597 * * *$ & $0.400 * *$ & $0.538 * * *$ & $0.759 * * *$ & $0.710 * * *$ & $0.574 * * *$ & $0.542 * * *$ \\
\hline & $(0.104)$ & $(0.193)$ & $(0.136)$ & $(0.047)$ & $(0.154)$ & $(0.079)$ & $(0.070)$ \\
\hline \multirow[t]{2}{*}{ French franc } & 0.075 & 0.084 & 0.004 & & & & \\
\hline & $(0.129)$ & $(0.228)$ & $(0.209)$ & & & & \\
\hline \multirow[t]{2}{*}{$\Delta\left[\log \operatorname{Res}^{+}+\log \mathrm{Ex}\right]$} & 0.007 & 0.114 & 0.131 & $0.099 * * *$ & $0.146^{* *}$ & $0.161 * * *$ & $0.094 * * *$ \\
\hline & $(0.005)$ & $\begin{array}{l}(0.078) \\
\end{array}$ & $(0.078)$ & $(0.024)$ & $(0.069)$ & $(0.035)$ & $(0.034)$ \\
\hline \multirow[t]{2}{*}{ German mark } & & & & -0.029 & $0.172 *$ & & \\
\hline & & & & $(0.053)$ & $(0.093)$ & & \\
\hline \multirow[t]{2}{*}{ Euro } & & & & & & $0.405 * * *$ & 0.054 \\
\hline & & & & & & $(0.083)$ & $(0.134)$ \\
\hline \multirow[t]{2}{*}{+ Constant } & $-0.012 * *$ & $-0.011 *$ & $-0.005^{*}$ & -0.000 & -0.003 & -0.000 & 0.000 \\
\hline & $(0.004)$ & $(0.006)$ & $(0.003)$ & $(0.001)$ & $(0.002)$ & $(0.002)$ & $(0.001)$ \\
\hline Observations & 40 & 48 & 48 & 48 & 36 & 48 & 41 \\
\hline R-squared & 0.567 & 0.447 & 0.728 & 0.948 & 0.717 & 0.786 & 0.747 \\
\hline GBP & 0.075 & 0.364 & 0.108 & 0.117 & -0.093 & -0.156 & 0.367 \\
\hline
\end{tabular}




\subsection{Australian dollar (aud)}

\begin{tabular}{|c|c|c|c|c|}
\hline & $(1)$ & $(2)$ & (3) & (4) \\
\hline & aud 92-95 & $96-99$ & $00-03$ & $04-07$ \\
\hline \multirow[t]{2}{*}{ JPY } & -0.008 & 0.210 & $0.250 * *$ & 0.160 \\
\hline & $(0.102)$ & $(0.135)$ & $(0.104)$ & $(0.150)$ \\
\hline \multirow[t]{2}{*}{ USD } & $1.036^{* * *}$ & $0.676^{* * *}$ & 0.294 & 0.181 \\
\hline & $(0.070)$ & $(0.236)$ & $(0.201)$ & $(0.142)$ \\
\hline \multirow[t]{2}{*}{ German mark } & -0.171 & -0.140 & & \\
\hline & $(0.141)$ & $(0.180)$ & & \\
\hline \multirow[t]{2}{*}{$\Delta[\log \operatorname{Res}+\log \mathrm{Ex}]$} & $0.242 * * *$ & 0.062 & $0.175 * * *$ & 0.047 \\
\hline & $(0.043)$ & $(0.070)$ & $(0.043)$ & $(0.040)$ \\
\hline \multirow[t]{2}{*}{ EUR } & & & $0.554 * * *$ & 0.107 \\
\hline & & & $(0.123)$ & $(0.247)$ \\
\hline \multirow[t]{2}{*}{ Constant } & 0.002 & -0.006 & -0.001 & 0.001 \\
\hline & $(0.002)$ & $(0.005)$ & $(0.003)$ & $(0.003)$ \\
\hline Observations & 48 & 36 & 48 & 42 \\
\hline R-squared & 0.833 & 0.327 & 0.538 & 0.171 \\
\hline GBP & 0.143 & 0.254 & -0.098 & 0.552 \\
\hline
\end{tabular}

\subsection{Canadian dollar (cad)}

\begin{tabular}{|l|l|l|l|l|l|}
\hline & $(1)$ & $(2)$ & $(3)$ & $(4)$ & $(5)$ \\
\hline & cad 90-93 & $94-97$ & $98-01$ & $02-05$ & $06-09$ \\
\hline JPY & 0.046 & 0.018 & 0.035 & $0.324^{* * *}$ & -0.162 \\
\hline & $(0.058)$ & $(0.080)$ & $(0.076)$ & $(0.092)$ & $(0.283)$ \\
\hline USD & $0.902^{* * *}$ & $0.966^{* * *}$ & 0.321 & $0.449 * * *$ & $0.543^{*}$ \\
\hline & $(0.049)$ & $(0.095)$ & $(0.322)$ & $(0.112)$ & $(0.282)$ \\
\hline German mark & 0.007 & 0.018 & 0.101 & & \\
\hline & $(0.066)$ & $(0.075)$ & $(0.313)$ & & $0.366^{* * *}$ \\
\hline$\Delta[\operatorname{logRes}+\operatorname{logEx}]$ & $0.106^{* * *}$ & $0.067^{* * *}$ & $0.124^{* *}$ & $0.401^{* *}$ \\
\hline & $(0.014)$ & $(0.024)$ & $(0.034)$ & $(0.112)$ & $(0.129)$ \\
\hline EUR & & & & $0.337^{*}$ & 0.189 \\
\hline & & & & $(0.179)$ & $(0.522)$ \\
\hline Constant & $-0.002^{*}$ & -0.002 & -0.008 & 0.004 & -0.005 \\
\hline & $(0.001)$ & $(0.002)$ & $(0.006)$ & $(0.002)$ & $(0.005)$ \\
\hline Observations & 48 & 48 & 8 & 48 & 14 \\
\hline R-squared & 0.958 & 0.790 & 0.776 & 0.708 & 0.684 \\
\hline GBP & 0.046 & -0.002 & 0.543 & -0.110 & 0.430 \\
\hline
\end{tabular}

\subsection{Mexico (mxn)}

\begin{tabular}{|l|l|l|l|l|l|l|l|}
\hline & $(1)$ & $(2)$ & $(3)$ & $(4)$ & $(5)$ & $(6)$ & $(7)$ \\
\hline & mxn 80-83 & $84-87$ & $88-91$ & $92-95$ & $96-99$ & $00-03$ & $04-07$ \\
\hline JPY & -0.321 & -0.168 & 0.049 & $0.497^{* *}$ & 0.077 & 0.098 & $0.179^{* *}$ \\
\hline & $(0.609)$ & $(0.248)$ & $(0.036)$ & $(0.205)$ & $(0.057)$ & $(0.100)$ & $(0.075)$ \\
\hline USD & $1.210^{*}$ & $1.358^{* * *}$ & $0.988^{* * *}$ & $0.702^{* * *}$ & $1.110^{* * *}$ & $0.795^{* * *}$ & $0.617^{* * *}$ \\
\hline & $(0.675)$ & $(0.154)$ & $(0.026)$ & $(0.226)$ & $(0.259)$ & $(0.146)$ & $(0.134)$ \\
\hline French franc & -0.378 & -0.189 & -0.062 & & & & \\
\hline & $(0.592)$ & $(0.239)$ & $(0.047)$ & & & & \\
\hline$\Delta[\operatorname{logRes}+\operatorname{logEx}]$ & $0.212^{*}$ & $0.132^{* *}$ & -0.005 & $0.212^{* * *}$ & $0.335^{* * *}$ & $0.398^{* * *}$ & $0.336^{* * *}$ \\
\hline & $(0.124)$ & $(0.061)$ & $(0.004)$ & $(0.074)$ & $(0.086)$ & $(0.094)$ & $(0.090)$ \\
\hline
\end{tabular}




\begin{tabular}{|l|l|l|l|l|l|l|l|}
\hline German mark & & & & $-0.715^{*}$ & -0.073 & & \\
\hline & & & & $(0.411)$ & $(0.134)$ & & \\
\hline Euro & & & & & & 0.229 & -0.105 \\
\hline & & & & & & $(0.148)$ & $(0.230)$ \\
\hline Constant & $-0.036^{* *}$ & $-0.047^{* * *}$ & $-0.007^{* * *}$ & $-0.014^{* *}$ & $-0.011^{* * *}$ & $-0.007^{* *}$ & -0.001 \\
\hline & $(0.017)$ & $(0.004)$ & $(0.001)$ & $(0.006)$ & $(0.003)$ & $(0.003)$ & $(0.002)$ \\
\hline Observations & 46 & 48 & 48 & 48 & 36 & 48 & 42 \\
\hline R-squared & 0.307 & 0.758 & 0.979 & 0.683 & 0.805 & 0.774 & 0.721 \\
\hline GBP & 0.489 & -0.001 & 0.026 & 0.516 & -0.113 & -0.122 & 0.310 \\
\hline
\end{tabular}

\subsection{Indonesia (idr)}

\begin{tabular}{|l|l|l|l|l|}
\hline & $(1)$ & $(2)$ & $(3)$ & $(4)$ \\
\hline & idr 92-95 & $96-99$ & $00-03$ & $04-07$ \\
\hline & $0.056^{*}$ & $0.298^{* *}$ & 0.111 & -0.207 \\
\hline & $(0.029)$ & $(0.135)$ & $(0.152)$ & $(0.132)$ \\
\hline & $1.475^{* * *}$ & -0.118 & $-2,355.834$ & 0.213 \\
\hline KRW & $(0.273)$ & $(0.666)$ & $(4,298.661)$ & $(0.287)$ \\
\hline & $-0.097^{*}$ & $-0.286^{* * *}$ & 0.000 & 0.016 \\
\hline SGD & $(0.048)$ & $(0.074)$ & $(0.126)$ & $(0.163)$ \\
\hline & -0.002 & -0.090 & $0.657^{* *}$ & $0.660^{*}$ \\
\hline AUD & $(0.072)$ & $(0.783)$ & $(0.263)$ & $(0.331)$ \\
\hline & 0.011 & -0.165 & 0.051 & $0.287^{* *}$ \\
\hline MYR & $(0.015)$ & $(0.257)$ & $(0.125)$ & $(0.138)$ \\
\hline & -0.006 & 0.286 & $2,355.762$ & -0.017 \\
\hline THB & $(0.012)$ & $(0.372)$ & $(4,298.726)$ & $(0.330)$ \\
\hline & -0.486 & 0.164 & -0.164 & $0.584^{* * *}$ \\
\hline Germany mark & $(0.299)$ & $(0.313)$ & $(0.232)$ & $(0.177)$ \\
\hline & $0.042^{*}$ & 0.345 & & \\
\hline$\Delta[\operatorname{logRes}+\operatorname{logEx}]$ & $(0.021)$ & $(0.397)$ & & $0.226^{* * *}$ \\
\hline & -0.006 & $0.892^{* * *}$ & $0.736^{* * *}$ & $(0.041)$ \\
\hline Euro & $(0.006)$ & $(0.065)$ & $(0.117)$ & $-0.314^{*}$ \\
\hline & & & $0.388^{* *}$ & $(0.158)$ \\
\hline Constant & & & $(0.160)$ & $-0.006^{* *}$ \\
\hline & $-0.003^{* * *}$ & $-0.017^{*}$ & -0.005 & $(0.002)$ \\
\hline Observations & $(0.000)$ & $(0.009)$ & $(0.003)$ & 41 \\
\hline R-squared & 48 & 36 & 48 & 0.892 \\
\hline GBP & 0.998 & 0.952 & 0.875 & -0.222 \\
\hline & 0.008 & 0.568 & 0.030 & \\
\hline & & & \\
\hline & & & \\
\hline & & & \\
\hline & & & \\
\hline
\end{tabular}

* Statistically significant at .10 level

** Statistically significant at $\mathbf{0 5}$ level $* * *$ Statistically significant at $\mathbf{0 1}$ level 
Table 3: Estimating the De Facto Exchange Rate Regime with commodity prices as instrumental variables for the change in EMP in the case of commodity exporters $(01 / 1980-06 / 2007) \quad$ numeraire currency $=$ SDR

IV: average of prices of semiconductors and tin

\begin{tabular}{|l|l|l|l|l|}
\hline & $(1)$ & $(2)$ & $(3)$ & $(4)$ \\
\hline & myr-IV 92-95 & $96-99$ & $00-03$ & $04-07$ \\
\hline$\Delta[\log R e s+\log E x]$ & 0.092 & -0.154 & -0.000 & 0.253 \\
\hline & $(0.060)$ & $(0.571)$ & $(0.000)$ & $(0.150)$ \\
\hline JPY & -0.137 & -0.180 & -0.000 & -0.033 \\
\hline & $(0.195)$ & $(0.210)$ & $(0.000)$ & $(0.082)$ \\
\hline USD & -0.833 & -0.194 & $1.000^{* * *}$ & $0.493^{* * *}$ \\
\hline & $(2.205)$ & $(0.627)$ & $(0.000)$ & $(0.168)$ \\
\hline KRW & 0.042 & -0.120 & 0.000 & -0.086 \\
\hline SGD & $(0.380)$ & $(0.109)$ & $(0.000)$ & $(0.097)$ \\
\hline & $0.858^{*}$ & $1.222^{*}$ & -0.000 & $0.463^{* *}$ \\
\hline AUD & $(0.442)$ & $(0.670)$ & $(0.000)$ & $(0.192)$ \\
\hline & -0.110 & 0.029 & 0.000 & -0.028 \\
\hline THB & $(0.149)$ & $(0.328)$ & $(0.000)$ & $(0.084)$ \\
\hline & 1.262 & 0.542 & 0.000 & 0.029 \\
\hline German mark & $(2.428)$ & $(0.482)$ & $(0.000)$ & $(0.094)$ \\
\hline & -0.116 & -0.206 & & \\
\hline Euro & $(0.196)$ & $(0.352)$ & & 0.103 \\
\hline & & & -0.000 & $(0.167)$ \\
\hline Constant & -0.002 & & $(0.000)$ & -0.004 \\
\hline & $(0.003)$ & -0.004 & 0.000 & $(0.003)$ \\
\hline Observations & 48 & $(0.007)$ & $(0.000)$ & 40 \\
\hline R-squared & 0.798 & 36 & 48 & 0.903 \\
\hline GBP & 0.034 & 0.784 & 1.000 & 0.059 \\
\hline
\end{tabular}

3.4 Chile (clp)

Instrumental Variable : Price of copper

\begin{tabular}{|c|c|c|c|c|c|c|c|}
\hline & (1) & (2) & (3) & (4) & (5) & (6) & (7) \\
\hline & $\begin{array}{l}\text { clp-IV 80- } \\
83\end{array}$ & $84-87$ & $88-91$ & $92-95$ & $96-99$ & $00-03$ & $04-07$ \\
\hline \multirow{2}{*}{$\Delta[\log R e s+\log E x]$} & $0.359 * * *$ & 1.171 & 0.435 & $0.333^{*}$ & $0.291 * * *$ & 0.310 & -11.766 \\
\hline & $\begin{array}{l}(0.098) \\
\end{array}$ & $(1.113)$ & $(1.296)$ & $(0.166)$ & $(0.085)$ & $(0.758)$ & $(416.229)$ \\
\hline \multirow{2}{*}{ JPY } & -0.043 & 0.883 & 0.344 & $0.207^{* * *}$ & $0.116^{* * *}$ & 0.113 & -5.265 \\
\hline & $(0.126)$ & $(0.574)$ & $(0.955)$ & $\begin{array}{l}(0.059) \\
\end{array}$ & $(0.034)$ & $(0.190)$ & (179.614) \\
\hline \multirow[t]{2}{*}{ USD } & $0.534 * * *$ & -0.731 & 0.422 & $0.691^{* * *}$ & $0.843 * * *$ & 0.587 & 10.803 \\
\hline & $(0.190)$ & $(2.242)$ & $(1.724)$ & $(0.135)$ & $(0.088)$ & $(0.507)$ & (348.039) \\
\hline \multirow[t]{2}{*}{ French franc } & $0.483^{* *}$ & 0.576 & 0.106 & & & & \\
\hline & $(0.210)$ & $(1.318)$ & $(1.102)$ & & & & \\
\hline \multirow[t]{2}{*}{ German mark } & & & & -0.006 & $0.131^{*}$ & & \\
\hline & & & & $(0.113)$ & $(0.064)$ & & \\
\hline EUR & & & & & & 0.080 & -4.345 \\
\hline
\end{tabular}




\begin{tabular}{|l|l|l|l|l|l|l|l|}
\hline & & & & & & $(0.332)$ & $(173.089)$ \\
\hline Constant & -0.004 & -0.005 & -0.014 & $-0.006^{* * *}$ & $-0.004^{* *}$ & -0.002 & 0.037 \\
\hline & $(0.004)$ & $(0.018)$ & $(0.014)$ & $(0.002)$ & $(0.001)$ & $(0.003)$ & $(1.185)$ \\
\hline Observations & 46 & 48 & 48 & 48 & 36 & 48 & 41 \\
\hline R-squared & 0.566 & 0.289 & 0.619 & 0.905 & 0.902 & 0.628 & \\
\hline GBP & 0.025 & 0.272 & 0.128 & 0.108 & -0.089 & 0.220 & -0.192 \\
\hline
\end{tabular}

\section{IV: Price of oil}

\subsection{Kuwait (kwd)}

\begin{tabular}{|c|c|c|c|c|c|c|c|}
\hline & $(1)$ & (2) & (3) & (4) & $(5)$ & $(6)$ & $(7)$ \\
\hline & $\begin{array}{l}\text { kwd-IV 80- } \\
83\end{array}$ & $84-87$ & $88-91$ & $92-95$ & $96-99$ & $00-03$ & $04-07$ \\
\hline \multirow[t]{2}{*}{$\Delta[\log \operatorname{Res}+\log E x]$} & -0.019 & 0.224 & 0.030 & -0.053 & -0.123 & 0.095 & 0.028 \\
\hline & $(0.029)$ & $(0.392)$ & $(0.033)$ & $(0.073)$ & $(0.649)$ & $(0.253)$ & $(0.046)$ \\
\hline \multirow[t]{2}{*}{ JPY } & $0.079 * * *$ & 0.305 & $0.126^{*}$ & 0.041 & 0.007 & 0.085 & 0.038 \\
\hline & $(0.016)$ & $(0.227)$ & $(0.070)$ & $(0.041)$ & $(0.225)$ & $(0.089)$ & $(0.044)$ \\
\hline \multirow[t]{2}{*}{ USD } & $0.814 * * *$ & 0.435 & $0.637 * * *$ & $0.834 * * *$ & $0.945^{*}$ & $0.723 * *$ & $0.972 * * *$ \\
\hline & $(0.031)$ & $(0.394)$ & $(0.044)$ & $(0.095)$ & $(0.521)$ & $(0.317)$ & $(0.059)$ \\
\hline \multirow[t]{2}{*}{ French franc } & 0.032 & 0.270 & $0.155^{* *}$ & & & & \\
\hline & $(0.029)$ & $(0.201)$ & $(0.063)$ & & & & \\
\hline \multirow[t]{2}{*}{ German mark } & & & & 0.065 & 0.001 & & \\
\hline & & & & $(0.073)$ & $(0.290)$ & & \\
\hline \multirow[t]{2}{*}{ Euro } & & & & & & 0.084 & -0.062 \\
\hline & & & & & & $(0.110)$ & $(0.052)$ \\
\hline \multirow[t]{2}{*}{ Constant } & 0.000 & -0.001 & -0.001 & -0.001 & 0.000 & -0.001 & -0.000 \\
\hline & $(0.001)$ & $(0.003)$ & $(0.001)$ & $(0.001)$ & $(0.002)$ & $(0.002)$ & $(0.001)$ \\
\hline Observations & 46 & 48 & 39 & 48 & 36 & 48 & 41 \\
\hline R-squared & 0.980 & 0.755 & 0.953 & 0.937 & 0.873 & 0.931 & 0.980 \\
\hline GBP & 0.075 & -0.009 & 0.083 & 0.060 & 0.048 & 0.107 & 0.052 \\
\hline
\end{tabular}

\subsection{Norway (nok)}

\section{IV: oil price}

\begin{tabular}{|l|l|l|l|l|l|l|l|}
\hline & $(1)$ & $(2)$ & $(3)$ & $(4)$ & $(5)$ & $(6)$ & $(7)$ \\
\hline & $\begin{array}{l}\text { nok-IV 80- } \\
\text { 83 }\end{array}$ & $84-87$ & $88-91$ & $92-95$ & $96-99$ & $00-03$ & $04-07$ \\
\hline$\Delta[\operatorname{logRes}+\operatorname{logEx}]$ & -0.219 & 0.097 & 0.081 & -0.182 & $0.219^{*}$ & 30.036 & 0.206 \\
\hline & $(0.469)$ & $(0.090)$ & $(0.079)$ & $(0.374)$ & $(0.113)$ & $(2,045.207)$ & $(0.471)$ \\
\hline JPY & 0.075 & $0.117^{*}$ & 0.018 & -0.121 & 0.001 & 14.527 & 0.155 \\
\hline & $(0.166)$ & $(0.066)$ & $(0.058)$ & $(0.150)$ & $(0.077)$ & $(983.036)$ & $(0.205)$ \\
\hline USD & 0.178 & 0.065 & $0.179^{* * *}$ & -0.012 & $0.279^{*}$ & 7.677 & -0.066 \\
\hline & $(0.350)$ & $(0.068)$ & $(0.035)$ & $(0.235)$ & $(0.161)$ & $(523.059)$ & $(0.161)$ \\
\hline French franc & $0.334^{* * *}$ & $0.699^{* * *}$ & $0.578^{* * *}$ & & & & \\
\hline & $(0.115)$ & $(0.118)$ & $(0.066)$ & & & & \\
\hline German mark & & & & $0.865^{* * *}$ & $0.779^{* * *}$ & & $(0.134)$ \\
\hline & & & & & & -29.766 & $1.095^{* * *}$ \\
\hline EUR & & & & & & $(2,086.199)$ & $(0.345)$ \\
\hline & & & & & & -0.155 & -0.001 \\
\hline Constant & 0.001 & $-0.005^{*}$ & 0.001 & 0.001 & -0.000 & $(10.623)$ & $(0.004)$ \\
\hline & $(0.008)$ & $(0.003)$ & $(0.001)$ & $(0.002)$ & $(0.003)$ & 48 & 41 \\
\hline Observations & 46 & 48 & 48 & 48 & 36 & & 0.493 \\
\hline R-squared & 0.327 & 0.767 & 0.780 & 0.203 & 0.610 & & -0.184 \\
\hline GBP & 0.412 & 0.118 & 0.225 & 0.269 & -0.059 & 8.561 & \\
\hline
\end{tabular}




\subsection{Papua New Guinea kina (png)}

\section{IV: average price of gold, copper, oil, gas and timber}

\begin{tabular}{|l|l|l|l|l|}
\hline & $(1)$ & $(2)$ & $(3)$ & $(4)$ \\
\hline & png-IV 92-95 & $96-99$ & $00-03$ & $04-07$ \\
\hline$\Delta[\log R e s+\log E x]$ & -0.001 & 0.139 & 0.028 & -0.042 \\
\hline & $(0.028)$ & $(0.179)$ & $(0.888)$ & $(0.035)$ \\
\hline JPY & 0.193 & $0.577^{* *}$ & 0.759 & 0.009 \\
\hline & $(0.325)$ & $(0.248)$ & $(1.952)$ & $(0.056)$ \\
\hline USD & 2.019 & $1.185^{* * *}$ & 1.463 & $1.243^{* * *}$ \\
\hline & $(2.543)$ & $(0.360)$ & $(2.037)$ & $(0.150)$ \\
\hline KRW & $-1.264^{* *}$ & -0.047 & -0.405 & -0.023 \\
\hline & $(0.502)$ & $(0.099)$ & $(1.553)$ & $(0.110)$ \\
\hline SGD & -0.457 & -0.885 & -0.509 & 0.047 \\
\hline & $(0.666)$ & $(0.615)$ & $(2.016)$ & $(0.229)$ \\
\hline AUD & $0.311^{* *}$ & 0.054 & 0.300 & -0.042 \\
\hline & $(0.141)$ & $(0.316)$ & $(0.894)$ & $(0.061)$ \\
\hline MYR & -0.003 & 0.356 & 0.000 & $-0.351^{* *}$ \\
\hline & $(0.213)$ & $0.258)$ & $(0.000)$ & $(0.158)$ \\
\hline THB & 0.205 & 0.034 & -0.335 & 0.014 \\
\hline & $(2.862)$ & $(0.182)$ & $(0.745)$ & $(0.083)$ \\
\hline German mark & 0.134 & -0.229 & & \\
\hline & $(0.329)$ & $(0.292)$ & & -0.005 \\
\hline Euro & & & 0.498 & $(0.094)$ \\
\hline & & & $0.578)$ & $0.004^{* *}$ \\
\hline Constant & $-0.008^{* *}$ & -0.009 & -0.007 & $(0.002)$ \\
\hline & $(0.004)$ & $(0.006)$ & $(0.012)$ & 41 \\
\hline Observations & 47 & 36 & 48 & 0.941 \\
\hline R-squared & 0.715 & 0.533 & 0.433 & 0.108 \\
\hline GBP & -0.138 & -0.045 & -0.770 & \\
\hline & & & & \\
\hline
\end{tabular}

\subsection{Russia (rub)}

\section{IV: Price of oil}

\begin{tabular}{|c|c|c|c|c|}
\hline & (1) & (2) & (3) & (4) \\
\hline & rub-IV 92-95 & $96-99$ & $00-03$ & 04-07 \\
\hline \multirow{2}{*}{$\Delta[\log \operatorname{Res}+\log \mathrm{Ex}]$} & -0.243 & $0.661^{*}$ & $0.125 * *$ & -0.066 \\
\hline & $(0.280)$ & $(0.353)$ & $(0.047)$ & $(0.552)$ \\
\hline \multirow[t]{2}{*}{ JPY } & -0.126 & -0.381 & 0.106 & 0.121 \\
\hline & $(0.496)$ & $(0.411)$ & $(0.071)$ & $(0.117)$ \\
\hline \multirow[t]{2}{*}{ USD } & 1.248 & $2.353 * *$ & $0.755^{* * *}$ & $0.542 * * *$ \\
\hline & $(1.278)$ & $(0.921)$ & $(0.083)$ & $(0.197)$ \\
\hline \multirow[t]{2}{*}{ German mark } & -1.444 & -0.059 & & \\
\hline & $(0.794)$ & $(1.162)$ & & \\
\hline \multirow[t]{2}{*}{ Euro } & & & 0.067 & 0.104 \\
\hline & & & $(0.072)$ & $(0.373)$ \\
\hline \multirow[t]{2}{*}{ Constant } & 0.032 & -0.006 & $-0.007 * * *$ & 0.006 \\
\hline & $(0.051)$ & $(0.021)$ & $(0.003)$ & $(0.024)$ \\
\hline Observations & 11 & 36 & 48 & 41 \\
\hline R-squared & 0.040 & 0.399 & 0.860 & 0.728 \\
\hline GBP & 1.322 & -0.912 & 0.072 & 0.233 \\
\hline
\end{tabular}




\subsection{Thailand (thb)}

IV: rice

\begin{tabular}{|c|c|c|c|c|c|c|c|}
\hline & $(1)$ & $(2)$ & (3) & $(4)$ & $(5)$ & $(6)$ & (7) \\
\hline & $\begin{array}{l}\text { thb-IV 80- } \\
83\end{array}$ & $84-87$ & $88-91$ & $92-95$ & $96-99$ & $00-03$ & 04-07 \\
\hline \multirow{2}{*}{$\Delta[\log \mathrm{Res}+\log \mathrm{Ex}]$} & 0.716 & 0.483 & 0.218 & -0.860 & 0.235 & 0.596 & $0.605^{* * *}$ \\
\hline & $(1.159)$ & $(0.957)$ & $(2.012)$ & $(11.002)$ & $(0.258)$ & $(0.534)$ & $(0.178)$ \\
\hline \multirow[t]{2}{*}{ JPY } & -0.289 & 0.072 & 0.237 & -0.153 & -0.007 & 0.094 & 0.069 \\
\hline & $(0.744)$ & $(0.167)$ & (1.099) & $(3.254)$ & $(0.227)$ & $(0.087)$ & $(0.077)$ \\
\hline \multirow[t]{2}{*}{ USD } & 1.459 & 1.094 & $0.734 * * *$ & 1.497 & -0.515 & $0.582 *$ & 0.419 \\
\hline & $(1.255)$ & $(1.246)$ & $(0.224)$ & $(7.833)$ & $(0.426)$ & $(0.289)$ & $(0.286)$ \\
\hline \multirow[t]{2}{*}{ KRW } & 0.694 & 0.072 & -0.110 & -0.444 & 0.117 & 0.017 & 0.065 \\
\hline & $(1.752)$ & $(0.760)$ & $(1.224)$ & $(4.436)$ & $(0.101)$ & $(0.147)$ & $(0.093)$ \\
\hline \multirow[t]{2}{*}{ SGD } & 0.498 & -0.081 & -0.246 & 0.680 & 0.605 & -0.109 & 0.194 \\
\hline & $(1.553)$ & $(0.694)$ & $(2.538)$ & $(8.331)$ & $(0.677)$ & $(0.395)$ & $(0.252)$ \\
\hline \multirow[t]{2}{*}{ AUD } & -0.011 & -0.264 & 0.028 & -0.245 & -0.265 & 0.075 & -0.023 \\
\hline & $(0.355)$ & $(0.514)$ & $(0.133)$ & $(3.287)$ & $(0.209)$ & $(0.107)$ & $(0.080)$ \\
\hline \multirow[t]{2}{*}{ MYR } & -2.301 & -0.651 & 0.151 & 0.312 & $0.578 * *$ & 0.000 & -0.176 \\
\hline & $(4.483)$ & $(1.358)$ & (1.393) & (3.972) & $(0.250)$ & $(0.000)$ & $(0.305)$ \\
\hline \multirow[t]{2}{*}{ French franc } & 0.181 & 0.471 & 0.192 & & & & \\
\hline & $(0.462)$ & $(0.859)$ & $(1.278)$ & & & & \\
\hline \multirow[t]{2}{*}{ German mark } & & & & -0.505 & 0.361 & & \\
\hline & & & & $(7.240)$ & $(0.346)$ & & \\
\hline \multirow[t]{2}{*}{ Euro } & & & & & & 0.373 & 0.165 \\
\hline & & & & & & $(0.310)$ & $(0.107)$ \\
\hline \multirow[t]{2}{*}{ Constant } & 0.007 & -0.013 & -0.005 & 0.010 & 0.003 & -0.003 & $-0.007 * * *$ \\
\hline & $(0.020)$ & $(0.022)$ & $(0.046)$ & $(0.128)$ & $(0.006)$ & $(0.002)$ & $(0.002)$ \\
\hline Observations & 46 & 48 & 48 & 48 & 36 & 48 & 41 \\
\hline GBP & 0.769 & 0.286 & 0.014 & -0.141 & 0.127 & -0.032 & 0.286 \\
\hline
\end{tabular}

\subsection{Western Samoa tala (Wst)}

\section{IV: Price of coconuts}

\begin{tabular}{|c|c|c|c|c|c|c|c|}
\hline & (1) & (2) & (3) & (4) & $(5)$ & (6) & (7) \\
\hline & $\begin{array}{l}\text { wst-IV 80- } \\
83\end{array}$ & $84-87$ & $88-91$ & $92-95$ & $96-99$ & $00-03$ & 04-07 \\
\hline \multirow[t]{2}{*}{$\Delta[\log \operatorname{Res}+\log E x]$} & -7.677 & 0.288 & 0.257 & 0.262 & 0.795 & 1.539 & 0.225 \\
\hline & $(1,794.239)$ & $(0.262)$ & $(0.460)$ & $(0.167)$ & $(0.596)$ & $(4.821)$ & $(0.228)$ \\
\hline \multirow[t]{2}{*}{ JPY } & -16.820 & 0.006 & $0.398 * *$ & $0.244 * *$ & $0.402^{*}$ & 0.366 & 0.046 \\
\hline & $(3,987.521)$ & $(0.234)$ & $(0.179)$ & $(0.111)$ & $(0.198)$ & $(0.950)$ & $(0.096)$ \\
\hline \multirow[t]{2}{*}{ USD } & -33.465 & 0.337 & 0.414 & $0.609 * * *$ & 0.010 & 1.387 & $0.540 * * *$ \\
\hline & $(7,961.609)$ & $(0.205)$ & $(0.490)$ & $(0.176)$ & $(0.751)$ & $(2.984)$ & $(0.082)$ \\
\hline \multirow[t]{2}{*}{ French franc } & 33.903 & 0.207 & 0.247 & & & & \\
\hline & $(7,902.798)$ & $(0.291)$ & $(0.996)$ & & & & \\
\hline \multirow[t]{2}{*}{ German mark } & & & & 0.062 & 0.274 & & \\
\hline & & & & $(0.125)$ & $(0.269)$ & & \\
\hline \multirow[t]{2}{*}{ Euro } & & & & & & 0.335 & 0.073 \\
\hline & & & & & & $(0.605)$ & $(0.149)$ \\
\hline \multirow[t]{2}{*}{ Constant } & 0.910 & -0.014 & -0.006 & 0.000 & -0.004 & -0.002 & -0.000 \\
\hline & $(215.500)$ & $(0.009)$ & $(0.006)$ & $(0.002)$ & $(0.006)$ & $(0.013)$ & $(0.002)$ \\
\hline Observations & 40 & 48 & 48 & 48 & 36 & 48 & 41 \\
\hline GBP & 17.382 & 0.450 & -0.059 & 0.084 & 0.313 & -1.089 & 0.342 \\
\hline R-squared & & 0.238 & 0.660 & 0.889 & & & 0.540 \\
\hline
\end{tabular}




\subsection{Australia (aud)}

IV: world commodity price index

\begin{tabular}{|l|l|l|l|l|}
\hline & $(1)$ & $(2)$ & $(3)$ & $(4)$ \\
\hline & aud-IV 92-95 & $96-99$ & $00-03$ & $04-07$ \\
\hline$\Delta[\operatorname{logRes}+\operatorname{logEx}]$ & $0.295^{* *}$ & 0.380 & 0.632 & 0.333 \\
\hline & $(0.122)$ & $(0.471)$ & $(1.034)$ & $(0.905)$ \\
\hline JPY & 0.012 & 0.202 & 0.101 & 0.261 \\
\hline & $(0.109)$ & $(0.131)$ & $(0.400)$ & $(0.372)$ \\
\hline USD & $1.010 * * *$ & 0.561 & 0.768 & 0.263 \\
\hline & $(0.095)$ & $(0.342)$ & $(1.146)$ & $(0.353)$ \\
\hline German mark & -0.144 & -0.058 & & \\
\hline & $(0.153)$ & $(0.392)$ & & 0.446 \\
\hline Euro & & & 0.507 & $(1.177)$ \\
\hline & & & $(0.347)$ & -0.004 \\
\hline Constant & 0.003 & -0.007 & -0.004 & $(0.016)$ \\
\hline & $(0.003)$ & $(0.006)$ & $(0.011)$ & 41 \\
\hline Observations & 48 & 36 & 48 & \\
\hline R-squared & 0.829 & & & 0.030 \\
\hline GBP & 0.123 & 0.294 & -0.375 & \\
\hline
\end{tabular}

Notes:

1. Use the level of commodity prices as instrumental variables for the change in EMP

2. Commodity prices have been converted to SDR

3. The commodity prices have been deflated by the weighted world CPI:

we calculate the weighted CPI by using the weights and currencies that are used to define SDR, and have adjusted their weights according to their evolution since 1980

4. Data source: IMF International financial statistics

5. Indices of Unit Values (Prices) In Terms of US Dollars: 2000=100

\subsection{Canadian dollar (cad)}

IV: world commodity price index

\begin{tabular}{|l|l|l|l|l|l|}
\hline & $(1)$ & $(2)$ & $(3)$ & $(4)$ & $(5)$ \\
\hline & cad-IV 90-93 & $94-97$ & $98-01$ & $02-05$ & $06-09$ \\
\hline$\Delta[\operatorname{logRes}+\operatorname{logEx}]$ & 0.288 & 0.292 & 0.190 & 0.633 & 1.333 \\
\hline & $(0.263)$ & $(0.929)$ & $(0.108)$ & $(0.674)$ & $(0.960)$ \\
\hline JPY & 0.236 & 0.055 & 0.073 & $0.323^{* * *}$ & -0.215 \\
\hline & $(0.300)$ & $(0.156)$ & $(0.157)$ & $(0.105)$ & $(0.841)$ \\
\hline USD & $0.672^{*}$ & 0.802 & 0.225 & 0.320 & -0.038 \\
\hline & $(0.359)$ & $(0.719)$ & $(0.423)$ & $(0.321)$ & $(1.036)$ \\
\hline German mark & 0.291 & 0.040 & 0.051 & & \\
\hline Euro & $(0.437)$ & $(0.189)$ & $(0.394)$ & & $0.331^{*}$ \\
\hline & & & & $(0.183)$ & -0.159 \\
\hline Constant & -0.002 & -0.005 & -0.008 & 0.003 & $(0.713)$ \\
\hline & $(0.003)$ & $(0.016)$ & $(0.007)$ & $(0.002)$ & $(0.017$ \\
\hline Observations & 48 & 48 & 8 & 48 & $0.019)$ \\
\hline R-squared & 0.835 & 0.303 & 0.626 & 0.627 & 13 \\
\hline
\end{tabular}




\subsection{Mexico (mxn)}

IV: oil price

\begin{tabular}{|c|c|c|c|c|c|c|c|}
\hline & (1) & (2) & (3) & (4) & (5) & (6) & (7) \\
\hline & $\begin{array}{l}\text { mxn-IV } \\
80-83\end{array}$ & $84-87$ & $88-91$ & $92-95$ & 96-99 & 00-03 & $04-07$ \\
\hline \multirow{2}{*}{$\Delta[\log \operatorname{Res}+\log \mathrm{Ex}]$} & 2.300 & 1.056 & -0.050 & 0.573 & 0.174 & 1.069 & 0.389 \\
\hline & $(4.951)$ & $(1.249)$ & $(0.032)$ & $(0.479)$ & $(0.274)$ & $(1.552)$ & $(0.754)$ \\
\hline \multirow[t]{2}{*}{ JPY } & 1.250 & 0.629 & 0.095 & 0.613 & 0.065 & 0.557 & 0.193 \\
\hline & $(3.833)$ & $(1.143)$ & $(0.097)$ & $(0.506)$ & $(0.064)$ & $(1.055)$ & $(0.256)$ \\
\hline \multirow[t]{2}{*}{ USD } & 0.504 & -0.418 & $0.996 * * *$ & 0.143 & $1.314 * * *$ & -0.109 & 0.556 \\
\hline & $(4.467)$ & $(2.482)$ & $(0.039)$ & $(0.811)$ & $(0.388)$ & $(2.031)$ & $(0.903)$ \\
\hline \multirow[t]{2}{*}{ French franc } & 0.618 & 1.492 & -0.117 & & & & \\
\hline & $(6.156)$ & $(2.760)$ & $(0.090)$ & & & & \\
\hline \multirow[t]{2}{*}{ German mark } & & & & -0.341 & -0.174 & & \\
\hline & & & & $(0.928)$ & $(0.194)$ & & \\
\hline \multirow[t]{2}{*}{ Euro } & & & & & & 0.808 & -0.050 \\
\hline & & & & & & $(1.342)$ & $(0.856)$ \\
\hline \multirow{2}{*}{ Constant } & -0.003 & -0.027 & $-0.007 * * *$ & -0.006 & -0.010 & -0.013 & -0.002 \\
\hline & $(0.130)$ & $(0.027)$ & $(0.001)$ & $(0.010)$ & $(0.006)$ & $(0.015)$ & $(0.004)$ \\
\hline Observations & 46 & 48 & 48 & 48 & 36 & 48 & 41 \\
\hline GBP & -1.373 & -0.703 & 0.027 & 0.584 & -0.205 & -0.256 & 0.301 \\
\hline R-squared & & & 0.950 & & 0.754 & 0.297 & 0.714 \\
\hline
\end{tabular}

\subsection{Indonesia (idr)}

IV: average price of oil and gas

\begin{tabular}{|l|l|l|l|l|}
\hline & $(1)$ & $(2)$ & $(3)$ & $(4)$ \\
\hline & idr-IV 92-95 & $96-99$ & $00-03$ & $04-07$ \\
\hline$\Delta[\operatorname{logRes}+\log E x]$ & 0.263 & $0.869^{*}$ & 0.334 & 0.364 \\
\hline & $(0.421)$ & $(0.491)$ & $(0.467)$ & $(0.329)$ \\
\hline JPY & 0.007 & 0.303 & -0.097 & -0.142 \\
\hline & $(0.123)$ & $(0.189)$ & $(0.329)$ & $(0.166)$ \\
\hline USD & -0.039 & -0.142 & 27.967 & 0.571 \\
\hline & $(1.889)$ & $(0.876)$ & $(51.509)$ & $(1.053)$ \\
\hline KRW & 0.043 & $-0.281^{*}$ & 0.095 & -0.004 \\
\hline & $(0.220)$ & $(0.153)$ & $(0.197)$ & $(0.231)$ \\
\hline SGD & 0.013 & -0.043 & 1.374 & 0.525 \\
\hline & $(0.265)$ & $(1.371)$ & $(1.189)$ & $(0.481)$ \\
\hline AUD & -0.015 & -0.188 & 0.103 & $0.320^{*}$ \\
\hline & $(0.058)$ & $(0.523)$ & $(0.187)$ & $(0.180)$ \\
\hline MYR & -0.036 & 0.306 & -28.750 & -0.295 \\
\hline & $(0.097)$ & $(0.676)$ & $(51.078)$ & $(0.911)$ \\
\hline THB & 0.916 & 0.169 & 0.229 & 0.440 \\
\hline & $(1.823)$ & $(0.305)$ & $(0.414)$ & $(0.381)$ \\
\hline German mark & 0.111 & 0.329 & & \\
\hline & $(0.207)$ & $(0.529)$ & & -0.237 \\
\hline Euro & & & 0.116 & $(0.292)$ \\
\hline & & & $(0.354)$ & -0.006 \\
\hline Constant & $-0.004^{*}$ & $-0.017^{*}$ & -0.003 & $(0.004)$ \\
\hline & $(0.002)$ & $(0.009)$ & $(0.005)$ & 41 \\
\hline Observations & 47 & 36 & 48 & 0.858 \\
\hline R-squared & 0.953 & 0.952 & 0.730 & -0.177 \\
\hline GBP & -0.001 & 0.547 & -0.037 & \\
\hline
\end{tabular}

\footnotetext{
* Statistically significant at .10 level

** Statistically significant at $\mathbf{0 5}$ level $* * *$ Statistically significant at .01 level
} 
Table 4: Change in reserves defined as percent of monetary base, rather than as percent of reserves. OLS

$\Delta$ EMP defined as: $[\operatorname{res}(t)-\operatorname{res}(t-1)] / m b(t-1)+[\operatorname{exr}(t)-\operatorname{exr}(t-1)] / \operatorname{exr}(t-1)$

1. Known peggers: China, Hong Kong, Malaysia

4.1 China

\begin{tabular}{|c|c|c|}
\hline & $(1)$ & $(2)$ \\
\hline & cny $01-04$ & $05-07$ \\
\hline \multirow[t]{2}{*}{ USD } & $0.916^{\star \star \star}$ & $1.029^{* * *}$ \\
\hline & $(0.002)$ & $(0.106)$ \\
\hline \multirow[t]{2}{*}{ JPY } & -0.010 & 0.040 \\
\hline & $(0.016)$ & $(0.031)$ \\
\hline \multirow[t]{2}{*}{ KRW } & 0.000 & 0.058 \\
\hline & $(0.010)$ & $(0.048)$ \\
\hline \multirow[t]{2}{*}{ SGD } & 0.104 & -0.150 \\
\hline & $(0.091)$ & $(0.096)$ \\
\hline \multirow[t]{2}{*}{ MYR } & & 0.027 \\
\hline & & $(0.039)$ \\
\hline \multirow[t]{2}{*}{ RUB } & 0.027 & -0.100 \\
\hline & $(0.033)$ & $(0.137)$ \\
\hline \multirow[t]{2}{*}{ AUD } & 0.001 & 0.020 \\
\hline & $(0.011)$ & $(0.025)$ \\
\hline \multirow[t]{2}{*}{ THB } & -0.054 & 0.037 \\
\hline & $(0.050)$ & $(0.044)$ \\
\hline \multirow[t]{2}{*}{ CAD } & -0.017 & $-0.052^{*}$ \\
\hline & $(0.021)$ & $(0.028)$ \\
\hline \multirow[t]{2}{*}{ EUR } & 0.061 & 0.061 \\
\hline & $(0.056)$ & $(0.077)$ \\
\hline \multirow[t]{2}{*}{ EMP defined with MB } & 0.069 & $0.103^{* *}$ \\
\hline & $(0.063)$ & $(0.039)$ \\
\hline \multirow[t]{2}{*}{ Constant } & 0.001 & 0.000 \\
\hline & $(0.001)$ & $(0.001)$ \\
\hline Observations & 48 & 23 \\
\hline R-squared & 0.989 & 0.996 \\
\hline GBP & 0.000 & 0.030 \\
\hline
\end{tabular}

4.2 Hong Kong

\begin{tabular}{|l|l|l|l|}
\hline & $(1)$ & $(2)$ & $(3)$ \\
\hline & hkd 97-00 & $01-04$ & $05-07$ \\
\hline JPY & 0.000 & -0.002 & -0.009 \\
\hline & $(0.003)$ & $(0.011)$ & $(0.019)$ \\
\hline USD & $0.987^{* * *}$ & -302.382 & $1.015^{* * *}$ \\
\hline & $(0.013)$ & $(329.462)$ & $(0.032)$ \\
\hline KRW & 0.003 & 0.001 & 0.012 \\
\hline & $(0.003)$ & $(0.014)$ & $(0.029)$ \\
\hline SGD & 0.002 & -0.021 & 0.023 \\
\hline & $(0.009)$ & $(0.022)$ & $(0.047)$ \\
\hline AUD & 0.004 & -0.002 & 0.023 \\
\hline & $(0.009)$ & $(0.006)$ & $(0.019)$ \\
\hline
\end{tabular}




\begin{tabular}{|l|l|l|l|}
\hline MYR & -0.005 & 303.372 & -0.017 \\
\hline & $(0.005)$ & $(329.454)$ & $(0.036)$ \\
\hline THB & -0.001 & 0.018 & -0.016 \\
\hline & $(0.004)$ & $(0.018)$ & $(0.030)$ \\
\hline DEM (Deutsche Mark) & -0.002 & & \\
\hline & $(0.007)$ & & \\
\hline EMP defined with MB & 0.000 & $-0.007 *$ & -0.013 \\
\hline & $(0.001)$ & $(0.004)$ & $(0.010)$ \\
\hline EUR & & 0.004 & -0.007 \\
\hline & & $(0.008)$ & $(0.030)$ \\
\hline Constant & -0.000 & -0.000 & -0.000 \\
\hline & $(0.000)$ & $(0.000)$ & $(0.000)$ \\
\hline Observations & 23 & 48 & 30 \\
\hline R-squared & 0.998 & 0.998 & 0.997 \\
\hline GBP & 0.012 & 0.013 & -0.024 \\
\hline
\end{tabular}

\begin{tabular}{|c|c|c|c|c|}
\hline \multicolumn{5}{|c|}{ 4.3 Malaysia } \\
\hline & $(1)$ & $(2)$ & (3) & (4) \\
\hline & myr 92-95 & $96-99$ & $00-03$ & 04-07 \\
\hline \multirow[t]{2}{*}{ JPY } & -0.038 & -0.222 & -0.000 & -0.046 \\
\hline & $(0.194)$ & $(0.168)$ & $(0.000)$ & $(0.060)$ \\
\hline \multirow[t]{2}{*}{ USD } & 0.324 & 0.121 & $1.000 * * *$ & $0.648 * * *$ \\
\hline & $(1.895)$ & $(0.263)$ & $(0.000)$ & $(0.095)$ \\
\hline \multirow[t]{2}{*}{ KRW } & -0.242 & -0.071 & 0.000 & -0.118 \\
\hline & $(0.469)$ & $(0.065)$ & $(0.000)$ & $(0.072)$ \\
\hline \multirow[t]{2}{*}{ SGD } & $0.928^{*}$ & $1.137 * *$ & -0.000 & $0.458 * * *$ \\
\hline & $(0.532)$ & $(0.554)$ & $(0.000)$ & $(0.163)$ \\
\hline \multirow[t]{2}{*}{ AUD } & -0.047 & -0.075 & 0.000 & 0.030 \\
\hline & $(0.096)$ & $(0.199)$ & $(0.000)$ & $(0.049)$ \\
\hline \multirow[t]{2}{*}{ THB } & 0.181 & 0.192 & 0.000 & 0.059 \\
\hline & $(2.016)$ & $(0.241)$ & $(0.000)$ & $(0.068)$ \\
\hline \multirow[t]{2}{*}{ DEM } & -0.059 & -0.091 & & \\
\hline & $(0.167)$ & $(0.216)$ & & \\
\hline \multirow[t]{2}{*}{ EMP defined with MB } & -0.013 & $0.219^{* * *}$ & -0.000 & $0.011 *$ \\
\hline & $(0.016)$ & $(0.067)$ & $(0.000)$ & $(0.007)$ \\
\hline \multirow[t]{2}{*}{ EUR } & & & -0.000 & -0.030 \\
\hline & & & $(0.000)$ & $(0.087)$ \\
\hline \multirow[t]{2}{*}{ Constant } & -0.001 & -0.008 & 0.000 & 0.001 \\
\hline & $(0.003)$ & $(0.005)$ & $(0.000)$ & $(0.001)$ \\
\hline Observations & 48 & 36 & 48 & 40 \\
\hline R-squared & 0.835 & 0.860 & 1.000 & 0.937 \\
\hline GBP & -0.047 & 0.011 & 0.000 & -0.002 \\
\hline
\end{tabular}

\section{Known basket peggers:}

Chile, Kuwait, Latvia, Malta, Norway, Seychelles, Vanuatu, Western Samoa.

\subsection{Chile}

\begin{tabular}{|l|l|l|l|l|l|l|l|}
\hline & $(1)$ & $(2)$ & $(3)$ & $(4)$ & $(5)$ & $(6)$ & $(7)$ \\
\hline & $\operatorname{clp~80-83}$ & $84-87$ & $88-91$ & $92-95$ & $96-99$ & $00-03$ & $04-07$ \\
\hline JPY & 0.013 & 0.566 & -0.006 & $0.225^{* *}$ & $0.089^{* *}$ & 0.103 & -0.068 \\
\hline & $(0.102)$ & $(0.461)$ & $(0.103)$ & $(0.091)$ & $(0.041)$ & $(0.159)$ & $(0.159)$ \\
\hline USD & $0.674^{* *}$ & $1.329^{* * *}$ & $1.040^{* * *}$ & $0.870^{* * *}$ & $0.998^{* * *}$ & $0.619^{* *}$ & $0.804^{* * *}$ \\
\hline & $(0.251)$ & $(0.381)$ & $(0.075)$ & $(0.101)$ & $(0.090)$ & $(0.261)$ & $(0.172)$ \\
\hline DEM & 0.275 & -0.343 & $-0.276^{* *}$ & -0.150 & 0.065 & & \\
\hline & $(0.208)$ & $(0.469)$ & $(0.125)$ & $(0.141)$ & $(0.078)$ & & \\
\hline
\end{tabular}




\begin{tabular}{|l|l|l|l|l|l|l|l|}
\hline $\begin{array}{l}\text { EMP defined } \\
\text { with MB }\end{array}$ & $0.145^{*}$ & 0.081 & -0.014 & $0.053^{*}$ & $0.048^{* * *}$ & $0.106^{*}$ & $0.090^{* * *}$ \\
\hline & $(0.072)$ & $(0.085)$ & $(0.012)$ & $(0.026)$ & $(0.011)$ & $(0.060)$ & $(0.028)$ \\
\hline EUR & & & & & & 0.023 & $0.612^{* *}$ \\
\hline & & & & & & $(0.132)$ & $(0.295)$ \\
\hline Constant & $-0.010^{* * *}$ & $-0.023 * * *$ & $-0.008^{* * *}$ & $-0.006^{* *}$ & $-0.005^{* * *}$ & -0.003 & 0.002 \\
\hline & $(0.003)$ & $(0.008)$ & $(0.002)$ & $(0.003)$ & $(0.002)$ & $(0.004)$ & $(0.003)$ \\
\hline Observations & 46 & 48 & 48 & 48 & 36 & 48 & 41 \\
\hline R-squared & 0.608 & 0.502 & 0.890 & 0.835 & 0.864 & 0.359 & 0.622 \\
\hline GBP & 0.038 & -0.551 & 0.241 & 0.055 & -0.152 & 0.255 & -0.348 \\
\hline
\end{tabular}

4.5 Kuwait

\begin{tabular}{|l|l|l|l|l|l|l|l|}
\hline & $(1)$ & $(2)$ & $(3)$ & $(4)$ & $(5)$ & $(6)$ & $(7)$ \\
\hline & kwd 80-83 & $84-87$ & $88-91$ & $92-95$ & $96-99$ & $00-03$ & $04-07$ \\
\hline JPY & $0.077^{* * *}$ & $0.177^{* * *}$ & $0.118^{* *}$ & $0.067^{* *}$ & $0.049^{* * *}$ & $0.052^{* * *}$ & 0.015 \\
\hline & $(0.014)$ & $(0.052)$ & $(0.052)$ & $(0.030)$ & $(0.006)$ & $(0.012)$ & $(0.015)$ \\
\hline USD & $0.800^{* * *}$ & $0.690^{* * *}$ & $0.671^{* * *}$ & $0.779^{* * *}$ & $0.849^{* * *}$ & $0.845^{* * *}$ & $0.997 * * *$ \\
\hline & $(0.019)$ & $(0.046)$ & $(0.041)$ & $(0.031)$ & $(0.018)$ & $(0.031)$ & $(0.023)$ \\
\hline DEM & $0.048^{* * *}$ & 0.140 & $0.173^{* * *}$ & 0.072 & $0.050^{* *}$ & & \\
\hline & $(0.016)$ & $(0.090)$ & $(0.048)$ & $(0.050)$ & $(0.018)$ & & -0.001 \\
\hline $\begin{array}{l}\text { EMP } \\
\text { Mefined with }\end{array}$ & -0.004 & -0.005 & -0.001 & -0.002 & -0.001 & & -0.000 \\
\hline & & & & & & \\
\hline EUR & $(0.003)$ & $(0.006)$ & $(0.002)$ & $(0.003)$ & $(0.002)$ & $(0.001)$ & $(0.000)$ \\
\hline & & & & & & $0.048^{* * *}$ & -0.036 \\
\hline Constant & -0.000 & $-0.002^{*}$ & $-0.002^{*}$ & -0.001 & 0.000 & $0.016)$ & $(0.028)$ \\
\hline & $(0.001)$ & $(0.001)$ & $(0.001)$ & $(0.001)$ & $(0.000)$ & $(0.000)$ & $(0.000)$ \\
\hline Observations & 46 & 48 & 39 & 48 & 36 & 48 & 41 \\
\hline R-squared & 0.982 & 0.932 & 0.972 & 0.968 & 0.991 & 0.985 & 0.991 \\
\hline GBP & 0.074 & -0.007 & 0.037 & 0.083 & 0.052 & 0.055 & 0.024 \\
\hline
\end{tabular}

\subsection{Latvia}

\begin{tabular}{|c|c|c|c|c|}
\hline & $(1)$ & $(2)$ & (3) & (4) \\
\hline & Ivl 93-96 & $97-00$ & $01-04$ & $05-07$ \\
\hline \multirow[t]{2}{*}{ JPY } & $0.234^{* * *}$ & $0.152^{\star \star \star}$ & 0.056 & -0.003 \\
\hline & $(0.046)$ & $(0.019)$ & $(0.034)$ & $(0.144)$ \\
\hline \multirow[t]{2}{*}{ USD } & $0.439^{* \star *}$ & $0.429^{* * *}$ & 0.048 & -0.005 \\
\hline & $(0.069)$ & $(0.067)$ & $(0.124)$ & $(0.278)$ \\
\hline \multirow[t]{2}{*}{ RUB } & -0.012 & -0.005 & $0.391^{* * *}$ & 0.256 \\
\hline & $(0.024)$ & $(0.007)$ & $(0.118)$ & $(0.490)$ \\
\hline \multirow[t]{2}{*}{ DEM } & $0.268^{* * *}$ & $0.315^{* * *}$ & & \\
\hline & $(0.036)$ & $(0.057)$ & & \\
\hline \multirow[t]{2}{*}{ EMP defined with MB } & $0.081^{* *}$ & 0.025 & 0.009 & 0.002 \\
\hline & $(0.032)$ & $(0.015)$ & $(0.014)$ & $(0.048)$ \\
\hline \multirow[t]{2}{*}{ EUR } & & & $0.332^{\star * \star}$ & 0.550 \\
\hline & & & $(0.055)$ & $(0.345)$ \\
\hline \multirow[t]{2}{*}{ Constant } & 0.000 & -0.001 & -0.002 & -0.000 \\
\hline & $(0.001)$ & $(0.001)$ & $(0.001)$ & $(0.003)$ \\
\hline Observations & 34 & 18 & 48 & 24 \\
\hline R-squared & 0.894 & 0.948 & 0.799 & 0.517 \\
\hline GBP & 0.072 & 0.110 & 0.173 & 0.202 \\
\hline
\end{tabular}

4.7 Malta

\begin{tabular}{|l|l|l|l|l|l|l|l|}
\hline & $(1)$ & $(2)$ & $(3)$ & $(4)$ & $(5)$ & $(6)$ & $(7)$ \\
\hline & $\begin{array}{l}\mathrm{mtl} 80- \\
83\end{array}$ & $84-87$ & $88-91$ & $92-95$ & $96-99$ & $00-03$ & $04-07$ \\
\hline JPY & $0.054^{* * *}$ & $0.090^{\star * *}$ & 0.003 & 0.067 & 0.152 & $0.039^{*}$ & -0.005 \\
\hline
\end{tabular}




\begin{tabular}{|l|l|l|l|l|l|l|l|}
\hline & $(0.020)$ & $(0.033)$ & $(0.029)$ & $(0.077)$ & $(0.147)$ & $(0.020)$ & $(0.032)$ \\
\hline USD & $0.352^{* * *}$ & $0.297^{* * *}$ & $0.303^{* * *}$ & $0.223^{* * *}$ & $0.413^{* *}$ & $0.208^{* * *}$ & 0.049 \\
\hline & $(0.044)$ & $(0.024)$ & $(0.024)$ & $(0.080)$ & $(0.195)$ & $(0.034)$ & $(0.031)$ \\
\hline DEM & $0.326^{* * *}$ & $0.466^{* * *}$ & $0.349^{* * *}$ & $0.440^{* * *}$ & 0.173 & & \\
\hline & $(0.034)$ & $(0.049)$ & $(0.034)$ & $(0.073)$ & $(0.239)$ & & \\
\hline EMP defined with MB & $0.024^{*}$ & 0.004 & 0.051 & 0.169 & $0.491^{* * *}$ & $0.057^{* *}$ & 0.017 \\
\hline & $(0.014)$ & $(0.056)$ & $(0.034)$ & $(0.142)$ & $(0.132)$ & $(0.021)$ & $(0.015)$ \\
\hline EUR & & & & & & $0.505^{* * *}$ & $0.867^{* * *}$ \\
\hline & & & & & & $(0.024)$ & $(0.053)$ \\
\hline Constant & -0.000 & 0.000 & 0.000 & -0.003 & -0.003 & 0.000 & -0.000 \\
\hline & $(0.001)$ & $(0.001)$ & $(0.001)$ & $(0.002)$ & $(0.004)$ & $(0.001)$ & $(0.001)$ \\
\hline Observations & 46 & 48 & 48 & 48 & 36 & 45 & 41 \\
\hline R-squared & 0.919 & 0.957 & 0.934 & 0.563 & 0.691 & 0.933 & 0.892 \\
\hline GBP & 0.267 & 0.147 & 0.344 & 0.269 & 0.262 & 0.248 & 0.089 \\
\hline
\end{tabular}

4.8 Norway

\begin{tabular}{|l|l|l|l|l|l|l|l|}
\hline & $(1)$ & $(2)$ & $(3)$ & $(4)$ & $(5)$ & $(6)$ & $(7)$ \\
\hline & nok 80-83 & $84-87$ & $88-91$ & $92-95$ & $96-99$ & $00-03$ & $04-07$ \\
\hline JPY & $0.124^{*}$ & 0.055 & -0.007 & -0.049 & $-0.099^{*}$ & 0.055 & 0.005 \\
\hline & $(0.063)$ & $(0.077)$ & $(0.054)$ & $(0.047)$ & $(0.051)$ & $(0.074)$ & $(0.304)$ \\
\hline USD & $0.276^{* * *}$ & $0.122^{*}$ & $0.185^{* * *}$ & $0.076^{*}$ & $0.264^{*}$ & 0.008 & 0.048 \\
\hline & $(0.073)$ & $(0.069)$ & $(0.034)$ & $(0.039)$ & $(0.146)$ & $(0.108)$ & $(0.273)$ \\
\hline DEM & $0.451^{* * *}$ & $0.689^{* * *}$ & $0.543^{* * *}$ & $0.795^{* * *}$ & $0.910^{* * *}$ & & \\
\hline & $(0.056)$ & $(0.133)$ & $(0.061)$ & $(0.073)$ & $(0.109)$ & & \\
\hline EMP define with MB & 0.010 & 0.027 & $0.017^{*}$ & 0.012 & 0.015 & -0.009 & -0.010 \\
\hline & $(0.014)$ & $(0.018)$ & $(0.009)$ & $(0.011)$ & $(0.009)$ & $(0.012)$ & $(0.028)$ \\
\hline EUR & & & & & & $0.855^{* * *}$ & $1.469^{* *}$ \\
\hline & & & & & & $(0.114)$ & $(0.542)$ \\
\hline Constant & $-0.005^{* *}$ & $-0.006^{*}$ & 0.000 & -0.002 & -0.001 & -0.000 & 0.005 \\
\hline & $(0.002)$ & $(0.003)$ & $(0.001)$ & $(0.002)$ & $(0.002)$ & $(0.003)$ & $(0.008)$ \\
\hline Observations & 46 & 48 & 48 & 48 & 36 & 48 & 11 \\
\hline R-squared & 0.785 & 0.724 & 0.758 & 0.782 & 0.765 & 0.625 & 0.658 \\
\hline GBP & 0.149 & 0.134 & 0.279 & 0.178 & -0.075 & 0.082 & -0.522 \\
\hline
\end{tabular}

4.9 Seychelles

\begin{tabular}{|l|l|l|l|l|l|l|l|}
\hline & $(1)$ & $(2)$ & $(3)$ & $(4)$ & $(5)$ & $(6)$ & $(7)$ \\
\hline & $\begin{array}{l}\text { scr } 80- \\
83\end{array}$ & $84-87$ & $88-91$ & $92-95$ & $96-99$ & $00-03$ & $04-07$ \\
\hline JPY & -0.064 & $0.188^{* * *}$ & $0.170^{* * *}$ & $0.203^{* * *}$ & 0.047 & $0.319^{* * *}$ & 0.077 \\
\hline & $(0.155)$ & $(0.029)$ & $(0.016)$ & $(0.016)$ & $(0.048)$ & $(0.115)$ & $(0.087)$ \\
\hline USD & $0.359^{* * *}$ & $0.442^{* * *}$ & $0.378^{* * *}$ & $0.394^{* * *}$ & $0.539^{* * *}$ & $0.354^{* * *}$ & $0.926^{* * *}$ \\
\hline & $(0.096)$ & $(0.018)$ & $(0.019)$ & $(0.017)$ & $(0.100)$ & $(0.127)$ & $(0.081)$ \\
\hline DEM & $0.462^{* * *}$ & $0.288^{* * *}$ & $0.299^{* * *}$ & $0.278^{* * *}$ & 0.131 & & \\
\hline & $(0.132)$ & $(0.027)$ & $(0.028)$ & $(0.018)$ & $(0.106)$ & & \\
\hline EMP defined with MB & 0.046 & -0.004 & 0.006 & -0.006 & 0.144 & 0.053 & 0.016 \\
\hline EUR & $(0.046)$ & $(0.005)$ & $(0.007)$ & $(0.005)$ & $(0.104)$ & $(0.042)$ & $(0.015)$ \\
\hline & & & & & & -0.006 & 0.160 \\
\hline Constant & & & & & & $(0.119)$ & $(0.102)$ \\
\hline & 0.005 & 0.000 & -0.000 & 0.000 & -0.003 & -0.001 & $-0.003^{* *}$ \\
\hline Observations & $(0.005)$ & $(0.000)$ & $(0.000)$ & $(0.000)$ & $(0.002)$ & $(0.003)$ & $(0.001)$ \\
\hline R-squared & 46 & 48 & 48 & 48 & 36 & 48 & 42 \\
\hline GBP & 0.556 & 0.985 & 0.985 & 0.992 & 0.621 & 0.414 & 0.836 \\
\hline
\end{tabular}


4.10 Vanuatu

\begin{tabular}{|c|c|c|c|c|c|c|c|}
\hline & (1) & (2) & (3) & (4) & (5) & (6) & (7) \\
\hline & vuv $81-84$ & $85-88$ & $89-92$ & $93-96$ & $97-00$ & $01-04$ & $05-07$ \\
\hline \multirow[t]{2}{*}{ JPY } & 0.111 & 0.418 & 0.055 & $0.145^{\star \star}$ & 0.019 & 0.014 & 0.084 \\
\hline & $(0.079)$ & $(0.314)$ & $(0.190)$ & $(0.066)$ & $(0.028)$ & $(0.034)$ & $(0.061)$ \\
\hline \multirow[t]{2}{*}{ USD } & -0.220 & 0.124 & 0.637 & $0.670^{\star * *}$ & $0.422^{* \star *}$ & -314.737 & 0.128 \\
\hline & $(0.502)$ & $(0.408)$ & $(0.602)$ & $(0.188)$ & $(0.063)$ & $(1,037.297)$ & $(0.112)$ \\
\hline \multirow[t]{2}{*}{ KRW } & 0.454 & 0.348 & -0.359 & 0.035 & 0.015 & -0.030 & 0.027 \\
\hline & $(0.421)$ & $(0.411)$ & $(0.480)$ & $(0.134)$ & $(0.010)$ & $(0.038)$ & $(0.051)$ \\
\hline \multirow[t]{2}{*}{ SGD } & 0.374 & 0.405 & -0.158 & 0.023 & -0.120 & 0.054 & 0.010 \\
\hline & $(0.269)$ & $(0.472)$ & $(0.700)$ & $(0.313)$ & $(0.095)$ & $(0.077)$ & $(0.096)$ \\
\hline \multirow[t]{2}{*}{ AUD } & -0.054 & 0.029 & $0.299^{* *}$ & $0.338^{* * *}$ & $0.308^{* * *}$ & $0.329^{* * *}$ & $0.200^{* *}$ \\
\hline & $(0.109)$ & $(0.088)$ & $(0.127)$ & $(0.090)$ & $(0.061)$ & $(0.055)$ & $(0.075)$ \\
\hline \multirow[t]{2}{*}{ NZD } & -0.010 & -0.011 & $0.468^{* *}$ & 0.076 & 0.104 & $0.185^{* * *}$ & $0.156^{\star \star \star}$ \\
\hline & $(0.028)$ & $(0.127)$ & $(0.214)$ & $(0.096)$ & $(0.064)$ & $(0.038)$ & $(0.036)$ \\
\hline \multirow[t]{2}{*}{ MYR } & -0.049 & -0.577 & -0.163 & $-0.368^{* * *}$ & 0.036 & 315.063 & 0.187 \\
\hline & $(0.267)$ & $(0.577)$ & $(0.201)$ & $(0.133)$ & $(0.035)$ & $(1,037.284)$ & $(0.156)$ \\
\hline \multirow[t]{2}{*}{ DEM } & $0.286^{* * *}$ & 0.056 & $0.424^{* *}$ & 0.060 & 0.084 & & \\
\hline & $(0.081)$ & $(0.273)$ & $(0.160)$ & $(0.069)$ & $(0.054)$ & & \\
\hline \multirow{2}{*}{$\begin{array}{l}\text { EMP defined } \\
\text { with MB }\end{array}$} & 0.002 & -0.005 & -0.028 & 0.009 & -0.000 & $0.029^{* *}$ & 0.030 \\
\hline & $(0.007)$ & $(0.017)$ & $(0.027)$ & $(0.016)$ & $(0.007)$ & $(0.012)$ & $(0.018)$ \\
\hline \multirow[t]{2}{*}{ EUR } & & & & & & 0.018 & 0.051 \\
\hline & & & & & & $(0.047)$ & $(0.076)$ \\
\hline \multirow[t]{2}{*}{ Constant } & 0.001 & -0.013 & -0.001 & -0.000 & -0.002 & 0.001 & -0.001 \\
\hline & $(0.002)$ & $(0.008)$ & $(0.004)$ & $(0.002)$ & $(0.001)$ & $(0.001)$ & $(0.001)$ \\
\hline Observations & 46 & 48 & 48 & 48 & 24 & 48 & 25 \\
\hline R-squared & 0.807 & 0.460 & 0.820 & 0.909 & 0.968 & 0.941 & 0.961 \\
\hline GBP & 0.108 & 0.209 & -0.204 & 0.021 & 0.131 & 0.105 & 0.157 \\
\hline
\end{tabular}

\subsection{Western Samoa}

\begin{tabular}{|c|c|c|c|c|c|c|c|}
\hline wst & $(1)$ & (2) & (3) & (4) & $(5)$ & (6) & $(7)$ \\
\hline & $80-83$ & $84-87$ & $88-91$ & $92-95$ & $96-99$ & $00-03$ & 04-07 \\
\hline \multirow[t]{2}{*}{ JPY } & 0.061 & $0.194 *$ & $0.238 * * *$ & $0.068^{*}$ & $0.131 * *$ & 0.004 & 0.001 \\
\hline & $(0.052)$ & $(0.102)$ & $(0.087)$ & $(0.036)$ & $(0.057)$ & $(0.032)$ & $(0.052)$ \\
\hline \multirow[t]{2}{*}{ USD } & 0.357 & -0.291 & $1.022 *$ & $0.503 * * *$ & $0.600 * * *$ & $3,517.899 * * *$ & $0.492 * * *$ \\
\hline & $(0.313)$ & $(0.369)$ & $(0.516)$ & $(0.177)$ & $(0.148)$ & $(903.940)$ & $(0.139)$ \\
\hline \multirow[t]{2}{*}{ KRW } & -0.275 & $0.625^{*}$ & -0.378 & 0.098 & -0.010 & -0.035 & -0.003 \\
\hline & $(0.296)$ & $(0.322)$ & $(0.253)$ & $(0.161)$ & $(0.023)$ & $(0.037)$ & $(0.069)$ \\
\hline \multirow[t]{2}{*}{ SGD } & -0.058 & 0.041 & -0.096 & -0.204 & -0.209 & 0.073 & 0.039 \\
\hline & $(0.189)$ & $(0.148)$ & $(0.174)$ & $(0.130)$ & $(0.153)$ & $(0.122)$ & $(0.147)$ \\
\hline \multirow[t]{2}{*}{ AUD } & 0.337 & -0.054 & $0.095^{*}$ & 0.049 & -0.003 & $0.316^{* * *}$ & $0.195 * * *$ \\
\hline & $(0.525)$ & $(0.081)$ & $(0.049)$ & $(0.047)$ & $(0.111)$ & $(0.038)$ & $(0.054)$ \\
\hline \multirow[t]{2}{*}{ NZD } & 0.545 & $0.491 * * *$ & $0.481 * * *$ & $0.420 * * *$ & $0.504 * * *$ & $0.181 * * *$ & $0.275 * * *$ \\
\hline & $(0.651)$ & $(0.094)$ & $(0.102)$ & $(0.062)$ & $(0.132)$ & $(0.043)$ & $(0.052)$ \\
\hline \multirow[t]{2}{*}{ MYR } & 0.226 & -0.020 & -0.485 & 0.018 & 0.041 & $-3,517.487 * * *$ & -0.063 \\
\hline & $(0.258)$ & $(0.192)$ & $(0.460)$ & $(0.040)$ & $(0.064)$ & $(903.980)$ & $(0.165)$ \\
\hline \multirow[t]{2}{*}{ DEM } & -0.073 & -0.075 & -0.050 & -0.033 & 0.035 & & \\
\hline & $(0.093)$ & $(0.128)$ & $(0.165)$ & $(0.049)$ & $(0.075)$ & & \\
\hline \multirow[t]{2}{*}{ EMP defined with MB } & 0.004 & 0.020 & 0.042 & 0.012 & 0.010 & 0.001 & 0.004 \\
\hline & $(0.004)$ & $(0.014)$ & $(0.030)$ & $(0.010)$ & $(0.022)$ & $(0.004)$ & $(0.004)$ \\
\hline \multirow[t]{2}{*}{ EUR } & & & & & & $0.106^{* * *}$ & 0.087 \\
\hline & & & & & & $(0.029)$ & $(0.070)$ \\
\hline \multirow[t]{2}{*}{ Constant } & -0.010 & $-0.008 * *$ & -0.003 & $-0.001 *$ & -0.002 & -0.000 & 0.000 \\
\hline & $(0.006)$ & $(0.003)$ & $(0.002)$ & $(0.001)$ & $(0.002)$ & $(0.001)$ & $(0.001)$ \\
\hline Observations & 40 & 48 & 48 & 48 & 36 & 48 & 41 \\
\hline R-squared & 0.736 & 0.869 & 0.801 & 0.978 & 0.854 & 0.963 & 0.928 \\
\hline GBP & -0.119 & 0.089 & 0.174 & 0.079 & -0.089 & -0.056 & -0.024 \\
\hline
\end{tabular}




\subsection{PNG}

\begin{tabular}{|c|c|c|c|c|}
\hline & (1) & (2) & (3) & (4) \\
\hline & png 92-95 & $96-99$ & $00-03$ & $04-07$ \\
\hline \multirow[t]{2}{*}{ JPY } & 0.199 & $0.522 * *$ & 0.443 & 0.005 \\
\hline & $(0.252)$ & $(0.201)$ & $(0.370)$ & $(0.048)$ \\
\hline \multirow[t]{2}{*}{ USD } & 1.692 & $1.121 * * *$ & $13,625.661$ & $1.073 * * *$ \\
\hline & $(2.127)$ & $(0.376)$ & $(10,523.706)$ & $(0.095)$ \\
\hline \multirow[t]{2}{*}{ KRW } & $-1.327 * *$ & -0.050 & -0.023 & 0.013 \\
\hline & $(0.533)$ & $(0.100)$ & $(0.277)$ & $(0.061)$ \\
\hline \multirow[t]{2}{*}{ SGD } & -0.349 & -0.774 & -0.222 & 0.085 \\
\hline & $(0.657)$ & $(0.674)$ & $(0.742)$ & $(0.143)$ \\
\hline \multirow[t]{2}{*}{ AUD } & $0.285^{* *}$ & 0.132 & 0.197 & 0.012 \\
\hline & $(0.131)$ & $(0.312)$ & $(0.244)$ & $(0.053)$ \\
\hline \multirow[t]{2}{*}{ MYR } & -0.045 & 0.368 & $-13,624.594$ & $-0.190 *$ \\
\hline & $(0.200)$ & $(0.240)$ & $(10,523.750)$ & $(0.095)$ \\
\hline \multirow[t]{2}{*}{ THB } & 0.563 & -0.030 & -0.232 & -0.006 \\
\hline & $(2.394)$ & $(0.095)$ & $(0.523)$ & $(0.062)$ \\
\hline \multirow[t]{2}{*}{ DEM } & 0.135 & -0.202 & & \\
\hline & $(0.224)$ & $(0.290)$ & & \\
\hline \multirow[t]{2}{*}{ EMP defined with MB } & 0.025 & $0.062 * *$ & $0.129 * * *$ & 0.003 \\
\hline & $(0.020)$ & $(0.026)$ & $(0.032)$ & $(0.003)$ \\
\hline \multirow[t]{2}{*}{ EUR } & & & 0.378 & -0.018 \\
\hline & & & $(0.358)$ & $(0.070)$ \\
\hline \multirow[t]{2}{*}{ Constant } & $-0.008 *$ & -0.010 & -0.009 & $0.002 * *$ \\
\hline & $(0.004)$ & $(0.006)$ & $(0.007)$ & $(0.001)$ \\
\hline Observations & 48 & 36 & 48 & 41 \\
\hline R-squared & 0.732 & 0.519 & 0.553 & 0.965 \\
\hline GBP & -0.154 & -0.086 & -0.608 & 0.025 \\
\hline
\end{tabular}

4.13 Fiji

\begin{tabular}{|c|c|c|c|c|c|c|c|}
\hline & (1) & (2) & (3) & (4) & (5) & (6) & (7) \\
\hline & fiji $80-83$ & $84-87$ & $88-91$ & $92-95$ & $96-99$ & $00-03$ & $04-07$ \\
\hline \multirow[t]{2}{*}{ JPY } & $0.157 * * *$ & 0.129 & -0.096 & -0.192 & 0.024 & 0.082 & 0.008 \\
\hline & $(0.030)$ & $(0.164)$ & $(0.080)$ & $(0.138)$ & $(0.137)$ & $(0.055)$ & $(0.053)$ \\
\hline \multirow[t]{2}{*}{ USD } & $0.363 * * *$ & $1.510 * *$ & $-1.661 * * *$ & $-2.417 * *$ & $0.365^{* *}$ & 332.309 & 0.313 \\
\hline & $(0.129)$ & $(0.706)$ & $(0.504)$ & $(1.084)$ & $(0.175)$ & $(1,233.864)$ & $(0.202)$ \\
\hline \multirow[t]{2}{*}{ KRW } & -0.146 & -1.154 & 0.052 & $0.794 * * *$ & -0.054 & 0.048 & 0.137 \\
\hline & $(0.103)$ & $(0.706)$ & $(0.087)$ & $(0.284)$ & $(0.063)$ & $(0.046)$ & $(0.095)$ \\
\hline \multirow[t]{2}{*}{ SGD } & -0.028 & -0.363 & 0.074 & 0.114 & 0.046 & 0.064 & -0.149 \\
\hline & $(0.093)$ & $(0.305)$ & $(0.122)$ & $(0.199)$ & $(0.220)$ & $(0.094)$ & $(0.203)$ \\
\hline \multirow[t]{2}{*}{ AUD } & $0.267 * * *$ & $0.399 * *$ & $0.234 * * *$ & $0.210^{* * *}$ & -0.110 & $0.449 * * *$ & $0.440 * * *$ \\
\hline & $(0.081)$ & $(0.190)$ & $(0.043)$ & $(0.055)$ & $(0.377)$ & $(0.053)$ & $(0.074)$ \\
\hline \multirow[t]{2}{*}{ MYR } & $0.178^{*}$ & 0.381 & -0.070 & -0.020 & 0.334 & -332.083 & 0.063 \\
\hline & $(0.100)$ & $(0.379)$ & $(0.174)$ & $(0.071)$ & $(0.298)$ & $(1,233.860)$ & $(0.260)$ \\
\hline \multirow[t]{2}{*}{ THB } & 0.023 & -0.043 & $2.535 * * *$ & $2.557 * *$ & -0.022 & -0.080 & -0.084 \\
\hline & $(0.022)$ & $(0.058)$ & $(0.621)$ & $(1.136)$ & $(0.119)$ & $(0.073)$ & $(0.080)$ \\
\hline \multirow[t]{2}{*}{ DEM } & -0.006 & -0.049 & $-0.113^{*}$ & $-0.204 * *$ & 0.149 & & \\
\hline & $(0.030)$ & $(0.160)$ & $(0.057)$ & $(0.084)$ & $(0.169)$ & & \\
\hline \multirow[t]{2}{*}{ EMP defined with MB } & 0.004 & $0.135 * * *$ & -0.008 & $-0.017 *$ & 0.084 & 0.013 & 0.012 \\
\hline & $(0.004)$ & $(0.049)$ & $(0.008)$ & $(0.010)$ & $(0.066)$ & $(0.013)$ & $(0.018)$ \\
\hline \multirow[t]{2}{*}{ EUR } & & & & & & $0.181 * * *$ & 0.101 \\
\hline & & & & & & $(0.042)$ & $(0.104)$ \\
\hline \multirow[t]{2}{*}{ Constant } & $-0.003 *$ & -0.004 & -0.000 & 0.002 & -0.007 & 0.001 & -0.001 \\
\hline & $(0.001)$ & $(0.004)$ & $(0.001)$ & $(0.001)$ & $(0.006)$ & $(0.001)$ & $(0.001)$ \\
\hline Observations & 46 & 48 & 48 & 48 & 36 & 48 & 34 \\
\hline R-squared & 0.954 & 0.677 & 0.965 & 0.967 & 0.392 & 0.945 & 0.885 \\
\hline GBP & 0.193 & 0.191 & 0.046 & 0.159 & 0.268 & 0.029 & 0.171 \\
\hline
\end{tabular}




\section{Known floaters:}

\begin{tabular}{|l|l|l|l|l|}
\hline & $(1)$ & $(2)$ & $(3)$ & $(4)$ \\
\hline & aud 92-95 & $96-99$ & $00-03$ & $04-07$ \\
\hline JPY & 0.018 & 0.208 & $0.251^{* *}$ & 0.165 \\
\hline & $(0.095)$ & $(0.123)$ & $(0.103)$ & $(0.151)$ \\
\hline USD & $0.996^{\star * *}$ & $0.647^{\star * *}$ & 0.270 & 0.176 \\
\hline & $(0.066)$ & $(0.227)$ & $(0.202)$ & $(0.144)$ \\
\hline DEM & -0.148 & -0.112 & & \\
\hline & $(0.133)$ & $(0.199)$ & & \\
\hline EMP defined with MB & $0.301^{* * *}$ & 0.175 & $0.178^{\star * *}$ & 0.032 \\
\hline & $(0.050)$ & $(0.128)$ & $(0.044)$ & $(0.028)$ \\
\hline EUR & & & $0.543^{\star \star *}$ & 0.101 \\
\hline & & & $(0.125)$ & $(0.243)$ \\
\hline Constant & 0.003 & -0.006 & -0.001 & 0.001 \\
\hline & $(0.002)$ & $(0.005)$ & $(0.003)$ & $(0.003)$ \\
\hline Observations & 48 & 36 & 48 & 42 \\
\hline R-squared & 0.854 & 0.384 & 0.540 & 0.164 \\
\hline GBP & 0.134 & 0.257 & -0.064 & 0.559 \\
\hline
\end{tabular}

\subsection{Canada}

\begin{tabular}{|l|l|l|l|l|l|}
\hline & $(1)$ & $(2)$ & $(3)$ & $(4)$ & $(5)$ \\
\hline & cad 90-93 & $94-97$ & $98-01$ & $02-05$ & $06-07$ \\
\hline JPY & 0.060 & 0.018 & 0.035 & $0.321^{* * *}$ & -0.149 \\
\hline & $(0.060)$ & $(0.079)$ & $(0.078)$ & $(0.094)$ & $(0.274)$ \\
\hline USD & $0.870^{* * *}$ & $0.952^{* * *}$ & 0.301 & $0.468^{* * *}$ & $0.538^{*}$ \\
\hline DEM & $(0.058)$ & $(0.091)$ & $(0.321)$ & $(0.117)$ & $(0.269)$ \\
\hline & 0.016 & 0.026 & 0.119 & & \\
\hline EMP defined with MB & $(0.067)$ & $(0.076)$ & $(0.309)$ & & \\
\hline & $0.149^{* * *}$ & $0.084^{* * *}$ & $0.126^{* *}$ & $0.355^{* * *}$ & $0.434^{* *}$ \\
\hline EUR & $(0.024)$ & $(0.028)$ & $(0.035)$ & $(0.099)$ & $(0.140)$ \\
\hline & & & & $0.349^{*}$ & 0.179 \\
\hline Constant & & & & $(0.179)$ & $(0.484)$ \\
\hline & $-0.002^{*}$ & -0.002 & -0.009 & $0.004^{*}$ & -0.005 \\
\hline Observations & $(0.001)$ & $(0.002)$ & $(0.006)$ & $(0.002)$ & $(0.004)$ \\
\hline R-squared & 48 & 48 & 8 & 48 & 14 \\
\hline GBP & 0.957 & 0.796 & 0.777 & 0.712 & 0.712 \\
\hline
\end{tabular}

\footnotetext{
* Statistically significant at .10 level ** Statistically significant at $\mathbf{0 5}$ level $* * *$ Statistically significant at .01 level
} 
Table 5: Change in reserves defined as \% of monetary base. IV

$\Delta$ EMP defined as: $[\operatorname{res}(t)-\operatorname{res}(t-1)] / m b(t-1)+[\operatorname{exr}(t)-\operatorname{exr}(t-1)] / \operatorname{exr}(t-1)$

Estimating the De Facto Exchange Rate Regime with commodity prices as instrumental variables for the change in EMP in the case of commodity exporters

$(01 / 1980-06 / 2007) \quad$ numeraire currency $=$ SDR

\subsection{Malaysia (myr)}

IV: average of prices of semiconductors and tin

\begin{tabular}{|c|c|c|c|c|}
\hline & (1) & (2) & (3) & (4) \\
\hline & myr 92-95 & $96-99$ & $00-03$ & $04-07$ \\
\hline \multirow[t]{2}{*}[\Delta\operatorname{Res}/\mathrm{MB}+\Delta\operatorname{log}\mathrm{Ex}]{} & 0.065 & -0.369 & -0.000 & 0.063 \\
\hline & $(0.047)$ & $(1.656)$ & $(0.000)$ & $(0.045)$ \\
\hline \multirow[t]{2}{*}{ JPY } & -0.194 & -0.066 & -0.000 & -0.074 \\
\hline & $(0.249)$ & $(0.485)$ & $(0.000)$ & $(0.092)$ \\
\hline \multirow[t]{2}{*}{ USD } & -1.018 & -0.401 & $1.000 * * *$ & $0.512 * *$ \\
\hline & $(2.964)$ & $(1.595)$ & $(0.000)$ & $(0.187)$ \\
\hline \multirow[t]{2}{*}{ KRW } & 0.087 & -0.136 & 0.000 & -0.099 \\
\hline & $(0.443)$ & $(0.187)$ & $(0.000)$ & $(0.119)$ \\
\hline \multirow[t]{2}{*}{ SGD } & $0.986^{* *}$ & 1.278 & -0.000 & $0.576^{* * *}$ \\
\hline & $(0.484)$ & $(0.884)$ & $(0.000)$ & $(0.243)$ \\
\hline \multirow[t]{2}{*}{ AUD } & -0.190 & 0.075 & 0.000 & -0.044 \\
\hline & $(0.211)$ & $(0.634)$ & $(0.000)$ & $(0.105)$ \\
\hline \multirow[t]{2}{*}{ THB } & 1.447 & 0.736 & 0.000 & 0.047 \\
\hline & $(3.196)$ & $(1.442)$ & $(0.000)$ & $(0.116)$ \\
\hline \multirow[t]{2}{*}{ Deutsche Mark } & -0.103 & -0.289 & & \\
\hline & $(0.253)$ & $(0.687)$ & & \\
\hline \multirow[t]{2}{*}{ EUR } & & & -0.000 & 0.004 \\
\hline & & & $(0.000)$ & $(0.150)$ \\
\hline \multirow[t]{2}{*}{ Constant } & -0.002 & 0.001 & 0.000 & -0.004 \\
\hline & $(0.004)$ & $(0.026)$ & $(0.000)$ & $(0.005)$ \\
\hline Observations & 48 & 36 & 48 & 40 \\
\hline R-squared & 0.693 & 0.619 & 1.000 & 0.863 \\
\hline GBP & -0.015 & -0.196 & 0.000 & 0.077 \\
\hline
\end{tabular}

\subsection{Chile (clp)}

Instrumental Variable : Price of copper

\begin{tabular}{|l|l|l|l|l|l|l|l|}
\hline & $(1)$ & $(2)$ & $(3)$ & $(4)$ & $(5)$ & $(6)$ & $(7)$ \\
\hline & $\operatorname{clp~80-83}$ & $84-87$ & $88-91$ & $92-95$ & $96-99$ & $00-03$ & $04-07$ \\
\hline $\begin{array}{l}{[\Delta \text { Res/MB }+} \\
\Delta \operatorname{logEx}]\end{array}$ & $0.319^{* * *}$ & 7.457 & -0.133 & 0.083 & $0.085^{* *}$ & 0.093 & -0.467 \\
\hline & $(0.112)$ & $(133.668)$ & $(0.405)$ & $(0.057)$ & $(0.031)$ & $(0.299)$ & $(1.403)$ \\
\hline JPY & 0.009 & 15.759 & -0.275 & $0.212^{* *}$ & $0.097 * *$ & 0.098 & -0.425 \\
\hline
\end{tabular}




\begin{tabular}{|l|l|l|l|l|l|l|l|}
\hline & $(0.190)$ & $(277.627)$ & $(0.974)$ & $(0.081)$ & $(0.042)$ & $(0.213)$ & $(0.853)$ \\
\hline USD & $0.448^{*}$ & -24.467 & 1.398 & $0.816^{* * *}$ & $0.969^{* * *}$ & 0.636 & 1.622 \\
\hline & $(0.234)$ & $(465.661)$ & $(1.243)$ & $(0.118)$ & $(0.108)$ & $(0.524)$ & $(1.978)$ \\
\hline $\begin{array}{l}\text { Deutsche } \\
\text { Mark }\end{array}$ & $0.540^{* *}$ & 6.057 & -0.471 & -0.117 & 0.091 & & \\
\hline & $(0.208)$ & $(112.040)$ & $(0.695)$ & $(0.129)$ & $(0.078)$ & & \\
\hline EUR & & & & & & 0.014 & -0.118 \\
\hline & & & & & & $(0.241)$ & $(2.104)$ \\
\hline Constant & $-0.007^{*}$ & -0.113 & 0.002 & $-0.008^{* *}$ & $-0.006^{* *}$ & -0.003 & 0.006 \\
\hline & $(0.004)$ & $(1.673)$ & $(0.035)$ & $(0.003)$ & $(0.002)$ & $(0.004)$ & $(0.013)$ \\
\hline Observations & 46 & 48 & 48 & 48 & 36 & 48 & 41 \\
\hline R-squared & 0.428 & & 0.500 & 0.824 & 0.827 & 0.358 & \\
\hline GBP & 0.003 & 3.651 & 0.348 & 0.088 & -0.157 & 0.252 & -0.078 \\
\hline
\end{tabular}

\subsection{Kuwait (kwd)}

\section{IV: Price of oil}

\begin{tabular}{|c|c|c|c|c|c|c|c|}
\hline & (1) & (2) & (3) & (4) & (5) & (6) & (7) \\
\hline & kwd 80-83 & $84-87$ & $88-91$ & $92-95$ & $96-99$ & $00-03$ & $04-07$ \\
\hline \multirow{2}{*}{$\begin{array}{l}{[\Delta \mathrm{Res} / \mathrm{MB}+} \\
\Delta \log \mathrm{Ex}]\end{array}$} & -0.003 & 0.127 & 0.017 & -0.019 & -0.031 & 0.072 & 0.005 \\
\hline & $(0.011)$ & $(0.325)$ & $(0.019)$ & $(0.024)$ & $(0.106)$ & $(0.705)$ & $(0.007)$ \\
\hline \multirow[t]{2}{*}{ JPY } & $0.077 * * *$ & 0.371 & 0.105 & 0.048 & 0.027 & 0.121 & 0.021 \\
\hline & $(0.014)$ & $(0.514)$ & $(0.074)$ & $(0.032)$ & $(0.078)$ & $(0.669)$ & $(0.021)$ \\
\hline \multirow[t]{2}{*}{ USD } & $0.800 * * *$ & 0.322 & $0.649^{* * *}$ & $0.816^{* * *}$ & $0.893 * * *$ & 0.542 & $0.993^{* * *}$ \\
\hline & $(0.026)$ & $(0.906)$ & $(0.044)$ & $(0.065)$ & $(0.162)$ & $(2.952)$ & $(0.030)$ \\
\hline \multirow{2}{*}{$\begin{array}{l}\text { Deutsche } \\
\text { Mark }\end{array}$} & $0.049 * *$ & 0.308 & $0.147 * *$ & 0.068 & 0.032 & & \\
\hline & $(0.021)$ & $(0.450)$ & $(0.072)$ & $(0.066)$ & $(0.084)$ & & \\
\hline \multirow[t]{2}{*}{ EUR } & & & & & & 0.129 & -0.064 \\
\hline & & & & & & $(0.831)$ & $(0.049)$ \\
\hline \multirow[t]{2}{*}{ Constant } & -0.000 & -0.002 & -0.001 & -0.001 & 0.000 & -0.002 & -0.000 \\
\hline & $(0.001)$ & $(0.005)$ & $(0.001)$ & $(0.001)$ & $(0.001)$ & $(0.027)$ & $(0.001)$ \\
\hline Observations & 46 & 48 & 39 & 48 & 36 & 48 & 41 \\
\hline R-squared & 0.982 & 0.261 & 0.948 & 0.945 & 0.941 & 0.276 & 0.981 \\
\hline GBP & 0.074 & -0.001 & 0.099 & 0.069 & 0.048 & 0.208 & 0.050 \\
\hline
\end{tabular}

\section{IV: oil price}

\subsection{Norway (nok)}

\begin{tabular}{|c|c|c|c|c|c|c|c|}
\hline & (1) & (2) & (3) & (4) & (5) & (6) & (7) \\
\hline & nok $80-83$ & $84-87$ & $88-91$ & $92-95$ & $96-99$ & $00-03$ & 04-07 \\
\hline \multirow{2}{*}{$\begin{array}{l}{[\Delta \mathrm{Res} / \mathrm{MB}+} \\
\Delta \log \mathrm{Ex}]\end{array}$} & -0.043 & 0.056 & 0.026 & -0.060 & 0.095 & -0.800 & -0.008 \\
\hline & $(0.258)$ & $(0.039)$ & $(0.037)$ & $(0.105)$ & $(0.071)$ & $(5.183)$ & $(0.078)$ \\
\hline \multirow[t]{2}{*}{ JPY } & 0.100 & 0.054 & -0.004 & -0.082 & -0.020 & -0.990 & 0.008 \\
\hline & $(0.149)$ & $(0.085)$ & $(0.055)$ & $(0.072)$ & $(0.087)$ & $(6.966)$ & $(0.369)$ \\
\hline \multirow[t]{2}{*}{ USD } & 0.227 & $0.130^{*}$ & $0.186^{* * *}$ & 0.025 & 0.334 & -0.129 & 0.047 \\
\hline & $(0.261)$ & $(0.076)$ & $(0.034)$ & $(0.143)$ & $(0.241)$ & $(1.269)$ & $(0.246)$ \\
\hline \multirow{2}{*}{$\begin{array}{l}\text { Deutsche } \\
\text { Mark }\end{array}$} & $0.420 * * *$ & $0.721 * * *$ & $0.545^{*} * *$ & $0.795^{* * *}$ & $0.842 * * *$ & & \\
\hline & $(0.144)$ & $(0.132)$ & $(0.063)$ & $(0.114)$ & $(0.171)$ & & \\
\hline \multirow[t]{2}{*}{ EUR } & & & & & & 2.929 & $1.472 * *$ \\
\hline & & & & & & $(13.311)$ & $(0.499)$ \\
\hline Constant & -0.003 & $-0.006^{*}$ & 0.000 & 0.001 & 0.000 & 0.009 & 0.005 \\
\hline
\end{tabular}




\begin{tabular}{|l|l|l|l|l|l|l|l|}
\hline & $(0.008)$ & $(0.003)$ & $(0.001)$ & $(0.002)$ & $(0.005)$ & $(0.059)$ & $(0.007)$ \\
\hline Observations & 46 & 48 & 48 & 48 & 36 & 48 & 11 \\
\hline R-squared & 0.732 & 0.688 & 0.754 & 0.399 & 0.103 & & 0.658 \\
\hline GBP & 0.252 & 0.095 & 0.274 & 0.263 & -0.157 & -0.811 & -0.527 \\
\hline
\end{tabular}

5.9 Papua New Guinea kina (png)

IV: average price of gold, copper, oil, gas and timber

\begin{tabular}{|c|c|c|c|c|}
\hline & (1) & (2) & (3) & (4) \\
\hline & png 92-95 & $96-99$ & $00-03$ & $04-07$ \\
\hline \multirow[t]{2}{*}[\Delta\operatorname{Res}/\mathrm{MB}+\Delta\operatorname{log}\mathrm{Ex}]{} & -0.001 & 0.082 & -0.114 & -0.012 \\
\hline & $(0.037)$ & $(0.109)$ & $(0.720)$ & $(0.009)$ \\
\hline \multirow[t]{2}{*}{ JPY } & 0.194 & $0.546^{* *}$ & 1.044 & 0.006 \\
\hline & $(0.302)$ & $(0.226)$ & $(1.954)$ & $(0.054)$ \\
\hline \multirow[t]{2}{*}{ USD } & 2.029 & $1.149^{* * *}$ & 1.849 & $1.203^{* * *}$ \\
\hline & $(2.427)$ & $(0.310)$ & $(2.211)$ & $(0.125)$ \\
\hline \multirow[t]{2}{*}{ KRW } & $-1.262 * *$ & -0.063 & -0.748 & -0.032 \\
\hline & $(0.522)$ & $(0.119)$ & $(1.835)$ & $(0.099)$ \\
\hline \multirow[t]{2}{*}{ SGD } & -0.458 & -0.839 & -0.947 & 0.070 \\
\hline & $(0.640)$ & $(0.602)$ & $(3.008)$ & $(0.213)$ \\
\hline \multirow[t]{2}{*}{ AUD } & $0.311 * *$ & 0.125 & 0.512 & -0.032 \\
\hline & $(0.142)$ & $(0.312)$ & $(1.125)$ & $(0.057)$ \\
\hline \multirow[t]{2}{*}{ MYR } & -0.003 & 0.361 & 0.000 & $-0.333 * *$ \\
\hline & $(0.220)$ & $(0.262)$ & $(0.000)$ & $(0.152)$ \\
\hline \multirow[t]{2}{*}{ THB } & 0.191 & -0.005 & -0.377 & 0.018 \\
\hline & $(2.727)$ & $(0.121)$ & $(0.845)$ & $(0.076)$ \\
\hline \multirow[t]{2}{*}{ Deutsche Mark } & 0.135 & -0.193 & & \\
\hline & $(0.289)$ & $(0.288)$ & & \\
\hline \multirow[t]{2}{*}{ EUR } & & & 0.578 & -0.004 \\
\hline & & & $(0.604)$ & $(0.091)$ \\
\hline \multirow[t]{2}{*}{ Constant } & $-0.008 * *$ & -0.009 & -0.005 & $0.004 * * *$ \\
\hline & $(0.004)$ & $(0.006)$ & $(0.016)$ & $(0.001)$ \\
\hline Observations & 47 & 36 & 48 & 41 \\
\hline R-squared & 0.715 & 0.511 & 0.038 & 0.945 \\
\hline GBP & -0.137 & -0.081 & -0.912 & 0.104 \\
\hline
\end{tabular}

\section{IV: Price of oil}

\subsection{Russia (rub)}

\begin{tabular}{|l|l|l|}
\hline & $(1)$ & $(2)$ \\
\hline & rub 00-03 & $04-07$ \\
\hline$[\Delta$ Res/MB $+\Delta \log E x]$ & $0.001^{*}$ & -0.000 \\
\hline JPY & $(0.000)$ & $(0.000)$ \\
\hline & 0.228 & 0.117 \\
\hline USD & $(0.189)$ & $(0.070)$ \\
\hline & $0.640^{*}$ & $0.551^{* * *}$ \\
\hline EUR & $(0.332)$ & $(0.112)$ \\
\hline & $-0.658^{*}$ & 0.126 \\
\hline Constant & $(0.348)$ & $(0.192)$ \\
\hline & -0.015 & 0.004 \\
\hline Observations & $(0.009)$ & $(0.008)$ \\
\hline R-squared & 24 & 41 \\
\hline GBP & 0.540 & 0.789 \\
\hline
\end{tabular}


IV: rice

\subsection{Thailand (thb)}

\begin{tabular}{|c|c|c|c|c|c|c|c|}
\hline & (1) & (2) & (3) & (4) & (5) & (6) & (7) \\
\hline & thb $80-83$ & $84-87$ & $88-91$ & $92-95$ & $96-99$ & $00-03$ & 04-07 \\
\hline \multirow{2}{*}{$\begin{array}{l}{[\Delta \mathrm{Res} / \mathrm{MB}+} \\
\Delta \operatorname{logEx}]\end{array}$} & 0.006 & 0.001 & 0.000 & -0.000 & 0.000 & 0.000 & $0.000^{*}$ \\
\hline & $(0.046)$ & $(0.003)$ & $(0.000)$ & $(0.005)$ & $(0.000)$ & $(0.000)$ & $(0.000)$ \\
\hline \multirow[t]{2}{*}{ JPY } & -1.543 & -0.190 & 0.152 & -0.094 & -0.071 & 0.103 & -0.045 \\
\hline & $(13.996)$ & $(0.788)$ & $(0.108)$ & $(2.512)$ & $(0.260)$ & $(0.177)$ & $(0.154)$ \\
\hline \multirow[t]{2}{*}{ USD } & 4.892 & 2.033 & $0.760 * * *$ & 1.083 & -0.834 & -96.995 & 0.269 \\
\hline & $(31.577)$ & $(4.331)$ & $(0.076)$ & $(2.581)$ & $(0.601)$ & $(88.172)$ & $(0.554)$ \\
\hline \multirow[t]{2}{*}{ KRW } & 3.726 & -0.632 & 0.013 & -0.257 & 0.139 & 0.044 & 0.203 \\
\hline & (33.609) & $(2.211)$ & $(0.035)$ & $(2.087)$ & $(0.118)$ & $(0.160)$ & $(0.226)$ \\
\hline \multirow[t]{2}{*}{ SGD } & 4.372 & 0.107 & -0.062 & 0.677 & 0.819 & 0.198 & 0.674 \\
\hline & $(39.736)$ & $(0.719)$ & $(0.300)$ & $(8.336)$ & $(0.865)$ & $(0.366)$ & $(0.479)$ \\
\hline \multirow[t]{2}{*}{ AUD } & 0.132 & -0.299 & 0.021 & -0.293 & -0.331 & $0.193 * *$ & -0.057 \\
\hline & $(2.295)$ & $(0.886)$ & $(0.022)$ & $(3.920)$ & $(0.290)$ & $(0.079)$ & $(0.171)$ \\
\hline \multirow[t]{2}{*}{ MYR } & -13.005 & -1.024 & 0.032 & 0.281 & $0.758 * *$ & 97.395 & -0.308 \\
\hline & $(111.192)$ & $(3.033)$ & $(0.104)$ & $(3.594)$ & $(0.352)$ & $(88.278)$ & $(0.660)$ \\
\hline \multirow{2}{*}{$\begin{array}{l}\text { Deutsche } \\
\text { Mark }\end{array}$} & -0.986 & 0.720 & 0.080 & -0.336 & 0.384 & & \\
\hline & $(8.536)$ & $(1.914)$ & $(0.117)$ & $(5.096)$ & $(0.463)$ & & \\
\hline \multirow[t]{2}{*}{ EUR } & & & & & & 0.155 & -0.138 \\
\hline & & & & & & $(0.332)$ & $(0.228)$ \\
\hline \multirow[t]{2}{*}{ Constant } & 0.025 & -0.021 & -0.002 & 0.011 & 0.004 & -0.003 & $-0.012^{* *}$ \\
\hline & $(0.244)$ & $(0.057)$ & $(0.006)$ & $(0.152)$ & $(0.007)$ & $(0.005)$ & $(0.005)$ \\
\hline Observations & 46 & 48 & 48 & 48 & 36 & 48 & 37 \\
\hline GBP & 3.412 & 0.285 & 0.004 & -0.060 & 0.136 & -0.094 & 0.403 \\
\hline
\end{tabular}

\subsection{Western Samoa tala (Wst)}

\section{IV: Price of coconuts}

\begin{tabular}{|c|c|c|c|c|c|c|c|}
\hline (1) & (2) & (3) & (4) & (5) & (6) & (7) & \\
\hline & wst $80-83$ & $84-87$ & $88-91$ & $92-95$ & 96-99 & $00-03$ & 04-07 \\
\hline \multirow{2}{*}{$\begin{array}{l}{[\Delta \operatorname{Res} / \mathrm{MB}+} \\
\Delta \log \mathrm{Ex}]\end{array}$} & 0.072 & 0.034 & 0.080 & 0.176 & -0.202 & -0.123 & 0.006 \\
\hline & $(0.561)$ & $(0.365)$ & $(0.152)$ & $(0.249)$ & $(0.335)$ & $(0.191)$ & $(0.037)$ \\
\hline \multirow[t]{2}{*}{ JPY } & 0.639 & 0.189 & $0.261^{* *}$ & 0.361 & -0.060 & -0.316 & 0.002 \\
\hline & (4.799) & $(0.153)$ & $(0.117)$ & $(0.449)$ & $(0.270)$ & $(0.510)$ & $(0.049)$ \\
\hline \multirow[t]{2}{*}{ USD } & 0.354 & -0.264 & 0.740 & 0.979 & 0.931 & 0.000 & $0.488^{* *}$ \\
\hline & $(1.178)$ & $(0.809)$ & $(1.224)$ & $(0.768)$ & $(0.655)$ & $(0.000)$ & $(0.179)$ \\
\hline \multirow[t]{2}{*}{ KRW } & 0.053 & 0.592 & $-0.363^{*}$ & -0.025 & -0.068 & -0.090 & 0.001 \\
\hline & $(2.322)$ & $(0.961)$ & $(0.211)$ & $(0.485)$ & $(0.140)$ & $(0.176)$ & $(0.121)$ \\
\hline \multirow[t]{2}{*}{ SGD } & -2.043 & 0.008 & -0.074 & -0.494 & -0.354 & 0.598 & 0.030 \\
\hline & $(16.441)$ & $(0.883)$ & $(0.169)$ & $(0.622)$ & $(0.393)$ & $(0.812)$ & $(0.223)$ \\
\hline \multirow[t]{2}{*}{ AUD } & 0.695 & -0.049 & 0.108 & 0.015 & -0.085 & 0.603 & $0.193^{*}$ \\
\hline & $(3.173)$ & $(0.165)$ & $(0.079)$ & $(0.167)$ & $(0.238)$ & $(0.498)$ & $(0.099)$ \\
\hline \multirow[t]{2}{*}{ NZD } & -0.329 & $0.481^{*}$ & $0.487 * * *$ & -0.001 & 0.834 & $0.276^{*}$ & $0.270 * * *$ \\
\hline & $(7.313)$ & $(0.273)$ & $(0.128)$ & $(0.684)$ & $(0.529)$ & $(0.140)$ & $(0.084)$ \\
\hline \multirow[t]{2}{*}{ MYR } & 2.521 & 0.004 & -0.275 & -0.021 & 0.193 & -0.150 & -0.052 \\
\hline & $(19.180)$ & $(0.665)$ & (1.009) & $(0.146)$ & $(0.206)$ & $(0.890)$ & $(0.292)$ \\
\hline \multirow{2}{*}{$\begin{array}{l}\text { Deutsche } \\
\text { Mark }\end{array}$} & -0.728 & -0.064 & 0.051 & 0.122 & -0.120 & & \\
\hline & $(5.316)$ & $(0.279)$ & $(0.555)$ & $(0.268)$ & $(0.446)$ & & \\
\hline EUR & & & & & & -0.189 & 0.087 \\
\hline
\end{tabular}




\begin{tabular}{|l|l|l|l|l|l|l|l|}
\hline & & & & & & $(0.485)$ & $(0.069)$ \\
\hline Constant & -0.018 & -0.008 & -0.004 & 0.002 & 0.001 & 0.000 & 0.000 \\
\hline & $(0.062)$ & $(0.015)$ & $(0.004)$ & $(0.006)$ & $(0.004)$ & $(0.003)$ & $(0.002)$ \\
\hline Observations & 40 & 48 & 48 & 48 & 36 & 48 & 41 \\
\hline GBP & -0.162 & 0.104 & 0.064 & 0.064 & -0.269 & 0.267 & -0.018 \\
\hline
\end{tabular}

\subsection{Australia (aud)}

\section{IV: world commodity price index}

\begin{tabular}{|l|l|l|l|l|}
\hline & $(1)$ & $(2)$ & $(3)$ & $(4)$ \\
\hline & aud 92-95 & $96-99$ & $00-03$ & $04-07$ \\
\hline$[\Delta$ Res/MB $+\Delta \operatorname{logEx}]$ & $0.288^{* *}$ & 0.457 & 0.609 & 0.181 \\
\hline & $(0.115)$ & $(0.479)$ & $(0.904)$ & $(0.394)$ \\
\hline JPY & 0.013 & $0.201^{*}$ & 0.114 & 0.270 \\
\hline & $(0.103)$ & $(0.109)$ & $(0.343)$ & $(0.321)$ \\
\hline USD & $1.002^{* * *}$ & $0.563^{*}$ & 0.652 & 0.215 \\
\hline & $(0.095)$ & $(0.286)$ & $(0.890)$ & $(0.198)$ \\
\hline Deutsche Mark & -0.153 & -0.036 & & \\
\hline & $(0.146)$ & $(0.351)$ & & \\
\hline EUR & & & 0.469 & 0.335 \\
\hline & & & $(0.328)$ & $(0.754)$ \\
\hline Constant & 0.003 & -0.006 & -0.005 & -0.003 \\
\hline & $(0.002)$ & $(0.005)$ & $(0.010)$ & $(0.010)$ \\
\hline Observations & 48 & 36 & 48 & 41 \\
\hline R-squared & 0.853 & 0.181 & & \\
\hline GBP & 0.138 & 0.272 & -0.235 & 0.181 \\
\hline
\end{tabular}

Notes:

1. The level of commodity prices (thought of as a determinant of the balance of payments) is used as instrumental variables for the change in EMP

2. Commodity prices have been converted to SDR

3. The commodity prices have been deflated by the weighted world CPI:

we calculate the weighted CPI by using the weights and currencies that are used to define SDR, and have adjusted their weights according to their evolution since 1980

4. Data source: IMF International Financial Statistics

5. Indices of Unit Values (Prices) In Terms of US Dollars: $2000=100$

\subsection{Canadian dollar (cad)}

IV: world commodity price index

\begin{tabular}{|c|c|c|c|c|c|}
\hline & $(1)$ & (2) & (3) & (4) & $(5)$ \\
\hline & cad 90-93 & $94-97$ & $98-01$ & $02-05$ & 06-07 \\
\hline \multirow[t]{2}{*}{$\Delta \operatorname{Res} / \mathrm{MB}+\Delta \log \mathrm{Ex}$} & 0.378 & 0.383 & 0.186 & 0.591 & 1.231 \\
\hline & $(0.322)$ & $(1.376)$ & $(0.101)$ & $(0.573)$ & $(0.721)$ \\
\hline \multirow[t]{2}{*}{ JPY } & 0.252 & 0.057 & 0.070 & $0.318 * * *$ & -0.180 \\
\hline & $(0.288)$ & $(0.194)$ & $(0.153)$ & $(0.109)$ & $(0.709)$ \\
\hline \multirow[t]{2}{*}{ USD } & 0.616 & 0.733 & 0.207 & 0.364 & 0.077 \\
\hline & $(0.377)$ & $(1.058)$ & $(0.426)$ & $(0.264)$ & $(0.795)$ \\
\hline \multirow[t]{2}{*}{ Deutsche Mark } & 0.287 & 0.076 & 0.081 & & \\
\hline & $(0.395)$ & $(0.318)$ & $(0.374)$ & & \\
\hline \multirow[t]{2}{*}{ EUR } & & & & $0.351 *$ & -0.113 \\
\hline & & & & $(0.192)$ & $(0.602)$ \\
\hline \multirow[t]{2}{*}{ Constant } & -0.002 & -0.006 & -0.008 & 0.004 & -0.015 \\
\hline & $(0.002)$ & $(0.019)$ & $(0.006)$ & $(0.002)$ & $(0.014)$ \\
\hline Observations & 48 & 48 & 8 & 48 & 13 \\
\hline R-squared & 0.862 & 0.188 & 0.657 & 0.644 & \\
\hline GBP & -0.155 & 0.133 & 0.641 & -0.034 & 1.216 \\
\hline
\end{tabular}




\subsection{Mexico (mxn)}

IV: oil price

\begin{tabular}{|l|l|l|l|l|l|l|l|}
\hline & $(1)$ & $(2)$ & $(3)$ & $(4)$ & $(5)$ & $(6)$ & $(7)$ \\
\hline & mxn 80-83 & $84-87$ & $88-91$ & $92-95$ & $96-99$ & $00-03$ & $04-07$ \\
\hline $\begin{array}{l}{[\Delta \text { Res/MB }+} \\
\Delta \operatorname{logEx}]\end{array}$ & $1.092^{* * *}$ & 2.745 & $-0.046^{*}$ & 0.686 & 0.104 & 1.151 & 0.200 \\
\hline & $(0.127)$ & $(5.766)$ & $(0.027)$ & $(0.963)$ & $(0.170)$ & $(3.335)$ & $(0.501)$ \\
\hline JPY & 0.113 & 0.855 & 0.078 & 0.930 & 0.048 & 0.936 & 0.209 \\
\hline & $(0.129)$ & $(1.847)$ & $(0.079)$ & $(1.110)$ & $(0.069)$ & $(3.205)$ & $(0.368)$ \\
\hline USD & $0.384^{* *}$ & -1.975 & $0.996^{* * *}$ & -0.235 & $1.383^{* * *}$ & -0.649 & 0.626 \\
\hline & $(0.186)$ & $(6.982)$ & $(0.036)$ & $(1.923)$ & $(0.331)$ & $(5.615)$ & $(0.987)$ \\
\hline $\begin{array}{l}\text { Deutsche } \\
\text { Mark }\end{array}$ & $0.475^{* * *}$ & 3.807 & -0.089 & -0.144 & -0.210 & & \\
\hline & $(0.156)$ & $(10.691)$ & $(0.076)$ & $(1.397)$ & $(0.167)$ & & 1.363 \\
\hline EUR & & & & & & $(4.263)$ & $(0.711)$ \\
\hline & & & & & & -0.027 & -0.002 \\
\hline Constant & -0.000 & 0.029 & $-0.007 * * *$ & -0.014 & -0.011 & $(0.069)$ & $(0.006)$ \\
\hline & $(0.004)$ & $(0.146)$ & $(0.001)$ & $(0.018)$ & $(0.008)$ & 48 & 41 \\
\hline Observations & 46 & 48 & 48 & 48 & 36 & 48 & 0.537 \\
\hline R-squared & 0.954 & & 0.953 & & 0.722 & & 0.376 \\
\hline GBP & 0.027 & -1.686 & 0.015 & 0.449 & -0.220 & -0.650 & \\
\hline
\end{tabular}

\subsection{Indonesia (idr)}

IV: average price of oil and gas

\begin{tabular}{|l|l|l|l|l|}
\hline & $(1)$ & $(2)$ & $(5)$ & $(4)$ \\
\hline & idr 92-95 & $96-99$ & $00-05$ & $04-07$ \\
\hline$[\Delta$ Res/MB $+\Delta \log \mathrm{Ex}]$ & 0.000 & -0.005 & 0.000 & 0.000 \\
\hline & $(0.001)$ & $(0.052)$ & $(0.000)$ & $(0.001)$ \\
\hline JPY & -0.095 & -0.045 & -0.250 & -0.289 \\
\hline & $(0.266)$ & $(4.222)$ & $(0.292)$ & $(0.271)$ \\
\hline USD & -0.592 & 4.245 & $-1.569 * * *$ & 0.865 \\
\hline KRW & $(5.225)$ & $(57.251)$ & $(0.476)$ & $(2.556)$ \\
\hline & 0.029 & 2.779 & 0.154 & -0.029 \\
\hline SGD & $(0.277)$ & $(19.712)$ & $(0.250)$ & $(0.427)$ \\
\hline & 0.061 & 0.807 & $2.054 * * *$ & 0.721 \\
\hline AUD & $(0.550)$ & $(10.127)$ & $(0.729)$ & $(0.800)$ \\
\hline & -0.012 & -0.605 & 0.144 & 0.528 \\
\hline MYR & $(0.075)$ & $(4.802)$ & $(0.282)$ & $(0.601)$ \\
\hline & -0.054 & -1.277 & 0.000 & -0.556 \\
\hline THB & $(0.127)$ & $(17.121)$ & $(0.000)$ & $(2.017)$ \\
\hline & 1.471 & -0.582 & 0.405 & 0.675 \\
\hline Deutsche Mark & $(5.468)$ & $(7.020)$ & $(0.454)$ & $(0.405)$ \\
\hline & 0.055 & 1.065 & & \\
\hline EUR & $(0.142)$ & $(10.556)$ & & -0.524 \\
\hline & & & -0.016 & $(0.405)$ \\
\hline Constant & & & -0.004 & -0.008 \\
\hline & -0.005 & 0.096 & $(0.008)$ & $(0.006)$ \\
\hline Observations & $(0.005)$ & $(0.758)$ & 48 & 41 \\
\hline R-squared & 47 & 56 & 0.410 & 0.541 \\
\hline GBP & 0.950 & -5.591 & -0.102 & -0.590 \\
\hline & -0.060 & & \\
\hline
\end{tabular}

\footnotetext{
* Statistically significant at .10 level

$* *$ Statistically significant at $\mathbf{0 5}$ level $* * *$ Statistically significant at .01 level
} 
Table 6: Extension 1

Estimating the De Facto Exchange Rate Regime

By allowing for trends in level and in the currency weights

$(01 / 1980-06 / 2007) \quad$ numeraire currency $=$ SDR

6.1 China (cny)

\begin{tabular}{|c|c|}
\hline & $(1)$ \\
\hline & Cny $05-08$ \\
\hline \multirow[t]{2}{*}{ EUR } & 0.006 \\
\hline & $(0.052)$ \\
\hline \multirow[t]{2}{*}{ USD } & 1.070 \\
\hline & $(1.917)$ \\
\hline \multirow[t]{2}{*}{ JPY } & 0.029 \\
\hline & $(0.025)$ \\
\hline \multirow[t]{2}{*}{ t_usd } & 0.000 \\
\hline & $(0.006)$ \\
\hline \multirow[t]{2}{*}{ KRW } & 0.060 \\
\hline & $(0.041)$ \\
\hline \multirow[t]{2}{*}{ SGD } & $-0.132^{*}$ \\
\hline & $(0.067)$ \\
\hline \multirow[t]{2}{*}{ MYR } & 0.009 \\
\hline & $(0.036)$ \\
\hline \multirow[t]{2}{*}{ RUB } & -0.091 \\
\hline & $(0.094)$ \\
\hline \multirow[t]{2}{*}{ AUD } & -0.010 \\
\hline & $(0.024)$ \\
\hline \multirow[t]{2}{*}{ THB } & 0.053 \\
\hline & $(0.031)$ \\
\hline \multirow[t]{2}{*}{ CAD } & -0.032 \\
\hline & $(0.026)$ \\
\hline \multirow[t]{2}{*}{ Constant } & $-0.070 * *$ \\
\hline & $(0.025)$ \\
\hline \multirow[t]{2}{*}{$\mathrm{t} 2$} & $2.284 * *$ \\
\hline & $(0.801)$ \\
\hline \multirow[t]{2}{*}{$\Delta[\log E M P]$} & 0.004 \\
\hline & $(0.043)$ \\
\hline Observations & 23 \\
\hline R-squared & 0.997 \\
\hline GBP & 0.038 \\
\hline
\end{tabular}

Notes:

1. $t 2=$ observation $/ 10,000$

2. t_currency $=$ observation $*$ currency value

3. $\Delta[\log E M P]=\Delta[\log R e s+\log E x]$

6.6 Danish krone (dkk)

\begin{tabular}{|l|l|l|l|l|l|l|l|}
\hline & $(1)$ & $(2)$ & $(3)$ & $(4)$ & $(5)$ & $(6)$ & $(7)$ \\
\hline & dkk 80-83 & $84-87$ & $88-91$ & $92-95$ & $96-99$ & $00-03$ & $04-07$ \\
\hline JPY & $-0.215^{*}$ & 0.008 & $1.974^{* * *}$ & -0.647 & 0.289 & -0.320 & 0.448 \\
\hline & $(0.114)$ & $(0.315)$ & $(0.456)$ & $(0.434)$ & $(0.192)$ & $(0.559)$ & $(0.350)$ \\
\hline USD & -0.092 & 0.267 & $-0.673^{* * *}$ & $1.020^{* *}$ & 0.431 & -0.023 & -0.493 \\
\hline & $(0.093)$ & $(0.272)$ & $(0.214)$ & $(0.467)$ & $(0.342)$ & $(0.350)$ & $(0.612)$ \\
\hline French franc & $1.347^{* * *}$ & $1.295^{* * *}$ & $1.349^{* * *}$ & & & & \\
\hline & $(0.136)$ & $(0.392)$ & $(0.408)$ & & & & \\
\hline t jpy & $0.017^{* * *}$ & 0.001 & $-0.016^{* * *}$ & 0.004 & -0.001 & 0.001 & -0.001 \\
\hline & $(0.006)$ & $(0.004)$ & $(0.004)$ & $(0.003)$ & $(0.001)$ & $(0.002)$ & $(0.001)$ \\
\hline
\end{tabular}




\begin{tabular}{|c|c|c|c|c|c|c|c|}
\hline \multirow[t]{2}{*}{ t_usd } & $0.009^{*}$ & -0.004 & $0.006^{* * *}$ & $-0.006^{* *}$ & -0.002 & 0.000 & 0.002 \\
\hline & $(0.005)$ & $(0.003)$ & $(0.002)$ & $(0.003)$ & $(0.002)$ & $(0.001)$ & $(0.002)$ \\
\hline \multirow{2}{*}{$\begin{array}{l}\text { t_French } \\
\text { franc }\end{array}$} & $-0.027 * * *$ & -0.006 & -0.003 & & & & \\
\hline & $(0.008)$ & $(0.005)$ & $(0.003)$ & & & & \\
\hline \multirow[t]{2}{*}{$\mathrm{t} 2$} & $-3.670 * *$ & -0.444 & 0.457 & 0.752 & -0.104 & -0.370 & -0.223 \\
\hline & $(1.447)$ & $(0.730)$ & $(0.500)$ & $(0.792)$ & $(0.300)$ & $(0.528)$ & $(0.259)$ \\
\hline \multirow[t]{2}{*}{$\Delta[\log \mathrm{EMP}]$} & -0.029 & 0.018 & 0.014 & 0.023 & 0.002 & 0.005 & -0.001 \\
\hline & $(0.019)$ & $(0.012)$ & $(0.011)$ & $(0.022)$ & $(0.005)$ & $(0.011)$ & $(0.007)$ \\
\hline \multirow[t]{2}{*}{$\begin{array}{l}\text { German } \\
\text { mark }\end{array}$} & & & & $1.853 * * *$ & 0.201 & & \\
\hline & & & & $(0.561)$ & $(0.345)$ & & \\
\hline \multirow[t]{2}{*}{ EUR } & & & & & & $1.477 * * *$ & -0.663 \\
\hline & & & & & & $(0.361)$ & $(0.954)$ \\
\hline \multirow[t]{2}{*}{$t$ _eur } & & & & & & -0.002 & $0.005^{*}$ \\
\hline & & & & & & $(0.001)$ & $(0.003)$ \\
\hline \multirow[t]{2}{*}{ Constant } & $0.007^{*}$ & 0.002 & -0.004 & -0.012 & 0.002 & 0.010 & 0.007 \\
\hline & $(0.004)$ & $(0.005)$ & $(0.006)$ & $(0.014)$ & $(0.006)$ & $(0.014)$ & $(0.008)$ \\
\hline \multirow[t]{2}{*}{$\begin{array}{l}\text { t_German } \\
\text { mark }\end{array}$} & & & & -0.006 & $0.004 * *$ & & \\
\hline & & & & $(0.004)$ & $(0.002)$ & & \\
\hline Observations & 46 & 48 & 48 & 48 & 36 & 48 & 41 \\
\hline R-squared & 0.908 & 0.865 & 0.946 & 0.846 & 0.992 & 0.983 & 0.971 \\
\hline GBP & -0.040 & -0.569 & -1.650 & -1.225 & 0.079 & -0.133 & 1.708 \\
\hline
\end{tabular}

\subsection{Latvian lat (lv1)}

\begin{tabular}{|c|c|c|c|c|}
\hline & $(1)$ & $(2)$ & (3) & (4) \\
\hline & lvl 92-95 & $96-99$ & $00-03$ & 04-07 \\
\hline \multirow[t]{2}{*}{ JPY } & -3.037 & $0.752 * *$ & 0.165 & 1.147 \\
\hline & $(2.372)$ & $(0.283)$ & $(0.631)$ & $(2.151)$ \\
\hline \multirow[t]{2}{*}{ USD } & 5.144 & 0.770 & $2.197 * * *$ & 1.993 \\
\hline & $(4.026)$ & $(1.890)$ & $(0.760)$ & $(3.486)$ \\
\hline \multirow[t]{2}{*}{ RUB } & 0.110 & -0.765 & $-1.932 * *$ & -4.694 \\
\hline & $(0.983)$ & $(1.743)$ & $(0.788)$ & $(5.805)$ \\
\hline \multirow[t]{2}{*}{ German mark } & 0.453 & -0.900 & & \\
\hline & $(4.168)$ & $(0.778)$ & & \\
\hline \multirow[t]{2}{*}{ t_jpy } & 0.018 & $-0.003^{*}$ & -0.000 & -0.004 \\
\hline & $(0.013)$ & $(0.001)$ & $(0.002)$ & $(0.007)$ \\
\hline \multirow[t]{2}{*}{ t_usd } & -0.025 & -0.001 & $-0.007 * *$ & -0.007 \\
\hline & $(0.021)$ & $(0.009)$ & $(0.003)$ & $(0.012)$ \\
\hline \multirow[t]{2}{*}{ t_rub } & -0.001 & 0.003 & $0.008 * *$ & 0.017 \\
\hline & $(0.005)$ & $(0.008)$ & $(0.003)$ & $(0.020)$ \\
\hline \multirow[t]{2}{*}{ t_German mark } & -0.001 & 0.006 & & \\
\hline & $(0.023)$ & $(0.004)$ & & \\
\hline \multirow[t]{2}{*}{ EUR } & & & -0.446 & 1.545 \\
\hline & & & $(0.498)$ & $(4.280)$ \\
\hline \multirow[t]{2}{*}{ t_eur } & & & 0.003 & -0.004 \\
\hline & & & $(0.002)$ & $(0.014)$ \\
\hline \multirow[t]{2}{*}{$\mathrm{t} 2$} & -3.840 & 1.020 & -0.281 & 0.098 \\
\hline & $(4.310)$ & $(2.031)$ & $(0.532)$ & $(1.373)$ \\
\hline \multirow[t]{2}{*}{$\Delta[\log \mathrm{EMP}]$} & 0.029 & 0.021 & 0.011 & 0.033 \\
\hline & $(0.024)$ & $(0.013)$ & $(0.016)$ & $(0.030)$ \\
\hline \multirow[t]{2}{*}{ Constant } & 0.073 & -0.023 & 0.007 & -0.006 \\
\hline & $(0.080)$ & $(0.044)$ & $(0.014)$ & $(0.041)$ \\
\hline Observations & 16 & 36 & 48 & 42 \\
\hline R-squared & 0.953 & 0.964 & 0.941 & 0.629 \\
\hline GBP & -1.670 & 1.143 & 1.016 & 1.009 \\
\hline
\end{tabular}




\subsection{Maltese lira (mtl)}

\begin{tabular}{|c|c|c|c|c|c|c|c|}
\hline & (1) & (2) & (3) & (4) & (5) & (6) & (7) \\
\hline & $\mathrm{mtl} 80-83$ & $84-87$ & $88-91$ & $92-95$ & $96-99$ & $00-03$ & 04-07 \\
\hline \multirow[t]{2}{*}{ JPY } & -0.115 & 0.153 & 0.539 & -0.230 & 2.178 & -0.050 & -0.756 \\
\hline & $(0.109)$ & $(0.230)$ & $(0.423)$ & $(0.632)$ & $(3.207)$ & $(0.391)$ & $(0.564)$ \\
\hline \multirow[t]{2}{*}{ USD } & $0.355 * * *$ & $0.834 * * *$ & $0.501 * *$ & 0.629 & $-8.397 *$ & $1.967 * * *$ & $2.174 * *$ \\
\hline & $(0.088)$ & $(0.175)$ & $(0.225)$ & $(0.823)$ & $(4.491)$ & $(0.362)$ & $(0.821)$ \\
\hline \multirow[t]{2}{*}{ French franc } & $0.432 * * *$ & -0.076 & 0.216 & & & & \\
\hline & $(0.089)$ & $(0.335)$ & $(0.332)$ & & & & \\
\hline \multirow[t]{2}{*}{ t_jpy } & $0.009 * *$ & -0.001 & -0.004 & 0.002 & -0.009 & 0.000 & 0.002 \\
\hline & $(0.004)$ & $(0.003)$ & $(0.003)$ & $(0.004)$ & $(0.014)$ & $(0.002)$ & $(0.002)$ \\
\hline \multirow[t]{2}{*}{ t_usd } & 0.003 & $-0.008 * * *$ & -0.002 & -0.002 & $0.042 *$ & $-0.007 * * *$ & $-0.007 * *$ \\
\hline & $(0.003)$ & $(0.002)$ & $(0.002)$ & $(0.005)$ & $(0.022)$ & $(0.001)$ & $(0.003)$ \\
\hline \multirow[t]{2}{*}{$\begin{array}{l}\text { t_French } \\
\text { franc }\end{array}$} & $-0.009 * * *$ & $0.007 *$ & 0.001 & & & & \\
\hline & $(0.003)$ & $(0.004)$ & $(0.003)$ & & & & \\
\hline \multirow[t]{2}{*}{$\begin{array}{l}\text { German } \\
\text { mark }\end{array}$} & & & & 0.706 & $5.671 * *$ & & \\
\hline & & & & $(1.203)$ & $(2.084)$ & & \\
\hline \multirow[t]{2}{*}{ EUR } & & & & & & $-0.921 * *$ & -1.088 \\
\hline & & & & & & $(0.340)$ & $(1.383)$ \\
\hline \multirow[t]{2}{*}{$t$ eur } & & & & & & $0.006^{* * *}$ & 0.006 \\
\hline & & & & & & $(0.001)$ & $(0.004)$ \\
\hline \multirow[t]{2}{*}{$\begin{array}{l}\text { t_German } \\
\text { mark }\end{array}$} & & & & -0.002 & $-0.026^{* *}$ & & \\
\hline & & & & $(0.007)$ & $(0.011)$ & & \\
\hline \multirow[t]{2}{*}{$\mathrm{t} 2$} & -1.375 & -0.510 & 0.351 & 2.181 & -1.211 & 0.016 & 0.119 \\
\hline & $(1.051)$ & $(0.608)$ & $(0.422)$ & $(1.739)$ & $(1.961)$ & $(0.498)$ & $(0.443)$ \\
\hline \multirow[t]{2}{*}{$\Delta[\log \mathrm{EMP}]$} & 0.039 & 0.101 & 0.041 & 0.219 & $0.598 * * *$ & $0.062 * *$ & 0.022 \\
\hline & $(0.026)$ & $(0.090)$ & $(0.036)$ & $(0.170)$ & $(0.161)$ & $(0.029)$ & $(0.024)$ \\
\hline \multirow[t]{2}{*}{ Constant } & 0.004 & 0.003 & -0.004 & -0.039 & 0.026 & -0.001 & -0.004 \\
\hline & $(0.003)$ & $(0.004)$ & $(0.005)$ & $(0.031)$ & $(0.044)$ & $(0.013)$ & $(0.014)$ \\
\hline Observations & 46 & 48 & 48 & 48 & 36 & 45 & 41 \\
\hline R-squared & 0.899 & 0.942 & 0.947 & 0.608 & 0.760 & 0.962 & 0.911 \\
\hline GBP & 0.328 & 0.089 & -0.257 & -0.106 & 1.548 & 0.004 & 0.670 \\
\hline
\end{tabular}

\subsection{Norwegian kroner (nok)}

\begin{tabular}{|l|l|l|l|l|l|l|l|}
\hline & $(1)$ & $(2)$ & $(3)$ & $(4)$ & $(5)$ & $(6)$ & $(7)$ \\
\hline & nok 80-83 & $84-87$ & $88-91$ & $92-95$ & $96-99$ & $00-03$ & $04-07$ \\
\hline JPY & -0.226 & 0.444 & $2.307 * * *$ & -0.637 & -0.037 & 0.140 & -1.575 \\
\hline & $(0.160)$ & $(0.346)$ & $(0.682)$ & $(0.530)$ & $(0.850)$ & $(1.846)$ & $(3.651)$ \\
\hline USD & $0.323^{* * *}$ & 0.031 & 0.262 & 0.391 & 1.064 & 0.631 & 5.032 \\
\hline & $(0.115)$ & $(0.470)$ & $(0.286)$ & $(0.529)$ & $(2.637)$ & $(2.511)$ & $(3.519)$ \\
\hline French franc & $0.894^{* * *}$ & $0.704^{*}$ & -0.773 & & & & \\
\hline & $(0.126)$ & $(0.400)$ & $(0.834)$ & & & & \\
\hline t_jpy & $0.020^{* * *}$ & -0.005 & $-0.018^{* * *}$ & 0.004 & -0.000 & -0.000 & 0.006 \\
\hline & $(0.006)$ & $(0.004)$ & $(0.006)$ & $(0.003)$ & $(0.004)$ & $(0.007)$ & $(0.012)$ \\
\hline t_usd & 0.003 & 0.000 & -0.001 & -0.002 & -0.004 & -0.002 & -0.017 \\
\hline & $(0.005)$ & $(0.007)$ & $(0.002)$ & $(0.003)$ & $(0.013)$ & $(0.010)$ & $(0.011)$ \\
\hline t_Fr. franc & $-0.027 * * *$ & 0.000 & 0.011 & & & & \\
\hline & $(0.006)$ & $(0.005)$ & $(0.007)$ & & & & \\
\hline Ger. mark & & & & $3.005^{* * *}$ & -0.343 & & \\
\hline & & & & $(1.008)$ & $(2.127)$ & & \\
\hline t_G. mark & & & $-0.014 * *$ & 0.006 & & \\
\hline
\end{tabular}




\begin{tabular}{|l|l|l|l|l|l|l|l|}
\hline & & & & $(0.006)$ & $(0.010)$ & & \\
\hline EUR & & & & & & -2.259 & 5.779 \\
\hline & & & & & & $(2.733)$ & $(5.261)$ \\
\hline t_eur & & & & & & 0.012 & -0.015 \\
\hline & & & & & & $(0.011)$ & $(0.017)$ \\
\hline $\mathrm{t} 2$ & $-4.883^{* * *}$ & 0.673 & 0.490 & 1.974 & -2.674 & -2.348 & -1.183 \\
\hline & $(1.655)$ & $(1.212)$ & $(0.717)$ & $(1.306)$ & $(2.111)$ & $(2.307)$ & $(2.530)$ \\
\hline$\Delta[\operatorname{logEMP}]$ & $0.039^{*}$ & $0.107^{*}$ & $0.050^{*}$ & $0.060^{*}$ & 0.062 & 0.010 & $0.082^{*}$ \\
\hline & $(0.021)$ & $(0.060)$ & $(0.026)$ & $(0.035)$ & $(0.038)$ & $(0.049)$ & $(0.046)$ \\
\hline Constant & $0.007^{*}$ & -0.010 & -0.005 & -0.034 & 0.055 & 0.061 & 0.038 \\
\hline & $(0.004)$ & $(0.009)$ & $(0.009)$ & $(0.023)$ & $(0.043)$ & $(0.059)$ & $(0.079)$ \\
\hline Observations & 46 & 48 & 48 & 48 & 36 & 48 & 42 \\
\hline R-squared & 0.814 & 0.774 & 0.864 & 0.823 & 0.804 & 0.658 & 0.587 \\
\hline GBP & 0.009 & -0.179 & -0.796 & -1.760 & 0.316 & 2.489 & -8.235 \\
\hline
\end{tabular}

\subsection{Russia (rub)}

\begin{tabular}{|l|l|l|l|l|}
\hline & $(1)$ & $(2)$ & $(3)$ & $(4)$ \\
\hline & rub 92-95 & $96-99$ & $00-03$ & $04-07$ \\
\hline JPY & -55.359 & -8.026 & 2.014 & $2.132^{*}$ \\
\hline & $(46.199)$ & $(6.905)$ & $(1.546)$ & $(1.056)$ \\
\hline USD & -35.260 & -42.904 & -0.419 & 2.101 \\
\hline & $(65.462)$ & $(25.901)$ & $(1.302)$ & $(1.374)$ \\
\hline German mark & -55.747 & 28.974 & & \\
\hline & $(41.391)$ & $(19.384)$ & & $-0.007^{*}$ \\
\hline t_jpy & 0.294 & 0.037 & -0.008 & $(0.004)$ \\
\hline & $(0.248)$ & $(0.032)$ & $(0.006)$ & -0.005 \\
\hline t_usd & 0.189 & $0.221^{*}$ & 0.005 & $(0.004)$ \\
\hline & $(0.347)$ & $(0.129)$ & $(0.005)$ & \\
\hline t_German mark & 0.300 & -0.142 & & $-8.006^{* * *}$ \\
\hline & $(0.227)$ & $(0.095)$ & & $(2.539)$ \\
\hline EUR & & & $1.986^{*}$ & $0.027^{* * *}$ \\
\hline & & & $(1.171)$ & $(0.008)$ \\
\hline t_eur & & & $-0.008^{*}$ & -0.461 \\
\hline & & & $(0.004)$ & $(0.761)$ \\
\hline t2 & -10.071 & -18.877 & $4.448^{* * *}$ & $0.076^{* *}$ \\
\hline & $(35.121)$ & $(11.763)$ & $(1.218)$ & $(0.034)$ \\
\hline$\Delta[$ logEMP] & 0.249 & $0.287^{* * *}$ & $0.134^{* * *}$ & 0.013 \\
\hline & $(0.280)$ & $(0.083)$ & $(0.028)$ & $(0.023)$ \\
\hline Constant & 0.167 & 0.373 & $-0.123^{* * *}$ & 42 \\
\hline & $(0.665)$ & $(0.245)$ & $(0.033)$ & 0.885 \\
\hline Observations & 11 & 36 & 48 & 4.773 \\
\hline R-squared & 0.873 & 0.721 & 0.926 & \\
\hline GBP & 147.365 & 22.956 & -2.580 & \\
\hline & & & & \\
\hline
\end{tabular}

\subsection{Seychelles rupee (scr)}

\begin{tabular}{|l|l|l|l|l|l|l|l|}
\hline & $(1)$ & $(2)$ & $(3)$ & $(4)$ & $(5)$ & $(6)$ & $(7)$ \\
\hline & scr $80-83$ & $84-87$ & $88-91$ & $92-95$ & $96-99$ & $00-03$ & $04-07$ \\
\hline JPY & -0.411 & -0.069 & $0.406^{*}$ & 0.062 & 1.209 & 0.288 & -0.795 \\
\hline & $(0.435)$ & $(0.108)$ & $(0.233)$ & $(0.200)$ & $(1.197)$ & $(2.232)$ & $(2.336)$ \\
\hline USD & $0.383^{* * *}$ & $0.941^{* * *}$ & -0.169 & $0.533^{* * *}$ & -2.579 & -0.561 & 3.901 \\
\hline & $(0.136)$ & $(0.090)$ & $(0.135)$ & $(0.159)$ & $(2.938)$ & $(2.731)$ & $(2.574)$ \\
\hline French franc & $0.579^{* * *}$ & $0.295^{*}$ & $0.722^{* * *}$ & & & & \\
\hline & $(0.190)$ & $(0.156)$ & $(0.162)$ & & & & \\
\hline t jpy & 0.016 & $0.003^{* *}$ & -0.002 & 0.001 & -0.005 & 0.000 & 0.003 \\
\hline
\end{tabular}




\begin{tabular}{|c|c|c|c|c|c|c|c|}
\hline & $\begin{array}{l}(0.012) \\
\end{array}$ & $(0.001)$ & $(0.002)$ & $(0.001)$ & $(0.005)$ & $(0.008)$ & $(0.008)$ \\
\hline \multirow[t]{2}{*}{ t_ usd } & 0.002 & $-0.007 * * *$ & $0.005 * * *$ & -0.001 & 0.015 & 0.003 & -0.010 \\
\hline & $(0.005)$ & $(0.001)$ & $(0.001)$ & $(0.001)$ & $(0.015)$ & $(0.010)$ & $(0.009)$ \\
\hline \multirow[t]{2}{*}{ t_Fr. franc } & $-0.011^{*}$ & 0.000 & $-0.003^{* *}$ & & & & \\
\hline & $(0.006)$ & $(0.002)$ & $(0.001)$ & & & & \\
\hline \multirow[t]{2}{*}{ t2 } & -4.150 & 0.083 & 0.170 & -0.031 & -1.871 & -2.320 & $-3.870^{* * *}$ \\
\hline & $(4.002)$ & $(0.276)$ & $(0.192)$ & $(0.325)$ & $(1.793)$ & $(2.342)$ & $(1.627)$ \\
\hline \multirow[t]{2}{*}{$\Delta[\log \mathrm{EMP}]$} & 0.009 & -0.000 & -0.000 & $-0.004^{*}$ & 0.010 & 0.010 & 0.013 \\
\hline & $(0.014)$ & $(0.003)$ & $(0.002)$ & $(0.002)$ & $(0.016)$ & $(0.019)$ & $\begin{array}{l}(0.009) \\
\end{array}$ \\
\hline \multirow[t]{2}{*}{ Ger. mark } & & & & 0.322 & 0.433 & & \\
\hline & & & & $(0.292)$ & (2.919) & & \\
\hline \multirow{2}{*}{ EUR } & & & & & & 0.221 & -3.943 \\
\hline & & & & & & $(1.990)$ & $(3.949)$ \\
\hline \multirow[t]{2}{*}{ t eur } & & & & & & -0.001 & 0.014 \\
\hline & & & & & & $(0.008)$ & $(0.013)$ \\
\hline \multirow[t]{2}{*}{ Constant } & 0.016 & -0.001 & -0.002 & 0.001 & 0.037 & 0.061 & $0.116^{* *}$ \\
\hline & $(0.016)$ & $(0.002)$ & $(0.002)$ & $(0.005)$ & $(0.036)$ & $(0.063)$ & $(0.049)$ \\
\hline \multirow[t]{2}{*}{ t_Ger. mark } & & & & -0.000 & -0.002 & & \\
\hline & & & & $(0.002)$ & $(0.014)$ & & \\
\hline Observations & 46 & 48 & 48 & 48 & 36 & 48 & 42 \\
\hline R-squared & 0.560 & 0.983 & 0.992 & 0.992 & 0.604 & 0.406 & 0.881 \\
\hline GBP & 0.449 & -0.167 & 0.040 & 0.084 & 1.937 & 1.051 & 1.836 \\
\hline
\end{tabular}

\subsection{Vanuatu (vuv)}

\begin{tabular}{|c|c|c|c|c|c|c|c|}
\hline & (1) & (2) & (3) & (4) & (5) & (6) & (7) \\
\hline & vuv $80-83$ & $84-87$ & $88-91$ & $92-95$ & $96-99$ & $00-03$ & $04-07$ \\
\hline \multirow[t]{2}{*}{ JPY } & -0.222 & -0.109 & $3.527^{*}$ & -0.387 & 0.635 & 0.374 & -1.079 \\
\hline & $(0.191)$ & $(0.701)$ & $(1.981)$ & $(0.851)$ & (1.008) & (1.198) & $(2.118)$ \\
\hline \multirow{2}{*}{ USD } & -0.094 & $0.893^{*}$ & $-2.218^{* * *}$ & 0.779 & -0.344 & -0.427 & 0.911 \\
\hline & $(0.255)$ & $(0.470)$ & $(0.812)$ & $(0.946)$ & $(2.811)$ & $(1.445)$ & $(2.971)$ \\
\hline \multirow[t]{2}{*}{ French franc } & $0.923 * * *$ & $2.572^{*}$ & -0.462 & & & & \\
\hline & $(0.223)$ & $(1.327)$ & $(2.082)$ & & & & \\
\hline \multirow[t]{2}{*}{ t j.jpy } & $0.011^{*}$ & 0.008 & $-0.027^{*}$ & 0.003 & -0.002 & -0.001 & 0.004 \\
\hline & $(0.007)$ & $(0.012)$ & $(0.015)$ & $(0.005)$ & $(0.005)$ & $(0.005)$ & $(0.007)$ \\
\hline \multirow[t]{2}{*}{ t_ usd } & $0.019 * *$ & -0.008 & $0.023^{* * *}$ & -0.000 & 0.005 & 0.003 & -0.002 \\
\hline & $(0.008)$ & $(0.007)$ & $(0.007)$ & $(0.006)$ & $(0.014)$ & $(0.005)$ & $(0.010)$ \\
\hline \multirow[t]{2}{*}{ t_Fr. franc } & $-0.023 * * *$ & $-0.036^{*}$ & 0.009 & & & & \\
\hline & $\begin{array}{l}(0.007) \\
\end{array}$ & $(0.021)$ & $(0.017)$ & & & & \\
\hline \multirow{2}{*}{ Ger. mark } & & & & $2.549^{* * *}$ & -3.045 & & \\
\hline & & & & $(0.822)$ & $(2.197)$ & & \\
\hline \multirow[t]{2}{*}{ t_Ger. mark } & & & & $-0.016^{* * *}$ & 0.015 & & \\
\hline & & & & $(0.005)$ & $(0.011)$ & & \\
\hline \multirow[t]{2}{*}{ EUR } & & & & & & -1.278 & 2.357 \\
\hline & & & & & & \begin{tabular}{|l|}
$(1.434)$ \\
\end{tabular} & $(4.029)$ \\
\hline \multirow[t]{2}{*}{ t_eur } & & & & & & 0.006 & -0.008 \\
\hline & & & & & & \begin{tabular}{|l|}
$(0.006)$ \\
\end{tabular} & $(0.013)$ \\
\hline \multirow[t]{2}{*}{ t2 } & -1.321 & -2.950 & 1.128 & $2.307 * *$ & -3.370 & $2.386^{*}$ & -0.196 \\
\hline & $(1.588)$ & $(3.066)$ & $(1.935)$ & $(0.938)$ & $(2.046)$ & $(1.326)$ & $(1.711)$ \\
\hline \multirow{2}{*}{$\Delta[\log \mathrm{EMP}]$} & -0.000 & 0.026 & $0.140^{* *}$ & $0.107^{* *}$ & -0.008 & $0.097 * *$ & $0.152^{* * *}$ \\
\hline & $(0.003)$ & $\begin{array}{l}(0.054) \\
\end{array}$ & $(0.062)$ & $(0.041)$ & $\begin{array}{l}(0.039) \\
\end{array}$ & \begin{tabular}{|l|}
$(0.036)$ \\
\end{tabular} & $(0.050)$ \\
\hline \multirow[t]{2}{*}{ Constant } & 0.003 & 0.012 & -0.014 & -0.039 ** & 0.066 & $-0.061^{*}$ & 0.003 \\
\hline & $(0.005)$ & $(0.019)$ & $(0.024)$ & $(0.016)$ & $(0.042)$ & \begin{tabular}{|l|}
$(0.035)$ \\
\end{tabular} & $(0.053)$ \\
\hline Observations & 34 & 48 & 48 & 48 & 36 & 44 & 37 \\
\hline R-squared & 0.905 & 0.515 & 0.736 & 0.889 & 0.743 & 0.731 & 0.716 \\
\hline GBP & 0.392 & -2.356 & 0.152 & -1.942 & 3.755 & 2.330 & -1.190 \\
\hline
\end{tabular}




\subsection{Western Samoa tala (wst)}

\begin{tabular}{|c|c|c|c|c|c|c|c|}
\hline & (1) & (2) & (3) & (4) & (5) & (6) & (7) \\
\hline & wst $80-83$ & $84-87$ & $88-91$ & $92-95$ & 96-99 & $00-03$ & 04-07 \\
\hline \multirow[t]{2}{*}{ JPY } & 0.198 & 1.097 & $4.081 * *$ & $-0.867 * *$ & 0.125 & 2.129 & 0.777 \\
\hline & $(0.237)$ & $(0.920)$ & $(1.847)$ & $(0.388)$ & $(1.652)$ & $(1.277)$ & $(2.049)$ \\
\hline \multirow[t]{2}{*}{ USD } & $0.584 * * *$ & -1.411 & -1.532 & $1.762 * * *$ & -0.064 & $-2.972 * *$ & -0.503 \\
\hline & $(0.175)$ & $(1.072)$ & $(1.026)$ & $(0.648)$ & $(2.942)$ & $(1.441)$ & $(2.377)$ \\
\hline \multirow[t]{2}{*}{ French franc } & -0.023 & 1.077 & -4.268 & & & & \\
\hline & $(0.260)$ & $(1.242)$ & $(2.828)$ & & & & \\
\hline \multirow[t]{2}{*}{ t_jpy } & 0.001 & -0.011 & $-0.030 * *$ & $0.006^{* *}$ & 0.000 & -0.008 & -0.002 \\
\hline & $(0.012)$ & $(0.012)$ & $(0.015)$ & $(0.002)$ & $(0.007)$ & $(0.005)$ & $(0.007)$ \\
\hline \multirow[t]{2}{*}{ t_usd } & 0.001 & $0.026^{*}$ & $0.018^{* *}$ & -0.006 & 0.004 & $0.014 * *$ & 0.003 \\
\hline & $(0.010)$ & $(0.014)$ & $(0.008)$ & $(0.004)$ & $(0.014)$ & $(0.005)$ & $(0.008)$ \\
\hline \multirow[t]{2}{*}{ t_Fr. franc } & 0.004 & -0.016 & 0.036 & & & & \\
\hline & $(0.018)$ & $(0.016)$ & $(0.023)$ & & & & \\
\hline \multirow[t]{2}{*}{ Ger. mark } & & & & 1.003 & -3.143 & & \\
\hline & & & & $(0.668)$ & $(2.857)$ & & \\
\hline \multirow[t]{2}{*}{ t_Ger. mark } & & & & -0.006 & 0.016 & & \\
\hline & & & & $(0.004)$ & $(0.014)$ & & \\
\hline \multirow[t]{2}{*}{ EUR } & & & & & & 0.654 & 0.162 \\
\hline & & & & & & $(1.175)$ & $(3.157)$ \\
\hline \multirow[t]{2}{*}{$\mathrm{t}$ _eur } & & & & & & -0.001 & -0.000 \\
\hline & & & & & & $(0.005)$ & $(0.010)$ \\
\hline \multirow[t]{2}{*}{$\mathrm{t} 2$} & -2.156 & $5.195^{*}$ & 1.826 & 0.616 & $-5.839 * *$ & $2.062^{*}$ & 0.516 \\
\hline & $(4.721)$ & $(2.722)$ & $(2.064)$ & $(0.742)$ & $(2.650)$ & $(1.173)$ & $(1.559)$ \\
\hline \multirow[t]{2}{*}{$\Delta[\log \mathrm{EMP}]$} & 0.008 & 0.086 & $0.118^{*}$ & $0.093 * * *$ & 0.092 & $0.156^{* * *}$ & $0.094 * *$ \\
\hline & $(0.007)$ & $(0.072)$ & $(0.069)$ & $(0.024)$ & $(0.076)$ & $(0.035)$ & $(0.036)$ \\
\hline \multirow[t]{2}{*}{ Constant } & -0.006 & $-0.045^{*}$ & -0.026 & -0.010 & $0.118^{* *}$ & $-0.053 *$ & -0.016 \\
\hline & $(0.009)$ & $(0.023)$ & $(0.026)$ & $(0.012)$ & $(0.055)$ & $(0.031)$ & $(0.048)$ \\
\hline Observations & 40 & 48 & 48 & 48 & 36 & 48 & 41 \\
\hline R-squared & 0.576 & 0.522 & 0.786 & 0.954 & 0.782 & 0.826 & 0.751 \\
\hline GBP & 0.241 & 0.238 & 2.719 & -0.898 & 4.083 & 1.189 & 0.564 \\
\hline
\end{tabular}

\subsection{Mexico (mxn)}

\begin{tabular}{|l|l|l|l|l|l|l|l|}
\hline & $(1)$ & $(2)$ & $(3)$ & $(4)$ & $(5)$ & $(6)$ & $(7)$ \\
\hline & mxn 80-83 & $84-87$ & $88-91$ & $92-95$ & $96-99$ & $00-03$ & $04-07$ \\
\hline JPY & 0.606 & 0.896 & $1.013^{*}$ & $-5.586^{* *}$ & 1.865 & 1.575 & -0.740 \\
\hline & $(0.734)$ & $(1.312)$ & $(0.548)$ & $(2.116)$ & $(1.614)$ & $(1.887)$ & $(2.752)$ \\
\hline USD & 0.272 & 0.993 & $0.841^{* * *}$ & $5.408^{*}$ & 6.148 & 2.699 & 0.541 \\
\hline & $(0.573)$ & $(1.012)$ & $(0.278)$ & $(2.703)$ & $(4.247)$ & $(2.095)$ & $(3.784)$ \\
\hline French franc & 0.412 & 0.794 & $-1.248^{* *}$ & & & & \\
\hline & $(0.523)$ & $(1.313)$ & $(0.561)$ & & & & \\
\hline t_jpy & -0.036 & -0.014 & $-0.008^{*}$ & $0.036^{* * *}$ & -0.008 & -0.006 & 0.003 \\
\hline & $(0.056)$ & $(0.019)$ & $(0.004)$ & $(0.013)$ & $(0.007)$ & $(0.007)$ & $(0.009)$ \\
\hline t_usd & 0.048 & 0.002 & 0.001 & -0.030 & -0.025 & -0.007 & 0.000 \\
\hline & $(0.054)$ & $(0.013)$ & $(0.002)$ & $(0.018)$ & $(0.020)$ & $(0.008)$ & $(0.013)$ \\
\hline t_F. franc & -0.030 & -0.014 & $0.010^{* *}$ & & & & \\
\hline & $(0.039)$ & $(0.018)$ & $(0.005)$ & & & & \\
\hline Ger. mark & & & & $16.001^{* * *}$ & $-4.846^{* *}$ & & \\
\hline & & & & $(5.061)$ & $(2.329)$ & & 0.523 \\
\hline EUR & & & & & & $(1.814)$ & $(4.520)$ \\
\hline
\end{tabular}




\begin{tabular}{|c|c|c|c|c|c|c|c|}
\hline \multirow{2}{*}{$t$ _eur } & & & & & & -0.001 & $-0.028^{*}$ \\
\hline & & & & & & $(0.007)$ & $(0.015)$ \\
\hline \multirow{2}{*}{ t_Ger. mark } & & & & $-0.104 * * *$ & $0.023^{*}$ & & \\
\hline & & & & $(0.033)$ & $(0.011)$ & & \\
\hline \multirow[t]{2}{*}{$\mathrm{t} 2$} & -14.909 & $-10.595 * * *$ & 0.984 & -3.209 & -1.391 & 0.036 & 1.007 \\
\hline & $(9.239)$ & $(2.976)$ & $(0.805)$ & (3.802) & $(2.922)$ & $(1.681)$ & $(1.671)$ \\
\hline \multirow[t]{2}{*}{$\Delta[\log \mathrm{EMP}]$} & $0.207^{*}$ & 0.112 & -0.005 & $0.208 * * *$ & $0.346^{* * *}$ & $0.395 * * *$ & $0.360 * * *$ \\
\hline & $(0.122)$ & $(0.068)$ & $(0.004)$ & $(0.060)$ & $(0.084)$ & $(0.104)$ & $(0.083)$ \\
\hline \multirow[t]{2}{*}{ Constant } & -0.003 & 0.026 & $-0.019^{*}$ & 0.046 & 0.017 & -0.008 & -0.032 \\
\hline & $(0.016)$ & $(0.021)$ & $(0.010)$ & $(0.060)$ & $(0.060)$ & $(0.045)$ & $(0.050)$ \\
\hline Observations & 46 & 48 & 48 & 48 & 36 & 48 & 42 \\
\hline R-squared & 0.362 & 0.823 & 0.982 & 0.780 & 0.833 & 0.786 & 0.744 \\
\hline GBP & -0.291 & -1.682 & 0.394 & -14.823 & -2.168 & -3.797 & -7.142 \\
\hline
\end{tabular}

\section{* Statistically significant at $\mathbf{. 1 0}$ level \\ ** Statistically significant at $\mathbf{0 5}$ level $* * *$ Statistically significant at .01 level}




\section{Table 7:}

\section{Extension 2:}

Taking into account the relative variance of reserve changes and exchange rate changes in the computation of Exchange Market Pressure When Estimating the De Facto Exchange Rate Regime

$(01 / 1980-06 / 2007) \quad$ numeraire currency $=$ SDR

7.1 Australian dollar (aud)

\begin{tabular}{|c|c|c|c|c|}
\hline & (1) & (2) & (3) & (4) \\
\hline & aud 92-95 & $96-99$ & $00-03$ & $04-07$ \\
\hline \multirow[t]{2}{*}{ JPY } & 0.060 & $0.171 * * *$ & $0.174 * * *$ & $0.145 * * *$ \\
\hline & $(0.082)$ & $(0.030)$ & $(0.050)$ & $(0.035)$ \\
\hline \multirow[t]{2}{*}{ USD } & $0.868^{* * *}$ & $0.436^{* * *}$ & $0.437 * * *$ & $0.379 * * *$ \\
\hline & $(0.062)$ & $(0.073)$ & $(0.083)$ & $(0.030)$ \\
\hline \multirow{2}{*}{ Germany } & -0.044 & $0.228 * *$ & & \\
\hline & $(0.110)$ & $(0.107)$ & & \\
\hline \multirow[t]{2}{*}{$\Delta[\log \mathrm{EMP}]$} & $0.718 * * *$ & $1.038^{* * *}$ & $0.911 * * *$ & $0.999 * * *$ \\
\hline & $(0.102)$ & $(0.061)$ & $(0.058)$ & $(0.036)$ \\
\hline \multirow[t]{2}{*}{ EUR } & & & $0.374 * * *$ & $0.382 * * *$ \\
\hline & & & $(0.053)$ & $(0.081)$ \\
\hline \multirow[t]{2}{*}{ Constant } & 0.002 & -0.002 & -0.001 & -0.001 \\
\hline & $(0.002)$ & $(0.002)$ & $(0.001)$ & $(0.001)$ \\
\hline Observations & 48 & 36 & 48 & 42 \\
\hline R-squared & 0.891 & 0.907 & 0.923 & 0.951 \\
\hline GBP & 0.116 & 0.166 & 0.014 & 0.093 \\
\hline$\lambda$ & 0.541 & 0.145 & 0.153 & 0.056 \\
\hline
\end{tabular}

Notes:

4. $\lambda=\operatorname{var}(\Delta[\log E x]) / \operatorname{Var}(\Delta[\log \operatorname{Res}])$

5. $\Delta[\log E M P]=\{[\operatorname{var} \Delta[\log E x] /(\operatorname{var} \Delta[\log E x]+\operatorname{Var}(\Delta[\log R e s])\} \cdot \Delta[\log \operatorname{Res}]+\{\operatorname{Var}(\Delta[\log R e s] /$ $(\operatorname{var} \Delta[\log E x]+\operatorname{Var}(\Delta[\log \operatorname{Res}])\} \cdot \Delta[\log E x]$

7.2 Canadian dollar (cad)

\begin{tabular}{|c|c|c|c|c|c|}
\hline & (1) & (2) & (3) & (4) & $(5)$ \\
\hline & cad 90-93 & $94-97$ & 98-01 & $02-05$ & 06-09 \\
\hline \multirow[t]{2}{*}{ JPY } & $0.149 * * *$ & $0.140 * * *$ & 0.105 & $0.295 * * *$ & -0.092 \\
\hline & $(0.021)$ & $(0.027)$ & $(0.050)$ & $(0.081)$ & $(0.209)$ \\
\hline \multirow[t]{2}{*}{ USD } & $0.562 * * *$ & $0.544 * * *$ & $0.394^{*}$ & $0.404 * * *$ & $0.465^{*}$ \\
\hline & $(0.025)$ & $(0.044)$ & $(0.139)$ & $(0.095)$ & $(0.206)$ \\
\hline \multirow[t]{2}{*}{ Germany } & $0.209 * * *$ & $0.221 * * *$ & 0.150 & & \\
\hline & $(0.024)$ & $(0.039)$ & $(0.155)$ & & \\
\hline \multirow[t]{2}{*}{$\Delta[\log \mathrm{EMP}]$} & $0.770 * * *$ & $0.798 * * *$ & $0.628 * * *$ & $0.923 * * *$ & $0.989 * * *$ \\
\hline & $(0.033)$ & $(0.055)$ & $(0.060)$ & $(0.162)$ & $(0.233)$ \\
\hline \multirow[t]{2}{*}{ EUR } & & & & $0.338 * *$ & 0.230 \\
\hline & & & & $(0.151)$ & $(0.343)$ \\
\hline \multirow[t]{2}{*}{ Constant } & -0.001 & -0.001 & -0.004 & 0.003 & -0.005 \\
\hline & $(0.001)$ & $(0.001)$ & $(0.003)$ & $(0.002)$ & $(0.004)$ \\
\hline Observations & 48 & 48 & 8 & 48 & 14 \\
\hline R-squared & 0.994 & 0.963 & 0.939 & 0.785 & 0.828 \\
\hline GBP & 0.080 & 0.096 & 0.351 & -0.037 & 0.397 \\
\hline
\end{tabular}




\begin{tabular}{|l|l|l|l|l|l|}
\hline$\lambda$ & 0.076 & 0.077 & 0.121 & 0.710 & 0.555 \\
\hline
\end{tabular}

\subsection{Chile (clp)}

\begin{tabular}{|l|l|l|l|l|l|l|l|}
\hline & $(1)$ & $(2)$ & $(3)$ & $(4)$ & $(5)$ & $(6)$ & $(7)$ \\
\hline & clp 80-83 & $84-87$ & $88-91$ & $92-95$ & $96-99$ & $00-03$ & $04-07$ \\
\hline JPY & 0.025 & $0.662^{* *}$ & $0.194^{* *}$ & $0.201^{* * *}$ & $0.131^{* * *}$ & 0.130 & 0.094 \\
\hline & $(0.053)$ & $(0.317)$ & $(0.079)$ & $(0.057)$ & $(0.022)$ & $(0.150)$ & $(0.061)$ \\
\hline USD & $0.519^{* * *}$ & $0.752^{* *}$ & $0.518^{* * *}$ & $0.646^{* * *}$ & $0.704^{* * *}$ & $0.520^{* *}$ & $0.480^{* * *}$ \\
\hline & $(0.089)$ & $(0.279)$ & $(0.071)$ & $(0.073)$ & $(0.059)$ & $(0.246)$ & $(0.083)$ \\
\hline French franc & $0.376^{* * *}$ & -0.202 & $0.133^{*}$ & & & & \\
\hline & $(0.085)$ & $(0.466)$ & $(0.069)$ & & & & \\
\hline$\Delta[\operatorname{logEMP}]$ & $0.838^{* * *}$ & $0.910^{*}$ & $0.754^{* * *}$ & $0.778^{* * *}$ & $0.709^{* * *}$ & $0.939^{* * *}$ & $0.909^{* * *}$ \\
\hline & $(0.091)$ & $(0.498)$ & $(0.102)$ & $(0.125)$ & $(0.075)$ & $(0.322)$ & $(0.068)$ \\
\hline German mark & & & & 0.027 & $0.184^{* * *}$ & & \\
\hline & & & & $(0.092)$ & $(0.042)$ & & \\
\hline EUR & & & & & & 0.098 & $0.484^{* * *}$ \\
\hline & & & & & & $(0.132)$ & $(0.107)$ \\
\hline Constant & -0.001 & $-0.017 * *$ & $-0.006^{* * *}$ & $-0.006^{* * *}$ & $-0.002^{* * *}$ & -0.002 & 0.001 \\
\hline & $(0.002)$ & $(0.007)$ & $(0.001)$ & $(0.002)$ & $(0.001)$ & $(0.004)$ & $(0.001)$ \\
\hline Observations & 46 & 48 & 48 & 48 & 36 & 48 & 41 \\
\hline R-squared & 0.922 & 0.708 & 0.952 & 0.906 & 0.962 & 0.487 & 0.927 \\
\hline GBP & 0.080 & -0.212 & 0.156 & 0.126 & -0.019 & 0.252 & -0.058 \\
\hline$\lambda$ & 0.198 & 1.292 & 0.208 & 1.007 & 0.349 & 2.357 & 0.223 \\
\hline
\end{tabular}

\subsection{Chinese yuan (cny)}

\begin{tabular}{|l|l|l|}
\hline & $(1)$ & $(2)$ \\
\hline & cny 01-04 & $05-08$ \\
\hline EUR & 0.074 & 0.079 \\
\hline USD & $(0.069)$ & $(0.081)$ \\
\hline & $0.949^{* * *}$ & $1.058^{* * *}$ \\
\hline JPY & $(0.058)$ & $(0.110)$ \\
\hline & 0.003 & 0.039 \\
\hline$\Delta[\operatorname{logEMP}]$ & $(0.011)$ & $(0.035)$ \\
\hline & 0.136 & $0.209 *$ \\
\hline KRW & $(0.141)$ & $(0.101)$ \\
\hline & & 0.061 \\
\hline SGD & & $(0.052)$ \\
\hline & & -0.164 \\
\hline MYR & & $(0.105)$ \\
\hline & & 0.025 \\
\hline RUB & & $(0.042)$ \\
\hline & & -0.131 \\
\hline AUD & & $(0.147)$ \\
\hline & & 0.027 \\
\hline THB & & $(0.026)$ \\
\hline & & 0.037 \\
\hline CAD & & $(0.048)$ \\
\hline & & -0.052 \\
\hline Constant & -0.001 & $(0.031)$ \\
\hline & $(0.001)$ & 0.000 \\
\hline Observations & 0.987 & $(0.002)$ \\
\hline R-squared & -0.026 & 23 \\
\hline GBP & & 0.995 \\
\hline & & 0.023 \\
\hline
\end{tabular}




\begin{tabular}{|l|l|l|}
\hline$\lambda$ & 0.623 & 1.025 \\
\hline
\end{tabular}

\subsection{Danish krone (dkk)}

\begin{tabular}{|c|c|c|c|c|c|c|c|}
\hline & (1) & (2) & (3) & (4) & $(5)$ & (6) & (7) \\
\hline & dkk 80-83 & $84-87$ & $88-91$ & $92-95$ & $96-99$ & $00-03$ & 04-07 \\
\hline \multirow[t]{2}{*}{ JPY } & $0.065 * *$ & $0.228 * * *$ & $0.120 * * *$ & $0.182 * * *$ & $0.053 * *$ & 0.018 & $0.044 * *$ \\
\hline & $(0.024)$ & $(0.056)$ & $(0.030)$ & $(0.026)$ & $(0.019)$ & $(0.027)$ & $(0.019)$ \\
\hline \multirow[t]{2}{*}{ USD } & $0.619 * * *$ & $0.368 * * *$ & $0.222 * * *$ & $0.343^{* * *}$ & $0.126^{* *}$ & 0.072 & $0.103^{*}$ \\
\hline & $(0.050)$ & $(0.064)$ & $(0.051)$ & $(0.025)$ & $(0.048)$ & $(0.052)$ & $(0.056)$ \\
\hline \multirow[t]{2}{*}{ French franc } & $0.173 * * *$ & $0.317 * * *$ & $0.612 * * *$ & & & & \\
\hline & $(0.055)$ & $(0.112)$ & $(0.080)$ & & & & \\
\hline \multirow[t]{2}{*}{$\Delta[\log \mathrm{EMP}]$} & $1.283 * * *$ & $0.902 * * *$ & $0.608 * * *$ & $0.940 * * *$ & $0.322 * * *$ & 0.164 & $0.313 * *$ \\
\hline & $(0.095)$ & $(0.146)$ & $(0.123)$ & $(0.061)$ & $(0.116)$ & $(0.103)$ & $(0.153)$ \\
\hline \multirow[t]{2}{*}{ German mark } & & & & $0.340 * * *$ & $0.763 * * *$ & & \\
\hline & & & & $(0.047)$ & $(0.079)$ & & \\
\hline \multirow[t]{2}{*}{ EUR } & & & & & & $0.889 * * *$ & $0.749 * * *$ \\
\hline & & & & & & $(0.080)$ & $(0.109)$ \\
\hline \multirow[t]{2}{*}{ Constant } & 0.000 & -0.000 & 0.000 & 0.000 & 0.000 & -0.000 & 0.000 \\
\hline & $(0.001)$ & $(0.001)$ & $(0.001)$ & $(0.000)$ & $(0.000)$ & $(0.000)$ & $(0.000)$ \\
\hline Observations & 46 & 48 & 48 & 48 & 36 & 48 & 41 \\
\hline R-squared & 0.981 & 0.946 & 0.958 & 0.983 & 0.994 & 0.984 & 0.973 \\
\hline GBP & 0.143 & 0.088 & 0.045 & 0.135 & 0.058 & 0.022 & 0.104 \\
\hline$\lambda$ & 0.033 & 0.032 & 0.071 & 0.021 & 0.035 & 0.141 & 0.079 \\
\hline
\end{tabular}

\subsection{Hong Kong dollar (hkd)}

\begin{tabular}{|c|c|c|c|}
\hline & (1) & $(2)$ & (3) \\
\hline & hkd 97-00 & 01-04 & $05-08$ \\
\hline \multirow[t]{2}{*}{ JPY } & 0.004 & -0.004 & -0.006 \\
\hline & $(0.008)$ & $(0.012)$ & $(0.021)$ \\
\hline \multirow[t]{2}{*}{ USD } & $0.975 * * *$ & $1.005 * * *$ & $1.008 * * *$ \\
\hline & $(0.032)$ & $(0.011)$ & $(0.040)$ \\
\hline \multirow[t]{2}{*}{ KRW } & 0.002 & 0.001 & 0.007 \\
\hline & $(0.003)$ & $(0.014)$ & $(0.029)$ \\
\hline \multirow[t]{2}{*}{ SGD } & 0.000 & -0.023 & 0.020 \\
\hline & $(0.009)$ & $(0.023)$ & $(0.049)$ \\
\hline \multirow[t]{2}{*}{ AUD } & 0.004 & -0.001 & 0.023 \\
\hline & $(0.008)$ & $(0.006)$ & $(0.020)$ \\
\hline \multirow[t]{2}{*}{ MYR } & -0.005 & & -0.008 \\
\hline & $(0.005)$ & & $(0.034)$ \\
\hline \multirow[t]{2}{*}{ THB } & -0.000 & 0.018 & -0.025 \\
\hline & $(0.005)$ & $(0.018)$ & $(0.032)$ \\
\hline \multirow[t]{2}{*}{ Germany } & 0.005 & & \\
\hline & $(0.016)$ & & \\
\hline \multirow[t]{2}{*}{$\Delta[\log \mathrm{EMP}]$} & 0.022 & $-0.032 * *$ & -0.017 \\
\hline & $(0.043)$ & $(0.016)$ & $(0.034)$ \\
\hline \multirow[t]{2}{*}{ EUR } & & -0.005 & -0.002 \\
\hline & & $(0.010)$ & $(0.034)$ \\
\hline \multirow{2}{*}{ Constant } & -0.000 & -0.000 & -0.000 \\
\hline & $(0.000)$ & $(0.000)$ & $(0.000)$ \\
\hline Observations & 23 & 48 & 30 \\
\hline R-squared & 0.998 & 0.997 & 0.997 \\
\hline GBP & 0.015 & 0.009 & -0.016 \\
\hline$\lambda$ & 0.111 & 0.689 & 0.941 \\
\hline
\end{tabular}




\subsection{Malaysian ringgit (myr)}

\begin{tabular}{|l|l|l|l|l|}
\hline & $(1)$ & $(2)$ & $(3)$ & $(4)$ \\
\hline & myr 92-95 & $96-99$ & $00-03$ & $04-07$ \\
\hline JPY & $0.156^{* *}$ & -0.171 & -0.000 & 0.021 \\
\hline & $(0.077)$ & $(0.166)$ & $(0.000)$ & $(0.047)$ \\
\hline USD & 0.085 & 0.028 & $1.000^{* * *}$ & $0.490^{* * *}$ \\
\hline & $(0.732)$ & $(0.306)$ & $0.000)$ & $(0.079)$ \\
\hline KRW & 0.133 & -0.077 & 0.000 & -0.057 \\
\hline SGD & $(0.145)$ & $(0.068)$ & $(0.000)$ & $(0.055)$ \\
\hline & 0.039 & $1.243^{*}$ & -0.000 & $0.299^{* * *}$ \\
\hline AUD & $(0.151)$ & $(0.609)$ & $(0.000)$ & $(0.105)$ \\
\hline & -0.039 & -0.072 & 0.000 & -0.004 \\
\hline THB & $(0.048)$ & $(0.201)$ & $0.000)$ & $(0.038)$ \\
\hline & 0.253 & 0.246 & 0.000 & 0.016 \\
\hline German mark & $0.842)$ & $(0.227)$ & $(0.000)$ & $(0.053)$ \\
\hline & $0.218^{* * *}$ & -0.140 & & \\
\hline$\Delta[$ logEMP $]$ & $(0.070)$ & $0.247)$ & & $0.588^{* * *}$ \\
\hline & $0.958^{* * *}$ & 0.305 & -0.000 & $(0.126)$ \\
\hline EUR & $(0.071)$ & $(0.236)$ & $(0.000)$ & $0.167^{* *}$ \\
\hline & & & -0.000 & $(0.078)$ \\
\hline Constant & -0.000 & & $(0.000)$ & -0.001 \\
\hline & $(0.001)$ & -0.005 & -0.000 & $(0.001)$ \\
\hline Observations & 48 & $(0.005)$ & $0.000)$ & 40 \\
\hline R-squared & 0.981 & 36 & 48 & 0.969 \\
\hline GBP & 0.155 & 0.837 & 1.000 & 0.068 \\
\hline$\lambda$ & 0.062 & -0.059 & 0.000 & 0.254 \\
\hline
\end{tabular}

\subsection{Panama (pab)}

\begin{tabular}{|c|c|c|c|c|c|c|c|}
\hline & $(1)$ & (2) & (3) & (4) & $(5)$ & (6) & $(7)$ \\
\hline & pab 80-83 & $84-87$ & $88-91$ & $92-95$ & $96-99$ & $00-03$ & 04-07 \\
\hline \multirow[t]{2}{*}{ JPY } & 0.001 & 0.000 & -0.002 & $0.006^{*}$ & 0.005 & $0.013 * * *$ & 0.000 \\
\hline & $(0.002)$ & $(0.003)$ & $(0.003)$ & $(0.003)$ & $(0.003)$ & $(0.003)$ & $(0.004)$ \\
\hline \multirow[t]{2}{*}{ USD } & $0.988^{* * *}$ & $1.005^{* * *}$ & $0.997 * * *$ & $0.987 * * *$ & $0.982 * * *$ & $0.961 * * *$ & $0.998^{* * *}$ \\
\hline & $(0.007)$ & $(0.007)$ & $(0.010)$ & $(0.007)$ & $(0.013)$ & $(0.010)$ & $(0.017)$ \\
\hline \multirow{2}{*}{ French franc } & 0.006 & -0.006 & 0.002 & & & & \\
\hline & $(0.004)$ & $(0.004)$ & $(0.005)$ & & & & \\
\hline \multirow[t]{2}{*}{$\Delta[\log \mathrm{EMP}]$} & $0.026^{*}$ & -0.006 & 0.006 & $0.023 * *$ & 0.034 & $0.062 * * *$ & 0.006 \\
\hline & $(0.013)$ & $(0.012)$ & $(0.015)$ & $(0.011)$ & $(0.023)$ & $(0.015)$ & $(0.027)$ \\
\hline \multirow[t]{2}{*}{ German mark } & & & & 0.005 & $0.013 *$ & & \\
\hline & & & & $(0.004)$ & $(0.007)$ & & \\
\hline \multirow[t]{2}{*}{ EUR } & & & & & & $0.017 * * *$ & 0.006 \\
\hline & & & & & & $(0.005)$ & $(0.011)$ \\
\hline \multirow[t]{2}{*}{ Constant } & 0.000 & 0.000 & 0.000 & -0.000 & 0.000 & 0.000 & 0.000 \\
\hline & $(0.000)$ & $(0.000)$ & $(0.000)$ & $(0.000)$ & $(0.000)$ & $(0.000)$ & $(0.000)$ \\
\hline Observations & 46 & 48 & 48 & 48 & 36 & 48 & 37 \\
\hline R-squared & 1.000 & 1.000 & 1.000 & 1.000 & 1.000 & 1.000 & 1.000 \\
\hline GBP & 0.005 & 0.001 & 0.003 & 0.003 & 0.001 & 0.009 & -0.004 \\
\hline$\lambda$ & 0.002 & 0.004 & 0.016 & 0.038 & 0.008 & 0.015 & 0.004 \\
\hline
\end{tabular}

* Statistically significant at $\mathbf{. 1 0}$ level ** Statistically significant at .05 level 
Table 8: Extension 3

Entering the change in the interest rate alongside the change in reserves and the change in the exchange rate in the definition of Exchange Market Pressure when Estimating the De Facto Exchange Rate Regime

$(01 / 1980-06 / 2007) \quad$ numeraire currency $=$ SDR

8.1 Australian dollar (aud)

\begin{tabular}{|l|l|l|l|l|}
\hline & aud 92-95 & $96-99$ & $00-03$ & $04-07$ \\
\hline JPY & 0.062 & $0.170^{* * *}$ & $0.143^{* * *}$ & $0.149^{* * *}$ \\
\hline & $(0.083)$ & $(0.029)$ & $(0.048)$ & $(0.032)$ \\
\hline USD & $0.866^{* * *}$ & $0.445^{* * *}$ & $0.466^{* * *}$ & $0.370^{* * *}$ \\
\hline & $(0.061)$ & $(0.082)$ & $(0.092)$ & $(0.040)$ \\
\hline Germany & -0.047 & $0.249^{* *}$ & & \\
\hline & $(0.109)$ & $(0.110)$ & & \\
\hline & $0.472^{* * *}$ & $0.933^{* * *}$ & $0.774^{* * *}$ & $0.909^{* * *}$ \\
\hline EUR & $(0.064)$ & $(0.060)$ & $(0.043)$ & $(0.039)$ \\
\hline & & & $0.364^{* * *}$ & $0.394^{* * *}$ \\
\hline Constant & & & $(0.048)$ & $(0.069)$ \\
\hline & 0.002 & -0.001 & -0.001 & $-0.001^{*}$ \\
\hline Observations & $(0.002)$ & $(0.002)$ & $(0.001)$ & $(0.001)$ \\
\hline R-squared & 48 & 36 & 48 & 42 \\
\hline GBP & 0.894 & 0.904 & 0.922 & 0.939 \\
\hline$\lambda$ & 0.119 & 0.137 & 0.027 & 0.088 \\
\hline$\gamma$ & 0.541 & 0.145 & 0.153 & 0.056 \\
\hline
\end{tabular}

Notes:

1. $\lambda=\operatorname{var}(\Delta[\log E x]) / \operatorname{Var}(\Delta[\log \operatorname{Res}])$

2. $\gamma=\operatorname{var}(\Delta[\log E x]) / \operatorname{Var}(\Delta[i])$

3. $\Delta[\log E M P]=\{\operatorname{var}(\Delta[\log E x]) / \operatorname{Var}(\Delta[\log \operatorname{Res}])\} \cdot \Delta[\log \operatorname{Res}]+\{\operatorname{var}(\Delta[\log E x]) / \operatorname{Var}(\Delta i)\} \cdot \Delta$

$i+\Delta[\log E x]$

that is,

$\Delta[\log E M P]=\lambda \cdot \Delta[\log R e s]+\gamma \cdot \Delta i+\Delta[\log E x]$ 


\subsection{Canadian dollar (cad)}

\begin{tabular}{|l|l|l|l|l|l|}
\hline & $(1)$ & $(2)$ & $(3)$ & $(4)$ & $(5)$ \\
\hline & cad 90-93 & $94-97$ & $98-01$ & $02-05$ & $06-09$ \\
\hline & $0.154^{* *}$ & $0.142^{* * *}$ & 0.112 & $0.291^{* * *}$ & -0.099 \\
\hline USY & $(0.022)$ & $(0.027)$ & $(0.053)$ & $(0.080)$ & $(0.209)$ \\
\hline & $0.552^{* * *}$ & $0.541^{* * *}$ & $0.375^{*}$ & $0.421^{* * *}$ & $0.466^{* *}$ \\
\hline Germany & $(0.025)$ & $(0.045)$ & $(0.142)$ & $(0.090)$ & $(0.199)$ \\
\hline & $0.206^{* * *}$ & $0.220^{* * *}$ & 0.165 & & \\
\hline$\Delta[\operatorname{logEMP}]$ & $(0.026)$ & $(0.039)$ & $(0.155)$ & & $0.521^{* * *}$ \\
\hline & $0.729 * * *$ & $0.753^{* * *}$ & $0.588^{* * *}$ & $0.637^{* * *}$ \\
\hline EUR & $(0.032)$ & $(0.051)$ & $(0.051)$ & $(0.086)$ & $(0.149)$ \\
\hline & & & & $0.303^{*}$ & 0.242 \\
\hline Constant & & & & $(0.151)$ & $(0.336)$ \\
\hline & -0.000 & -0.001 & -0.004 & 0.003 & -0.005 \\
\hline Observations & $(0.001)$ & $(0.001)$ & $(0.003)$ & $(0.002)$ & $(0.004)$ \\
\hline R-squared & 47 & 48 & 8 & 48 & 14 \\
\hline GBP & 0.994 & 0.962 & 0.937 & 0.792 & 0.829 \\
\hline$\lambda$ & 0.088 & 0.097 & 0.347 & -0.014 & 0.391 \\
\hline$\gamma$ & 0.076 & 0.077 & 0.121 & 0.710 & 0.555 \\
\hline
\end{tabular}

\subsection{Chinese yuan (cny)}

\begin{tabular}{|c|c|c|}
\hline & $(1)$ & $(2)$ \\
\hline & Cny 01-04 & $05-08$ \\
\hline \multirow[t]{2}{*}{ EUR } & 0.071 & 0.078 \\
\hline & $(0.067)$ & $(0.079)$ \\
\hline \multirow[t]{2}{*}{ USD } & $0.956 * * *$ & $1.040^{* * *}$ \\
\hline & $(0.051)$ & $(0.113)$ \\
\hline \multirow[t]{2}{*}{ JPY } & 0.000 & 0.039 \\
\hline & $(0.009)$ & $(0.034)$ \\
\hline \multirow[t]{2}{*}{$\Delta[\log E M P]$} & 0.078 & $0.105^{*}$ \\
\hline & $(0.080)$ & $(0.050)$ \\
\hline \multirow[t]{2}{*}{ KRW } & & 0.062 \\
\hline & & $(0.053)$ \\
\hline \multirow[t]{2}{*}{ SGD } & & -0.162 \\
\hline & & $(0.104)$ \\
\hline \multirow[t]{2}{*}{ MYR } & & 0.040 \\
\hline & & $(0.054)$ \\
\hline \multirow[t]{2}{*}{ RUB } & & -0.123 \\
\hline & & $(0.145)$ \\
\hline \multirow[t]{2}{*}{ AUD } & & 0.021 \\
\hline & & $(0.026)$ \\
\hline \multirow[t]{2}{*}{ THB } & & 0.034 \\
\hline & & $(0.045)$ \\
\hline \multirow[t]{2}{*}{ CAD } & & -0.052 \\
\hline & & $(0.031)$ \\
\hline \multirow[t]{2}{*}{ Constant } & -0.001 & 0.000 \\
\hline & $(0.001)$ & $(0.002)$ \\
\hline Observations & 48 & 22 \\
\hline R-squared & 0.987 & 0.995 \\
\hline GBP & -0.027 & 0.022 \\
\hline$\lambda$ & 0.623 & 1.025 \\
\hline$\gamma$ & 0.028 & 0.011 \\
\hline
\end{tabular}




\subsection{Hong Kong dollar (hkd)}

\begin{tabular}{|c|c|c|c|}
\hline & (1) & (2) & (3) \\
\hline & hkd 97-00 & 01-04 & $05-08$ \\
\hline \multirow[t]{2}{*}{ JPY } & 0.004 & -0.005 & -0.006 \\
\hline & $(0.008)$ & $(0.011)$ & $(0.022)$ \\
\hline \multirow[t]{2}{*}{ USD } & $0.975 * * *$ & $1.007 * * *$ & $1.006 * * *$ \\
\hline & $(0.032)$ & $(0.010)$ & $(0.040)$ \\
\hline \multirow[t]{2}{*}{ KRW } & 0.002 & 0.002 & 0.006 \\
\hline & $(0.003)$ & $(0.014)$ & $(0.029)$ \\
\hline \multirow[t]{2}{*}{ SGD } & -0.000 & -0.022 & 0.020 \\
\hline & $(0.009)$ & $(0.023)$ & $(0.049)$ \\
\hline \multirow[t]{2}{*}{ AUD } & 0.004 & -0.001 & 0.023 \\
\hline & $(0.008)$ & $(0.006)$ & $(0.020)$ \\
\hline \multirow[t]{2}{*}{ MYR } & -0.005 & & -0.007 \\
\hline & $(0.005)$ & & $(0.034)$ \\
\hline \multirow[t]{2}{*}{ THB } & -0.000 & 0.018 & -0.025 \\
\hline & $(0.005)$ & $(0.018)$ & $(0.032)$ \\
\hline \multirow{2}{*}{ Germany } & 0.005 & & \\
\hline & $(0.016)$ & & \\
\hline \multirow[t]{2}{*}{$\Delta[\log \mathrm{EMP}]$} & 0.023 & $-0.034 * *$ & -0.014 \\
\hline & $(0.042)$ & $(0.016)$ & $(0.035)$ \\
\hline \multirow[t]{2}{*}{ EUR } & & -0.006 & -0.001 \\
\hline & & $(0.010)$ & $(0.034)$ \\
\hline \multirow[t]{2}{*}{ Constant } & -0.000 & -0.000 & -0.000 \\
\hline & $(0.000)$ & $(0.000)$ & $(0.000)$ \\
\hline Observations & 23 & 48 & 30 \\
\hline R-squared & 0.999 & 0.997 & 0.997 \\
\hline GBP & 0.015 & 0.008 & -0.015 \\
\hline$\lambda$ & 0.111 & 0.689 & 0.941 \\
\hline$\gamma$ & 0.000 & 0.002 & 0.001 \\
\hline
\end{tabular}

\subsection{Norway (nok)}

\begin{tabular}{|c|c|c|c|c|c|c|c|}
\hline & (1) & (2) & (3) & (4) & (5) & (6) & (7) \\
\hline & nok $80-83$ & $84-87$ & $88-91$ & $92-95$ & $96-99$ & $00-03$ & 04-07 \\
\hline \multirow[t]{2}{*}{ JPY } & $0.091 * * *$ & $0.190 * * *$ & $0.124 * * *$ & $0.146^{* * *}$ & $0.128 * * *$ & $0.193 * * *$ & $0.169 * *$ \\
\hline & $(0.026)$ & $(0.050)$ & $(0.035)$ & $(0.030)$ & $(0.022)$ & $(0.055)$ & $(0.070)$ \\
\hline \multirow[t]{2}{*}{ USD } & $0.500 * * *$ & $0.282 * * *$ & $0.305 * * *$ & $0.317 * * *$ & $0.388 * * *$ & $0.298 * * *$ & $0.211^{* * *}$ \\
\hline & $(0.045)$ & $(0.046)$ & $(0.025)$ & $(0.040)$ & $(0.034)$ & $(0.058)$ & $(0.067)$ \\
\hline \multirow[t]{2}{*}{ French } & $0.315^{* * *}$ & $0.444 * * *$ & $0.411 * * *$ & & & & \\
\hline & $(0.056)$ & $(0.063)$ & $(0.042)$ & & & & \\
\hline \multirow[t]{2}{*}{$\Delta[\log \mathrm{EMP}]$} & $0.994 * * *$ & $0.679 * * *$ & $0.690 * * *$ & $0.750 * * *$ & $0.827 * * *$ & $0.782 * * *$ & $0.754 * * *$ \\
\hline & $(0.046)$ & $(0.114)$ & $(0.077)$ & $(0.085)$ & $(0.062)$ & $(0.054)$ & $(0.058)$ \\
\hline \multirow[t]{2}{*}{ Germany } & & & & $0.415 * * *$ & $0.400 * * *$ & & \\
\hline & & & & $(0.050)$ & $(0.036)$ & & \\
\hline \multirow[t]{2}{*}{ EUR } & & & & & & $0.358 * * *$ & $0.556 * * *$ \\
\hline & & & & & & $(0.064)$ & $(0.104)$ \\
\hline \multirow[t]{2}{*}{ Constant } & 0.000 & $-0.002 * *$ & 0.000 & -0.001 & -0.000 & -0.000 & -0.002 \\
\hline & $(0.001)$ & $(0.001)$ & $(0.001)$ & $(0.001)$ & $(0.001)$ & $(0.001)$ & $(0.001)$ \\
\hline Observations & 46 & 48 & 48 & 48 & 36 & 48 & 42 \\
\hline R-squared & 0.959 & 0.919 & 0.947 & 0.959 & 0.977 & 0.896 & 0.885 \\
\hline GBP & 0.094 & 0.085 & 0.160 & 0.122 & 0.084 & 0.151 & 0.064 \\
\hline$\lambda$ & 0.032 & 0.140 & 0.108 & 0.075 & 0.061 & 0.149 & 0.175 \\
\hline$\gamma$ & 0.000 & 0.002 & 0.001 & 0.000 & 0.001 & 0.006 & 0.024 \\
\hline
\end{tabular}

* Statistically significant at .10 level

** Statistically significant at $\mathbf{0 5}$ level $* * *$ Statistically significant at .01 level 
Table 9: Extension 4

Check for robustness with respect to the numeraire used to define currency

$(01 / 1980-06 / 2007)$

(numeraire currency $=$ Swiss Franc)

\begin{tabular}{|c|c|c|c|c|}
\hline \multicolumn{5}{|c|}{ 9.1 Australian dollar (aud) } \\
\hline In swissf & (1) & (2) & (3) & (4) \\
\hline & aud $92-95$ & $96-99$ & $00-03$ & $04-07$ \\
\hline \multirow[t]{2}{*}{ JPY } & -0.066 & 0.201 & $0.200^{*}$ & 0.172 \\
\hline & $(0.103)$ & $(0.133)$ & $\begin{array}{l}(0.104) \\
\end{array}$ & $(0.151)$ \\
\hline \multirow[t]{2}{*}{ USD } & $0.825^{* * *}$ & $0.604 * *$ & 0.168 & 0.118 \\
\hline & $(0.111)$ & $(0.245)$ & $(0.187)$ & $(0.142)$ \\
\hline \multirow[t]{2}{*}{ Germany } & 0.106 & -0.012 & & \\
\hline & $\begin{array}{l}(0.190) \\
\end{array}$ & $(0.234)$ & & \\
\hline \multirow[t]{2}{*}{$\Delta\left[\log \operatorname{Res}^{2}+\log \mathrm{Ex}\right]$} & $0.203^{* * *}$ & 0.076 & $0.180^{* * *}$ & 0.055 \\
\hline & $(0.046)$ & $(0.071)$ & $(0.041)$ & $(0.039)$ \\
\hline \multirow[t]{2}{*}{ EUR } & & & $0.778^{* * *}$ & 0.173 \\
\hline & & & $(0.129)$ & $(0.258)$ \\
\hline \multirow[t]{2}{*}{ Constant } & 0.003 & -0.006 & -0.001 & 0.001 \\
\hline & $\begin{array}{l}(0.003) \\
\end{array}$ & $(0.005)$ & $(0.003)$ & $(0.003)$ \\
\hline Observations & 48 & 36 & 48 & 42 \\
\hline R-squared & 0.809 & 0.340 & 0.582 & 0.186 \\
\hline GBP & 0.136 & 0.207 & -0.146 & 0.537 \\
\hline
\end{tabular}

9.2 Botswana pula (bwp)

\begin{tabular}{|c|c|c|c|c|c|c|c|}
\hline In swissf & $(1)$ & (2) & (3) & (4) & (5) & (6) & $(7)$ \\
\hline & bwp 80-83 & $84-87$ & $88-91$ & $92-95$ & $96-99$ & $00-03$ & $04-07$ \\
\hline \multirow[t]{2}{*}{ JPY } & $0.366^{* *}$ & $0.486 * *$ & -0.031 & -0.036 & 0.107 & 0.112 & $0.320^{*}$ \\
\hline & $(0.147)$ & $(0.217)$ & $(0.103)$ & $(0.039)$ & $(0.068)$ & $(0.083)$ & $(0.172)$ \\
\hline \multirow[t]{2}{*}{ USD } & $0.672 * * *$ & 0.004 & $0.286^{* * *}$ & $0.497 * * *$ & -0.260 & -0.008 & $-0.755 * * *$ \\
\hline & $(0.091)$ & $(0.283)$ & $(0.064)$ & $(0.066)$ & $(0.276)$ & $(0.149)$ & $(0.235)$ \\
\hline \multirow[t]{2}{*}{ French } & -0.010 & $0.626^{*}$ & $0.711^{* * *}$ & & & & \\
\hline & $(0.176)$ & $(0.355)$ & $(0.177)$ & & & & \\
\hline \multirow[t]{2}{*}{$\Delta[\log \operatorname{Res}+\log \mathrm{Ex}]$} & -0.025 & 0.017 & $0.244 * * *$ & $0.113 * * *$ & $0.457 * * *$ & $0.488 * * *$ & $0.626 * * *$ \\
\hline & $(0.055)$ & $(0.032)$ & $(0.061)$ & $(0.035)$ & $(0.084)$ & $(0.051)$ & $(0.106)$ \\
\hline \multirow[t]{2}{*}{ Germany } & & & & $0.422 * * *$ & $1.134 * * *$ & & \\
\hline & & & & $(0.108)$ & $(0.282)$ & & \\
\hline \multirow[t]{2}{*}{ EUR } & & & & & & $0.896^{* * *}$ & $1.312^{* * *}$ \\
\hline & & & & & & $(0.128)$ & $(0.245)$ \\
\hline \multirow[t]{2}{*}{ Constant } & $-0.009 *$ & $-0.018 * *$ & $-0.009 * * *$ & $-0.005 * * *$ & $-0.009 * * *$ & 0.003 & $-0.011 * * *$ \\
\hline & $(0.005)$ & $(0.007)$ & $(0.002)$ & $(0.001)$ & $(0.003)$ & $(0.003)$ & $(0.004)$ \\
\hline Observations & 46 & 48 & 48 & 48 & 36 & 48 & 37 \\
\hline R-squared & 0.656 & 0.267 & 0.739 & 0.879 & 0.732 & 0.705 & 0.741 \\
\hline GBP & -0.027 & -0.115 & 0.033 & 0.116 & 0.020 & -0.000 & 0.123 \\
\hline
\end{tabular}

9.3 Canadian dollar (cad)

\begin{tabular}{|l|l|l|l|l|l|}
\hline In swissf & $(1)$ & $(2)$ & $(3)$ & $(4)$ & $(5)$ \\
\hline & cad 90-93 & $94-97$ & $98-01$ & $02-05$ & $06-09$ \\
\hline JPY & 0.040 & 0.003 & 0.012 & $0.338^{* * *}$ & -0.067 \\
\hline & $(0.058)$ & $(0.081)$ & $(0.073)$ & $(0.092)$ & $(0.321)$ \\
\hline USD & $0.800^{* * *}$ & $0.921^{* * *}$ & 0.253 & 0.192 & 0.130 \\
\hline & $(0.055)$ & $(0.110)$ & $(0.320)$ & $(0.138)$ & $(0.316)$ \\
\hline Germany & $0.119^{*}$ & 0.106 & 0.305 & & \\
\hline
\end{tabular}




\begin{tabular}{|l|l|l|l|l|l|}
\hline$\Delta[\operatorname{logRes}+\log \mathrm{Ex}]$ & $0.102 * * *$ & $0.053^{* *}$ & $0.114 * *$ & $0.285^{* * *}$ & $0.331^{* *}$ \\
\hline & $(0.012)$ & $(0.021)$ & $(0.028)$ & $(0.085)$ & $(0.122)$ \\
\hline EUR & & & & $0.644 * * *$ & 0.536 \\
\hline & & & & $(0.224)$ & $(0.568)$ \\
\hline Constant & $-0.003 * *$ & -0.001 & -0.009 & 0.003 & -0.006 \\
\hline & $(0.001)$ & $(0.002)$ & $(0.006)$ & $(0.002)$ & $(0.005)$ \\
\hline Observations & 48 & 48 & 8 & 48 & 14 \\
\hline GBP & 0.960 & 0.778 & 0.787 & 0.699 & 0.605 \\
\hline
\end{tabular}

\subsection{Chile (clp)}

\begin{tabular}{|c|c|c|c|c|c|c|c|}
\hline In swissf & (1) & (2) & (3) & (4) & (5) & (6) & (7) \\
\hline & $\operatorname{clp} 80-83$ & $84-87$ & $88-91$ & $92-95$ & $96-99$ & $00-03$ & 04-07 \\
\hline \multirow[t]{2}{*}{ JPY } & -0.096 & $0.804 * * *$ & 0.025 & $0.159 * *$ & $0.081 * *$ & 0.002 & 0.007 \\
\hline & $(0.082)$ & $(0.296)$ & $(0.122)$ & $(0.076)$ & $(0.032)$ & $(0.085)$ & $(0.130)$ \\
\hline \multirow[t]{2}{*}{ USD } & $0.530 *$ & 0.039 & $0.978^{* * *}$ & $0.463 * * *$ & $0.696 * * *$ & 0.035 & $0.496 * * *$ \\
\hline & $(0.282)$ & $(0.450)$ & $(0.137)$ & $(0.118)$ & $(0.085)$ & $(0.181)$ & $(0.169)$ \\
\hline \multirow[t]{2}{*}{ French } & 0.568 & 0.235 & $-0.239 * *$ & & & & \\
\hline & $(0.343)$ & $(0.475)$ & $(0.114)$ & & & & \\
\hline \multirow[t]{2}{*}{$\Delta[\log R e s+\log E x]$} & $0.155^{* *}$ & $0.482 * *$ & 0.014 & $0.257 * * *$ & $0.220 * * *$ & $0.561 * * *$ & $0.216^{* * *}$ \\
\hline & $(0.072)$ & $(0.195)$ & $(0.051)$ & $(0.064)$ & $(0.030)$ & $(0.062)$ & $(0.050)$ \\
\hline \multirow[t]{2}{*}{ Germany } & & & & $0.322 * *$ & $0.466 * * *$ & & \\
\hline & & & & $(0.155)$ & $(0.074)$ & & \\
\hline \multirow[t]{2}{*}{ EUR } & & & & & & $0.887 * * *$ & $0.810^{* * *}$ \\
\hline & & & & & & $(0.134)$ & $(0.257)$ \\
\hline \multirow[t]{2}{*}{ Constant } & -0.004 & $-0.017 * *$ & $-0.009 * * *$ & $-0.004^{*}$ & $-0.003 * * *$ & -0.000 & 0.002 \\
\hline & $(0.004)$ & $(0.006)$ & $(0.002)$ & $(0.002)$ & $(0.001)$ & $(0.002)$ & $(0.003)$ \\
\hline Observations & 46 & 48 & 48 & 48 & 36 & 48 & 41 \\
\hline R-squared & 0.669 & 0.781 & 0.884 & 0.876 & 0.926 & 0.808 & 0.708 \\
\hline GBP & -0.003 & -0.078 & 0.236 & 0.057 & -0.244 & 0.076 & -0.314 \\
\hline
\end{tabular}

\subsection{Chinese yuan (cny)}

\begin{tabular}{|l|l|l|}
\hline In swissf & $(1)$ & $(2)$ \\
\hline & cny 01-04 & $05-08$ \\
\hline EUR & 0.060 & $0.186^{*}$ \\
\hline & $(0.059)$ & $(0.087)$ \\
\hline USD & $0.993^{* * *}$ & $1.031^{* * *}$ \\
\hline & $(0.018)$ & $(0.097)$ \\
\hline JPY & -0.009 & 0.039 \\
\hline$\Delta[\operatorname{logRes}+\operatorname{logEx}]$ & $(0.011)$ & $(0.030)$ \\
\hline & 0.016 & $0.082^{* *}$ \\
\hline KRW & $(0.017)$ & $(0.030)$ \\
\hline & & 0.049 \\
\hline SGD & & $(0.047)$ \\
\hline & & -0.160 \\
\hline MYR & & $(0.092)$ \\
\hline & & -0.015 \\
\hline RUB & & $(0.039)$ \\
\hline & & -0.174 \\
\hline AUD & & $(0.140)$ \\
\hline & & 0.027 \\
\hline THB & & $(0.024)$ \\
\hline & & 0.046 \\
\hline CAD & & $(0.040)$ \\
\hline & & -0.045 \\
\hline Constant & & $(0.028)$ \\
\hline & & 0.001 \\
\hline & & \\
\hline & & \\
\hline & & \\
\hline & & \\
\hline & & \\
\hline & & \\
\hline & & \\
\hline
\end{tabular}




\begin{tabular}{|l|l|l|}
\hline & $(0.000)$ & $(0.001)$ \\
\hline Observations & 48 & 23 \\
\hline R-squared & 0.986 & 0.996 \\
\hline GBP & -0.043 & 0.017 \\
\hline
\end{tabular}

9.6 Danish krone (dkk)

\begin{tabular}{|c|c|c|c|c|c|c|c|}
\hline In swissf & (1) & $(2)$ & (3) & (4) & $(5)$ & (6) & (7) \\
\hline & dkk 80-83 & $84-87$ & $88-91$ & $92-95$ & 96-99 & 00-03 & 04-07 \\
\hline \multirow[t]{2}{*}{ JPY } & 0.078 & 0.108 & -0.024 & -0.001 & 0.003 & -0.005 & 0.007 \\
\hline & $(0.060)$ & $(0.084)$ & $(0.051)$ & $(0.036)$ & $(0.008)$ & $(0.021)$ & $(0.017)$ \\
\hline \multirow[t]{2}{*}{ USD } & 0.084 & -0.065 & 0.046 & 0.017 & 0.004 & -0.001 & -0.017 \\
\hline & $(0.089)$ & $(0.047)$ & $(0.032)$ & $(0.038)$ & $(0.016)$ & $(0.016)$ & $(0.016)$ \\
\hline \multirow[t]{2}{*}{ French } & $0.821 * * *$ & $0.860 * * *$ & $0.997 * * *$ & & & & \\
\hline & $(0.122)$ & $(0.104)$ & $(0.048)$ & & & & \\
\hline \multirow[t]{2}{*}{$\Delta[\log \operatorname{Res}+\log \mathrm{Ex}]$} & -0.026 & 0.006 & 0.009 & 0.021 & 0.004 & 0.001 & -0.004 \\
\hline & $(0.020)$ & $(0.010)$ & $(0.009)$ & $(0.020)$ & $(0.005)$ & $(0.006)$ & $(0.006)$ \\
\hline \multirow[t]{2}{*}{ Germany } & & & & $0.900 * * *$ & $0.971 * * *$ & & \\
\hline & & & & $(0.080)$ & $(0.019)$ & & \\
\hline \multirow[t]{2}{*}{ EUR } & & & & & & $1.001 * * *$ & $0.939 * * *$ \\
\hline & & & & & & $(0.017)$ & $(0.055)$ \\
\hline \multirow[t]{2}{*}{ Constant } & 0.000 & 0.000 & 0.000 & 0.001 & 0.000 & -0.000 & 0.000 \\
\hline & $(0.002)$ & $(0.001)$ & $(0.001)$ & $(0.001)$ & $(0.000)$ & $(0.000)$ & $(0.000)$ \\
\hline Observations & 46 & 48 & 48 & 48 & 36 & 48 & 41 \\
\hline R-squared & 0.857 & 0.855 & 0.916 & 0.837 & 0.991 & 0.981 & 0.965 \\
\hline GBP & 0.018 & 0.097 & -0.019 & 0.084 & 0.022 & 0.004 & 0.071 \\
\hline
\end{tabular}

\subsection{Fiji dollar}

\begin{tabular}{|l|l|l|l|l|l|l|l|}
\hline In swissf & $(1)$ & $(2)$ & $(3)$ & $(4)$ & $(5)$ & $(6)$ & $(7)$ \\
\hline & fiji $80-83$ & $84-87$ & $88-91$ & $92-95$ & $96-99$ & $00-03$ & $04-07$ \\
\hline JPY & $0.152^{* * *}$ & 0.127 & -0.082 & -0.201 & 0.065 & 0.080 & 0.008 \\
\hline & $(0.030)$ & $(0.153)$ & $(0.091)$ & $(0.147)$ & $(0.107)$ & $(0.052)$ & $(0.054)$ \\
\hline USD & $0.354^{* * *}$ & $1.075^{*}$ & $-1.525^{* * *}$ & $-2.540^{* *}$ & 0.210 & $0.201^{* * *}$ & 0.308 \\
\hline & $(0.105)$ & $(0.536)$ & $(0.556)$ & $(1.168)$ & $(0.225)$ & $(0.065)$ & $(0.200)$ \\
\hline KRW & $-0.152^{*}$ & $-0.921^{*}$ & 0.055 & $0.820^{* *}$ & -0.031 & 0.040 & 0.140 \\
\hline & $(0.082)$ & $(0.535)$ & $(0.097)$ & $(0.308)$ & $(0.046)$ & $(0.043)$ & $(0.095)$ \\
\hline SGD & -0.027 & -0.366 & 0.074 & 0.102 & -0.150 & 0.075 & -0.153 \\
\hline & $(0.088)$ & $(0.265)$ & $(0.121)$ & $(0.215)$ & $(0.267)$ & $(0.088)$ & $(0.205)$ \\
\hline AUD & $0.264^{* * *}$ & $0.326^{* *}$ & $0.242^{* * *}$ & $0.206^{* * *}$ & -0.209 & $0.415^{* * *}$ & $0.438^{* * *}$ \\
\hline & $(0.080)$ & $(0.153)$ & $(0.044)$ & $(0.057)$ & $(0.351)$ & $(0.052)$ & $0.075)$ \\
\hline MYR & $0.175^{*}$ & 0.345 & -0.108 & -0.001 & 0.378 & 0.000 & 0.056 \\
\hline & $(0.099)$ & $(0.326)$ & $(0.193)$ & $(0.072)$ & $(0.257)$ & $(0.000)$ & $(0.260)$ \\
\hline THB & 0.034 & -0.020 & $2.407^{* * *}$ & $2.713^{* *}$ & -0.073 & -0.073 & -0.088 \\
\hline & $(0.025)$ & $(0.044)$ & $(0.692)$ & $(1.238)$ & $(0.122)$ & $(0.064)$ & $(0.081)$ \\
\hline French & 0.013 & 0.243 & $-0.105^{*}$ & & & & \\
\hline & $(0.030)$ & $0.189)$ & $(0.059)$ & & & & \\
\hline$\Delta[\log$ Res+logEx] & 0.009 & $0.208^{* * *}$ & -0.015 & -0.029 & 0.346 & $0.038^{*}$ & 0.012 \\
\hline & $(0.006)$ & $(0.054)$ & $(0.017)$ & $(0.019)$ & $(0.204)$ & $(0.021)$ & $(0.020)$ \\
\hline Germany & & & & $-0.263^{* *}$ & 0.764 & & \\
\hline & & & & $(0.113)$ & $(0.456)$ & & \\
\hline EUR & & & & & & $0.244 * * *$ & 0.119 \\
\hline & & & & & & $(0.055)$ & $(0.108)$ \\
\hline Constant & $-0.002^{*}$ & -0.004 & -0.001 & 0.002 & -0.006 & 0.001 & -0.001 \\
\hline & $(0.001)$ & $(0.004)$ & $(0.001)$ & $(0.002)$ & $(0.005)$ & $(0.001)$ & $(0.001)$ \\
\hline Observations & 46 & 48 & 48 & 48 & 36 & 48 & 34 \\
\hline R-squared & 0.955 & 0.749 & 0.963 & 0.967 & 0.555 & 0.948 & 0.885 \\
\hline GBP & 0.188 & 0.191 & 0.040 & 0.163 & 0.046 & 0.017 & 0.171 \\
\hline & & & & & & & \\
\hline
\end{tabular}


9.8 Hong Kong dollar (hkd)

\begin{tabular}{|c|c|c|c|}
\hline In swissf & (1) & $(2)$ & (3) \\
\hline & hkd 97-00 & $01-04$ & $05-08$ \\
\hline \multirow[t]{2}{*}{ JPY } & -0.002 & -0.003 & -0.018 \\
\hline & $(0.003)$ & $(0.011)$ & $(0.017)$ \\
\hline \multirow[t]{2}{*}{ USD } & $0.997 * * *$ & -315.466 & $1.071 * * *$ \\
\hline & $(0.018)$ & $(335.352)$ & $(0.046)$ \\
\hline \multirow[t]{2}{*}{ KRW } & 0.004 & -0.001 & 0.011 \\
\hline & $(0.003)$ & $(0.015)$ & $(0.026)$ \\
\hline \multirow[t]{2}{*}{ SGD } & 0.009 & -0.019 & 0.014 \\
\hline & $(0.008)$ & $(0.022)$ & $(0.046)$ \\
\hline \multirow[t]{2}{*}{ AUD } & 0.003 & 0.004 & 0.025 \\
\hline & $(0.007)$ & $(0.006)$ & $(0.019)$ \\
\hline \multirow[t]{2}{*}{ MYR } & -0.005 & 316.470 & 0.007 \\
\hline & $(0.005)$ & $(335.348)$ & $(0.026)$ \\
\hline \multirow[t]{2}{*}{ THB } & -0.004 & 0.018 & -0.011 \\
\hline & $(0.005)$ & $(0.018)$ & $(0.030)$ \\
\hline \multirow[t]{2}{*}{ Germany } & -0.012 & & \\
\hline & $(0.012)$ & & \\
\hline \multirow[t]{2}{*}{$\Delta[\log R e s+\log E x]$} & -0.004 & $-0.015 * *$ & $-0.046^{* *}$ \\
\hline & $(0.005)$ & $(0.007)$ & $(0.020)$ \\
\hline \multirow[t]{2}{*}{ EUR } & & -0.016 & -0.066 \\
\hline & & $(0.014)$ & $(0.041)$ \\
\hline \multirow[t]{2}{*}{ Constant } & 0.000 & -0.000 & 0.000 \\
\hline & $(0.000)$ & $(0.000)$ & $(0.000)$ \\
\hline Observations & 23 & 48 & 30 \\
\hline R-squared & 0.999 & 0.998 & 0.997 \\
\hline GBP & 0.010 & 0.014 & -0.032 \\
\hline
\end{tabular}

\section{* Statistically significant at $\mathbf{. 1 0}$ level \\ ** Statistically significant at $\mathbf{0 5}$ level $* * *$ Statistically significant at .01 level}




\section{Table 10: Extension 5 Monte Carlo Simulations}

In this extension, we tried Monte Carlo studies on fabricated currencies -- some constructed with the monetary authorities leaning halfway against the wind of any fluctuations in EMP, and others constrained more narrowly to remain within a Plus and minus $2.5 \%$ Band -- to see if the technique gives us the right answer.

We use the true path of the euro, dollar and yen (in SDR) over the last 8 years to make up a currency (abbreviated as MCSA for Monte Carlo Simulation) with certain configurations of weights, and then try to see if we can recover these weights with the methodology introduced in this paper.

\subsection{The case of leaning against the wind}

10.1.1 Simulated currency MCSA computed as basket (with weights 1/3 euros, 1/3 dollars and $1 / 3$ yen) valued with the SDR as numeraire:

$\log [M C S A+r w]=(\log [j p y]) / 3+(\log [$ eur $]) / 3+(\log [u s d]) / 3$

\section{Note:}

$\mathrm{rw}$ is a random walk variable which is defined as:

$r w(t)=r w(t-1)+a$

$a$ is a normally distributed random variable and $a \sim N(0,0.03)$

We use the true variance of EMP drawn from some real countries, choosing two representatives: a high variance case from a commodity producer $(\mathrm{PNG})$ and a lowvariance case $(\mathrm{CAD})$. 


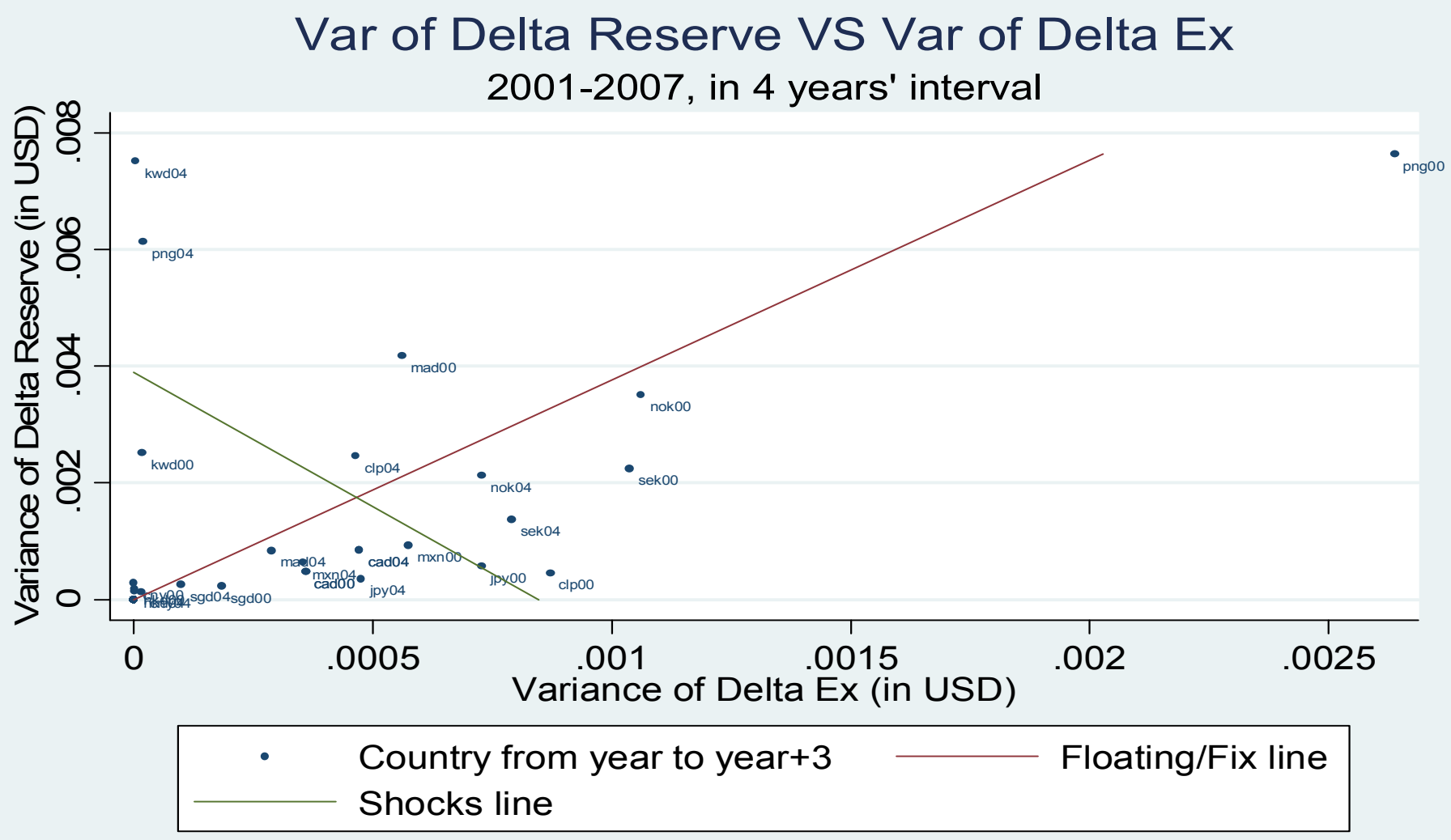

Reserve data: after subtracting off the imputed interest

$<1>$ The Case of PNG:

Regression specification: $\quad D \lg (m c s a)-d \lg (g b p)=x 1 \cdot[\operatorname{dlg}(u s d)-d \lg (g b p)]+x 2$.

$[d \lg ($ eur $)-d \lg (g b p)]+x 3 \cdot[d \lg (j p y)-d \lg (g b p)]+x 0 \cdot\{0.5 * d \lg ($ PNGRes $)+0.5 \operatorname{dlg}(m c s a)\}$

10.1 Leaning against the wind, around a basket ( $1 / 3$ euros, $1 / 3$ dollars and $1 / 3$ yen) Calibrated by PNG reserve changes

\begin{tabular}{|l|l|l|l|l|l|l|}
\hline & $(1)$ & $(2)$ & $(3)$ & $(4)$ & $(5)$ & $(6)$ \\
\hline & In SDR & In SDR & In SDR & Swiss franc & Swiss franc & Swiss franc \\
& $00-07$ & $00-03$ & $04-07$ & $00-07$ & $00-03$ & $04-07$ \\
\hline EUR & $0.290^{* * *}$ & $0.272^{* * *}$ & $0.363^{* * *}$ & $0.278^{* * *}$ & $0.264^{* * *}$ & $0.346^{* * *}$ \\
\hline & $(0.039)$ & $(0.041)$ & $(0.119)$ & $(0.034)$ & $(0.032)$ & $(0.120)$ \\
\hline JPY & $0.320^{* * *}$ & $0.334^{* * *}$ & $0.290^{* * *}$ & $0.320^{* * *}$ & $0.334^{* * * *}$ & $0.288^{* * *}$ \\
\hline & $(0.039)$ & $(0.054)$ & $(0.060)$ & $(0.040)$ & $(0.056)$ & $(0.062)$ \\
\hline USD & $0.387^{* * *}$ & $0.385^{* * *}$ & $0.374^{* * *}$ & $0.396^{* * *}$ & $0.389^{* * *}$ & $0.397^{* * *}$ \\
\hline & $(0.035)$ & $(0.047)$ & $(0.062)$ & $(0.035)$ & $(0.048)$ & $(0.061)$ \\
\hline$\Delta[\operatorname{logRes}+\log \mathrm{Ex}] / 2$ & -0.024 & -0.014 & -0.043 & -0.015 & -0.010 & -0.031 \\
\hline & $(0.021)$ & $(0.030)$ & $(0.037)$ & $(0.020)$ & $(0.030)$ & $(0.036)$ \\
\hline Constant & -0.000 & -0.001 & 0.000 & -0.000 & -0.001 & 0.000 \\
\hline & $(0.001)$ & $(0.001)$ & $(0.001)$ & $(0.001)$ & $(0.001)$ & $(0.001)$ \\
\hline Observations & 89 & 48 & 41 & 89 & 48 & 41 \\
\hline R-squared & 0.849 & 0.874 & 0.820 & 0.847 & 0.874 & 0.816 \\
\hline GBP & 0.003 & 0.009 & -0.026 & 0.006 & 0.013 & -0.030 \\
\hline
\end{tabular}


$<2>$ The Case of CAD

Regression specification:

$D \lg (m c s a)-d \lg (g b p)=x 1 \cdot[d \lg (u s d)-d \lg (g b p)]+x 2 \cdot[d \lg ($ eur $)-d \lg (g b p)]+x 3 \cdot[\operatorname{dlg}(j p y)$

$-d \lg (g b p)]+x 0 \cdot\{0.5 * \operatorname{dlg}(C A D R e s)+0.5 \operatorname{dlg}(m c s a)\}$

10.2 Leaning against the wind around a basket (1/3 euros, 1/3 dollars and 1/3 yen)

Calibrated by CAD reserve changes

\begin{tabular}{|c|c|c|c|c|c|c|}
\hline & (1) & (2) & (3) & (4) & (5) & (6) \\
\hline & $\begin{array}{l}\text { In SDR } \\
00-07\end{array}$ & $\begin{array}{l}\text { In SDR } \\
00-03\end{array}$ & $\begin{array}{l}\text { In SDR } \\
04-07\end{array}$ & $\begin{array}{l}\text { Swiss franc } \\
00-07\end{array}$ & $\begin{array}{l}\text { Swiss franc } \\
00-03\end{array}$ & $\begin{array}{l}\text { Swiss franc } \\
04-07\end{array}$ \\
\hline \multirow[t]{2}{*}{ EUR } & $0.295 * * *$ & $0.291 * * *$ & $0.347 * * *$ & $0.410 * * *$ & $0.389 * * *$ & $0.468 * * *$ \\
\hline & $(0.031)$ & $(0.036)$ & $(0.099)$ & $(0.045)$ & $(0.071)$ & $(0.101)$ \\
\hline \multirow[t]{2}{*}{ JPY } & $0.316^{* * *}$ & $0.330 * * *$ & $0.287 * * *$ & $0.306^{* * *}$ & $0.307 * * *$ & $0.308 * * *$ \\
\hline & $(0.034)$ & $(0.043)$ & $(0.050)$ & $(0.034)$ & $(0.045)$ & $(0.052)$ \\
\hline \multirow[t]{2}{*}{ USD } & $0.364 * * *$ & $0.383 * * *$ & $0.334 * * *$ & $0.278^{* * *}$ & $0.322 * * *$ & $0.202 * * *$ \\
\hline & $(0.033)$ & $(0.044)$ & $(0.055)$ & $(0.041)$ & $(0.052)$ & $(0.073)$ \\
\hline \multirow[t]{2}{*}{$\Delta[\log \mathrm{Res}+\log \mathrm{Ex}] / 2$} & $0.242^{* * *}$ & $0.263 * *$ & $0.249^{* * *}$ & $0.197 * * *$ & $0.171 * *$ & $0.229 * * *$ \\
\hline & $(0.053)$ & $(0.121)$ & $(0.062)$ & $(0.041)$ & $(0.082)$ & $(0.053)$ \\
\hline \multirow[t]{2}{*}{ Constant } & -0.001 & -0.001 & -0.000 & -0.001 & -0.001 & -0.001 \\
\hline & $(0.001)$ & $(0.001)$ & $(0.001)$ & $(0.001)$ & $(0.001)$ & $(0.001)$ \\
\hline Observations & 90 & 48 & 42 & 90 & 48 & 42 \\
\hline R-squared & 0.877 & 0.889 & 0.867 & 0.879 & 0.887 & 0.876 \\
\hline GBP & 0.025 & -0.004 & 0.031 & 0.007 & -0.018 & 0.022 \\
\hline
\end{tabular}

10.1.2 Simulated currency MCSA with dollar peg, valued with SDR as numeraire:

$\log [M C S A+r w]=\log [u s d]$

note: $\mathrm{rw}$ is a random walk variable, defined as: $r w(t)=r w(t-1)+a$

$a$ is a normally distributed random variable and $a \sim \mathrm{N}(0,0.03)$

$<1>$ The Case of PNG:

Regression specification: $\quad D \lg (m c s a)-d \lg (g b p)=x 1 \cdot[d \lg (u s d)-d \lg (g b p)]+x 2$.

$[d \lg ($ eur $)-d \lg (g b p)]+x 3 \cdot[d \lg (j p y)-d \lg (g b p)]+x 0 \cdot\{0.5 * d \lg (P N G R e s)+0.5 d \lg (m c s a)\}$

10.3 Leaning against the wind, around a dollar peg;

Calibrated by PNG reserve changes

\begin{tabular}{|c|c|c|c|c|c|c|}
\hline & $(1)$ & $(2)$ & (3) & (4) & $(5)$ & $(6)$ \\
\hline & $\begin{array}{l}\text { In SDR } \\
00-07\end{array}$ & $\begin{array}{l}\text { In SDR } \\
00-03\end{array}$ & $\begin{array}{l}\text { In SDR } \\
04-07\end{array}$ & $\begin{array}{l}\text { Swiss franc } \\
00-07\end{array}$ & $\begin{array}{l}\text { Swiss franc } \\
00-03\end{array}$ & $\begin{array}{l}\text { Swiss franc } \\
04-07\end{array}$ \\
\hline \multirow[t]{2}{*}{ EUR } & -0.011 & $-0.014^{*}$ & 0.001 & $-0.015 * *$ & $-0.017 * *$ & -0.004 \\
\hline & $(0.008)$ & $(0.008)$ & $(0.024)$ & $(0.007)$ & $(0.007)$ & $(0.025)$ \\
\hline \multirow[t]{2}{*}{ JPY } & -0.006 & -0.002 & -0.014 & -0.005 & -0.002 & -0.015 \\
\hline & $(0.008)$ & $(0.010)$ & $(0.013)$ & $(0.008)$ & $(0.010)$ & $(0.014)$ \\
\hline \multirow[t]{2}{*}{ USD } & $1.017 * * *$ & $1.015^{* * *}$ & $1.016^{* * *}$ & $1.019 * * *$ & $1.016^{* * *}$ & $1.023^{* * *}$ \\
\hline & $(0.007)$ & $(0.010)$ & $(0.013)$ & $(0.008)$ & $(0.010)$ & $(0.014)$ \\
\hline \multirow[t]{2}{*}{$\Delta[\log \operatorname{Res}+\log \mathrm{Ex}] / 2$} & $-0.007^{*}$ & -0.005 & -0.013 & -0.006 & -0.004 & -0.011 \\
\hline & $(0.004)$ & $(0.006)$ & $(0.008)$ & $(0.004)$ & $(0.006)$ & $(0.008)$ \\
\hline \multirow[t]{2}{*}{ Constant } & -0.000 & -0.000 & 0.000 & -0.000 & -0.000 & 0.000 \\
\hline & $(0.000)$ & $(0.000)$ & $(0.000)$ & $(0.000)$ & $(0.000)$ & $(0.000)$ \\
\hline
\end{tabular}




\begin{tabular}{|l|l|l|l|l|l|l|}
\hline Observations & 89 & 48 & 41 & 89 & 48 & 41 \\
\hline R-squared & 0.996 & 0.996 & 0.995 & 0.995 & 0.996 & 0.995 \\
\hline GBP & -0.000 & 0.001 & -0.003 & 0.001 & 0.002 & -0.004 \\
\hline
\end{tabular}

$<2>$ The Case of CAD:

Regression specification: $\quad D \lg (m c s a)-d \lg (g b p)=x 1 \cdot[\operatorname{dlg}(u s d)-d \lg (g b p)]+x 2$.

$[d \lg ($ eur $)-d \lg (g b p)]+x 3 \cdot[d \lg (j p y)-d \lg (g b p)]+x 0 \cdot\{0.5 * d \lg (C A D R e s)+0.5 \operatorname{dlg}(m c s a)\}$

10.4 Leaning against the wind, around a dollar peg

Calibrated by CAD reserve changes

\begin{tabular}{|l|l|l|l|l|l|l|}
\hline & $(1)$ & $(2)$ & $(3)$ & $(4)$ & $(5)$ & $(6)$ \\
\hline & In SDR & In SDR & In SDR & Swiss franc & Swiss franc & Swiss franc \\
& $00-07$ & $00-03$ & $04-07$ & $00-07$ & $00-03$ & $04-07$ \\
\hline EUR & -0.006 & -0.013 & 0.008 & 0.012 & -0.003 & 0.031 \\
\hline & $(0.008)$ & $(0.010)$ & $(0.024)$ & $(0.011)$ & $(0.016)$ & $(0.025)$ \\
\hline JPY & -0.001 & -0.001 & -0.006 & -0.002 & -0.002 & -0.002 \\
\hline & $(0.008)$ & $(0.012)$ & $(0.013)$ & $(0.008)$ & $(0.010)$ & $(0.013)$ \\
\hline USD & $1.003^{* * *}$ & $1.011^{* * *}$ & $0.994^{* * *}$ & $0.989 * * *$ & $1.004^{* * *}$ & $0.968^{* * *}$ \\
\hline & $(0.009)$ & $(0.012)$ & $(0.016)$ & $(0.011)$ & $(0.014)$ & $(0.019)$ \\
\hline$[\operatorname{logRes}+\operatorname{logEx}] / 2$ & $0.031^{* * *}$ & 0.010 & $0.042^{* * *}$ & $0.031^{* * *}$ & 0.014 & $0.043^{* * *}$ \\
\hline Constant & $(0.011)$ & $(0.029)$ & $(0.013)$ & $(0.009)$ & $(0.016)$ & $(0.011)$ \\
\hline & -0.000 & -0.000 & -0.000 & -0.000 & -0.000 & -0.000 \\
\hline Observations & $(0.000)$ & $(0.000)$ & $(0.000)$ & $(0.000)$ & $(0.000)$ & $(0.000)$ \\
\hline R-squared & 90 & 48 & 42 & 90 & 48 & 42 \\
\hline GBP & 0.996 & 0.996 & 0.995 & 0.996 & 0.996 & 0.995 \\
\hline
\end{tabular}

10.2 The case of a Plus and minus $2.5 \%$ Target Zones with random walk

10.2.1 Simulated currency MCSA computed as basket (with weights 1/3 euros, 1/3 dollars and $1 / 3$ yen), valued with the SDR as numeraire:

$\log [M C S A+r w]=(\log [j p y]) / 3+(\log [$ eur $]) / 3+(\log [u s d]) / 3$

\section{Note:}

rw is a random walk variable: $\quad r w(t)=r w(t-1)+a, \quad a \sim N(0,0.01)$

with a plus or minus $2.5 \%$ credible band.

The defined currency is illustrated in the following graph, Figure 3.

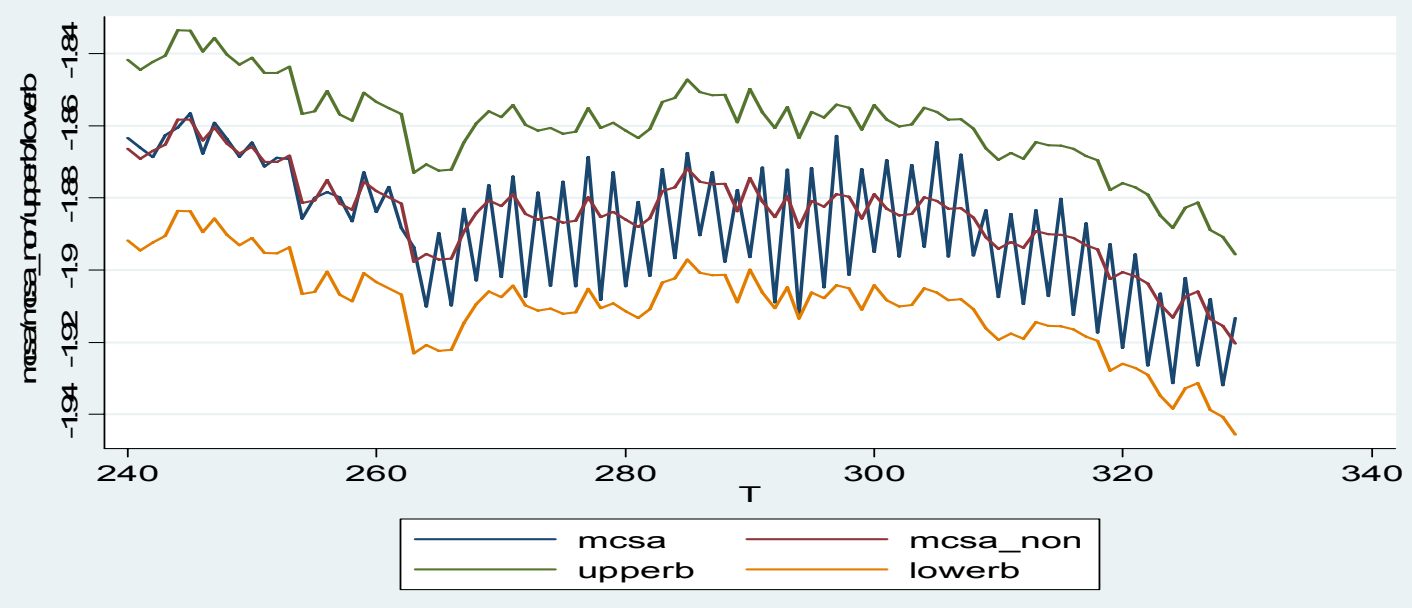

Figure 3 
Notes:

1. mcsa_non demonstrates a perfect peg with USD, EUR and JPY.

2. upperb is the upper $2.5 \%$ bound and lowerb is the lower bound.

3. mcsa is the makeup currency with combination of a random walk and the perfect peg.

We use the EMP values of some real countries to recover the currency weights and also try two types of countries: a high variance case (PNG) and a low-variance case (CAD).

$<1>$ The Case of PNG:

We then try to recover the weights.

Regression specification:

$D \lg (m c s a)-d \lg (g b p)=x 1 \cdot[d \lg (u s d)-d \lg (g b p)]+x 2 \cdot[d \lg ($ eur $)-\operatorname{dlg}(g b p)]+x 3 \cdot[d \lg (j p y)$

$-d l g(g b p)]+x 0 \cdot\{d \lg (P N G E M P)\}$

10.5 Target Zones with random walk, around basket (with weights $1 / 3$ euros, $1 / 3$ dollars and $1 / 3$ yen) Calibrated by PNG EMP changes, valued with the SDR as numeraire:

\begin{tabular}{|c|c|c|c|c|c|c|}
\hline & $(1)$ & $(2)$ & (3) & (4) & $(5)$ & (6) \\
\hline & $\begin{array}{l}\text { In SDR } \\
00-07\end{array}$ & $\begin{array}{l}\text { In SDR } \\
00-03\end{array}$ & $\begin{array}{l}\text { In SDR } \\
04-07\end{array}$ & $\begin{array}{l}\text { Swiss franc } \\
00-07\end{array}$ & $\begin{array}{l}\text { Swiss franc } \\
00-03\end{array}$ & $\begin{array}{l}\text { Swiss franc } \\
04-07\end{array}$ \\
\hline \multirow[t]{2}{*}{ EUR } & $0.323 * * *$ & $0.296 * * *$ & $0.426 * *$ & $0.347 * * *$ & $0.323 * * *$ & $0.469 * *$ \\
\hline & $(0.040)$ & $(0.043)$ & $(0.172)$ & $(0.037)$ & $(0.039)$ & $(0.203)$ \\
\hline \multirow[t]{2}{*}{ JPY } & $0.287 * * *$ & $0.301 * * *$ & $0.252 * * *$ & $0.284 * * *$ & $0.293 * * *$ & $0.262 * * *$ \\
\hline & $(0.034)$ & $(0.044)$ & $(0.067)$ & $(0.035)$ & $(0.044)$ & $(0.060)$ \\
\hline \multirow[t]{2}{*}{ USD } & $0.343 * * *$ & $0.350 * * *$ & 0.318 & $0.323 * * *$ & $0.332 * * *$ & 0.268 \\
\hline & $(0.048)$ & $(0.056)$ & $(0.197)$ & $(0.048)$ & $(0.054)$ & $(0.188)$ \\
\hline \multirow[t]{2}{*}{$\Delta[\log \mathrm{PNGEMP}]$} & $0.040 * *$ & $0.044 * *$ & 0.027 & $0.045 * *$ & $0.049 * *$ & 0.063 \\
\hline & $(0.019)$ & $(0.020)$ & $(0.267)$ & $(0.017)$ & $(0.018)$ & $(0.153)$ \\
\hline \multirow[t]{2}{*}{ Constant } & -0.000 & 0.000 & -0.000 & -0.000 & 0.000 & -0.000 \\
\hline & $(0.001)$ & $(0.001)$ & $(0.001)$ & $(0.001)$ & $(0.001)$ & $(0.002)$ \\
\hline Observations & 89 & 48 & 41 & 89 & 48 & 41 \\
\hline R-squared & 0.831 & 0.881 & 0.760 & 0.833 & 0.884 & 0.761 \\
\hline GBP & 0.047 & 0.053 & 0.004 & 0.046 & 0.051 & 0.000 \\
\hline
\end{tabular}


$<2>$ The Case of CAD:

Regression specification:

$D \lg (m c s a)-d \lg (g b p)=x 1 \cdot[d \lg (u s d)-d \lg (g b p)]+x 2 \cdot[d \lg ($ eur $)-d \lg (g b p)]+x 3 \cdot[d \lg (j p y)$

$-d \lg (g b p)]+x 0 \cdot\{d l g(C A D E M P)\}$

\subsection{Target Zones with random walk around basket (weights $1 / 3$ euros, $1 / 3$ dollars and $1 / 3$ yen) \\ Calibrated by CAD EMP reserve changes}

\begin{tabular}{|c|c|c|c|c|c|c|}
\hline & (1) & (2) & (3) & (4) & (5) & (6) \\
\hline & $\begin{array}{l}\text { In SDR } \\
00-07\end{array}$ & $\begin{array}{l}\text { In SDR } \\
00-03\end{array}$ & $\begin{array}{l}\text { In SDR } \\
04-07\end{array}$ & $\begin{array}{l}\text { Swiss franc } \\
00-07\end{array}$ & $\begin{array}{l}\text { Swiss franc } \\
00-03\end{array}$ & $\begin{array}{l}\text { Swiss franc } \\
04-07\end{array}$ \\
\hline \multirow[t]{2}{*}{ EUR } & $0.424 * * *$ & $0.451 * * *$ & 0.248 & $0.619 * * *$ & $0.722 * * *$ & 0.341 \\
\hline & $(0.120)$ & $(0.152)$ & $(0.207)$ & $(0.151)$ & $(0.224)$ & $(0.219)$ \\
\hline \multirow[t]{2}{*}{ JPY } & $0.409 * * *$ & $0.456^{* * *}$ & $0.375 * *$ & $0.398 * * *$ & $0.403 * * *$ & $0.390 * *$ \\
\hline & $(0.100)$ & $(0.137)$ & $(0.157)$ & $(0.096)$ & $(0.127)$ & $(0.150)$ \\
\hline \multirow[t]{2}{*}{ USD } & 0.043 & -0.118 & 0.297 & -0.118 & -0.267 & 0.177 \\
\hline & $(0.153)$ & $(0.238)$ & $(0.183)$ & $(0.165)$ & $(0.254)$ & $(0.198)$ \\
\hline \multirow[t]{2}{*}{$\Delta[\log \mathrm{CADEMP}]$} & $0.275 * *$ & $0.422^{*}$ & 0.132 & $0.321 * * *$ & $0.427 * *$ & 0.177 \\
\hline & $(0.122)$ & $(0.248)$ & $(0.164)$ & $(0.106)$ & $(0.199)$ & $(0.147)$ \\
\hline \multirow[t]{2}{*}{ Constant } & -0.001 & -0.001 & -0.001 & -0.001 & -0.001 & -0.001 \\
\hline & $(0.002)$ & $(0.004)$ & $(0.003)$ & $(0.002)$ & $(0.004)$ & $(0.003)$ \\
\hline Observations & 90 & 48 & 42 & 90 & 48 & 42 \\
\hline R-squared & 0.377 & 0.338 & 0.526 & 0.404 & 0.368 & 0.538 \\
\hline GBP & 0.124 & 0.210 & 0.080 & 0.101 & 0.141 & 0.092 \\
\hline
\end{tabular}

10.2.2 Simulated currency MCSA around dollar peg, valued with SDR as numeraire: $\log [M C S A+r w]=\log [u s d]$

Note: $r w$ is a random walk variable: $\quad r w(t)=r w(t-1)+a, \quad a \sim N(0,0.01)$ with a Plus and minus $2.5 \%$ credible band

$<1>$ Case of PNG:

Regression specification:

$D \lg (m c s a)-d \lg (g b p)=x 1 \cdot[d \lg (u s d)-d \lg (g b p)]+x 2 \cdot[d \lg ($ eur $)-d \lg (g b p)]+x 3 \cdot[d \lg (j p y)$

$-d \lg (g b p)]+x 0 \cdot\{d \lg (P N G E M P)\}$ 


\subsection{Target Zones with random walk, around a dollar peg}

Calibrated by PNG EMP changes

\begin{tabular}{|l|l|l|l|l|l|l|}
\hline & $(1)$ & $(2)$ & $(3)$ & $(4)$ & $(5)$ & $(6)$ \\
\hline & In SDR & In SDR & In SDR & Swiss franc & Swiss franc & Swiss franc \\
& $00-07$ & $00-03$ & $04-07$ & $00-07$ & $00-03$ & $04-07$ \\
\hline EUR & -0.009 & -0.033 & 0.087 & 0.010 & -0.012 & 0.127 \\
\hline & $(0.034)$ & $(0.035)$ & $(0.159)$ & $(0.032)$ & $(0.031)$ & $(0.188)$ \\
\hline JPY & -0.040 & -0.025 & -0.076 & -0.042 & -0.031 & -0.066 \\
\hline & $(0.029)$ & $(0.035)$ & $(0.061)$ & $(0.030)$ & $(0.036)$ & $(0.055)$ \\
\hline USD & $1.008^{* * *}$ & $1.014 * * *$ & $0.985^{* * *}$ & $0.992^{* * *}$ & $1.000^{* * *}$ & $0.939^{* * *}$ \\
\hline & $(0.042)$ & $(0.045)$ & $(0.182)$ & $(0.042)$ & $(0.044)$ & $(0.173)$ \\
\hline [logPNGEMP] & $0.031^{* *}$ & $0.034 * *$ & 0.024 & $0.035^{* *}$ & $0.038^{* *}$ & 0.057 \\
\hline Constant & $(0.015)$ & $(0.016)$ & $(0.245)$ & $(0.014)$ & $(0.015)$ & $(0.140)$ \\
\hline & -0.000 & 0.000 & -0.000 & -0.000 & 0.000 & -0.000 \\
\hline Observations & $(0.001)$ & $(0.001)$ & $(0.001)$ & $(0.001)$ & $(0.001)$ & $(0.001)$ \\
\hline R-squared & 89 & 48 & 41 & 89 & 48 & 41 \\
\hline GBP & 0.921 & 0.948 & 0.890 & 0.922 & 0.949 & 0.891 \\
\hline
\end{tabular}

$<2>$ Case of CAD:

Regression specification: $\quad D \lg (m c s a)-d \lg (g b p)=x 1 \cdot[d \lg (u s d)-d \lg (g b p)]+x 2$.

$[d \lg (e u r)-d \lg (g b p)]+x 3 \cdot[d \lg (j p y)-d \lg (g b p)]+x 0 \cdot\{d \lg (C A D E M P)\}$

\subsection{Target Zones with random walk, around a dollar peg}

Calibrated by CAD EMP changes

\begin{tabular}{|l|l|l|l|l|l|l|}
\hline & $(1)$ & $(2)$ & $(3)$ & $(4)$ & $(5)$ & $(6)$ \\
\hline & In SDR & In SDR & In SDR & Swiss franc & Swiss franc & Swiss franc \\
& $00-07$ & $00-03$ & $04-07$ & $00-07$ & $00-03$ & $04-07$ \\
\hline EUR & -0.001 & -0.020 & 0.086 & 0.005 & -0.002 & 0.071 \\
\hline & $(0.033)$ & $(0.034)$ & $(0.107)$ & $(0.044)$ & $(0.049)$ & $(0.111)$ \\
\hline JPY & -0.035 & -0.019 & -0.068 & -0.033 & -0.016 & -0.073 \\
\hline & $(0.029)$ & $(0.035)$ & $(0.056)$ & $(0.030)$ & $(0.035)$ & $(0.055)$ \\
\hline USD & $1.028^{* * *}$ & $1.031^{* * *}$ & $1.016^{* * *}$ & $1.013^{* * *}$ & $1.014 * * *$ & $1.023^{* * *}$ \\
\hline & $(0.039)$ & $(0.049)$ & $(0.073)$ & $(0.041)$ & $(0.053)$ & $(0.063)$ \\
\hline$\Delta[\log$ CADEMP $]$ & -0.045 & -0.035 & -0.066 & 0.005 & 0.020 & -0.029 \\
\hline Constant & $(0.052)$ & $(0.067)$ & $(0.078)$ & $(0.039)$ & $(0.044)$ & $(0.066)$ \\
\hline & 0.000 & 0.000 & -0.000 & -0.000 & 0.000 & -0.000 \\
\hline Observations & $(0.001)$ & $(0.001)$ & $(0.001)$ & $(0.001)$ & $(0.001)$ & $(0.001)$ \\
\hline R-squared & 90 & 48 & 42 & 90 & 48 & 42 \\
\hline GBP & 0.918 & 0.944 & 0.891 & 0.918 & 0.944 & 0.889 \\
\hline
\end{tabular}

* Statistically significant at $\mathbf{. 1 0}$ level

** Statistically significant at $\mathbf{. 0 5}$ level

$* * *$ Statistically significant at .01 level 